\title{
ESTABELECIMENTO DO MOMENTO DE IRRIGAÇÃO COM BASE NA TENSÃO DA ÁGUA NO SOLO PARA A CULTURA DO FEIJOEIRO
}

\author{
SEBASTIÃO FRANCISCO FIGUERÊDO \\ Engenheiro Agricola
}

Orientador: Prof. Dr. José Antonio Frizzone

Dissertação apresentada à Escola Superior de Agricultura "Luiz de Queiroz", Universidade de São Paulo, para obtenção do título de Mestre em Agronomia, Área de Concentração: Irrigação e Drenagem.

PIRACICABA

Estado de São Paulo - Brasil

Fevereiro -1998 
Dados Internacionais de Catalogação na Publicação (CIP) DIVISÃo DE BIBLIOTECA E DOCUMENTAÇĀO - Campus "Luiz de Queiroz"/USP

Figuerêdo, Sebastião Francisco

Estabelecimento do momento de irrigação com base na tensão da água no solo

para a cultura do feijoeiro / Sebastião Francisco Figuerêdo. - - Piracicaba, 1998.

$94 \mathrm{p}$.

Dissertação (mestrado) - - Escola Superior de Agricultura Luiz de Queiroz, 1998. Bibliografia.

1. Balanço hidrico 2. Disponiblidade hidrica 3. Feijão irrigado 4. Física do solo 5. Relação solo-água I. Título

CDD 635.652 


\title{
ESTABELECIMENTO DO MOMENTO DE IRRIGAÇÃO COM BASE NA TENSÃO DA ÁGUA NO SOLO PARA A CULTURA DO FEIJOEIRO
}

\author{
SEBASTIÃO FRANCISCO FIGUERÊDO
}

Aprovada em: 04.04.1998

Comissão julgadora:

Prof. Dr. José Antonio Frizzone

ESALQ/USP

Prof. Dr. Antônio Melhem Saad IPT/SP

Prof. Dr. João Carlos Cury Saad FCA/UNESP

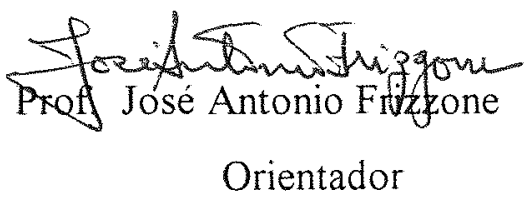




\section{PRECE DE CÁRITAS}

"DEUS, Nosso Pai, que sois todo poder e bondade, dai força àquele que passa pela provação; dai luz àquele que procura a verdade, pondo no coração do homem a compaixão e a caridade. Deus, dai ao viajor a estrela guia; ao aflito a consolação, ao doente o repouso. Pai, dai ao culpado o arrependimento; ao espírito a verdade; à criança o guia, ao órfão o pai. Senhor, que a vossa bondade se estenda sobre tudo que criastes. Piedade Senhor para aqueles que não vos conhece, esperança para aqueles que sofrem. Que a vossa bondade permita hoje aos espíritos consoladores espalharem por toda parte a paz, a esperança e a fé. Deus, um raio, uma faísca do vosso amor pode abrasar a terra. Deixa-nos beber nas fontes dessa bondade fecunda e infinita e todas as lágrimas secarão, todas as dores acalmarse-ão. Um só coração, um só pensamento subirá até Vós com um grito de reconhecimento e amor. E como Moisés sobre a montanha, nós vos esperamos de braços abertos, oh! Poder... oh! Beleza... oh! Bondade... oh! Perfeição, e queremos de alguma forma alcançar a vossa misericórdia. Deus, dai-nos a força de ajudar o progresso a fim de subirmos até Vós; Dai-nos a caridade pura; dai-nos a fé e a razão; dai-nos a simplicidade que fará de nossas almas, o espelho onde deve refletir a Vossa Santa e pura imagem". 
Aos meus pais JOÃO (in memorian) e ETELVINA, pelos esforços na formação dos filhos por me ensinarem com amor e carinho os bons caminhos da vida.

Dedico

Aos meus irmãos, irmãs e demais membros de minha familia, pelo incentivo e apoio, que justificam qualquer sacrificio. 


\section{AGRADECIMENTOS}

A Deus pela fé, força e coragem no decorrer do curso

Ao prof. Dr. José Antônio Frizzone, pela segura orientação, por sua compreensão, dedicação e pela amizade.

Aos Pesqusadores do CPAC/EMBRAPA, Jamil Macedo e Maria Alice dos Santos Oliveira por abrir-me a oportunidade de realilizar esse curso.

Ao Consultor Dr. Kazuo Miyazawa do convênio JICA-EMBRAPA, que participou desse projeto. Essa dissertação é em grande parte, resultado de um árduo trabalho de campo e laboratório que compartilhamos.

À Empresa Brasileira de Pesquisa Agropecuária - EMBRAPA, através do Centro de Pesquisa Agropecuária dos Cerrados - CPAC, pelo apoio na realização do projeto de pesquisa.

À Comissão de Pós-graduação em Irrigação e Drenagem do Departamento de Engenharia Rural (DER) da Escola Superior de Agricultura "Luiz de Queiroz", pela oportunidade da realização do curso de mestrado.

Aos professores, Marcos Vinícios Folegatti, Décio Eugênio Cruciani, Tarley Arriel Botrel, Sérgio Nascimento Duarte e Rubens Duarte Coelho, pelos ensimentos.

Ao colega Éder João Pozzebon pelo auxílio na análise dos dados, elaboração de gráficos, tabelas, digitação do texto e que não mediu esforços, numa convivência amiga e Adriana Ramos pelo estímulo, incentivo e amizade.

Aos colegas do curso de pós-graduação em Irrigação e Drenagem que mostraramme que o percurso que conduziu a conclusão desse trabalho significa, sobretudo, a descoberta de como é importante a ajuda. 
À Coordenação de Aperfeiçoamento de Pessoal de Nível Superior (CAPES) pelo apoio financeiro.

À Professora do DME/ESALQ Maria Isalina Ferreira Alves, ao Pesquisador do CPAC/EMBRAPA Antônio Carlos Gomes e ao colega Anderson Soares Pereira pelo apoio na análise estatística.

Às bibliotecárias Kátia M. de Andrade Ferraz e Eliana M. Garcia Sabino, ESALQ, pela revisão das referências bibliográficas.

Aos pesquisadores, Juscelino Antônio de Azevedo conselheiro de pos-graduação, Antônio Fernando Guerra que colaborou com a metodologia do projeto, Jorge César dos Anjos Antonini procurador, Euzébio Medrado de Silva e Lucilene Maria de Andrade na condusão da pesquisa.

Aos funcionários do CPAC/EMBRAPA, exemplo de coesão e ideal elevado os quais direta ou indiretamente contribuiram para que esse trabalho fosse realizado e especialmente aos pesquisadores Ariovaldo Luchiari Jr., José Roberto Rodrigues Peres, Elias de Freitas Jr. e Alert Rosa Suhet, minha gratidão.

Aos funcionários do Departamento de Engenharia Rural, Vera Lúcia José Miguel, Antônio César de Sousa Rocha, Gilmar Batista Grigolon, Hélio de Toledo Gomes e José Figueiredo pela gentileza no atendimento aos trabalhos de escritório e laboratório.

À Clotilde Maria Batochio Cunha e Ligia Maria Stella pela correção e formatação da dissertação.

Aos técnicos agrícolas do CPAC/EMBRAPA Edmar Augusto dos Santos, Lúcio Feitosa e José Antônio Fernandes da Silva na condução dos trabalhos de Campo. 


\section{SUMÁRIO}

Página

LISTA DE FIGURAS .................................................................. viii

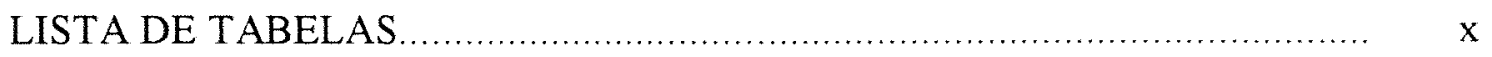

LISTA DE ABREVIATURAS E SÍMBOLOS …..................................... xii

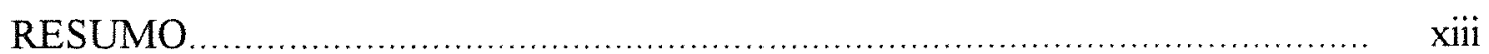

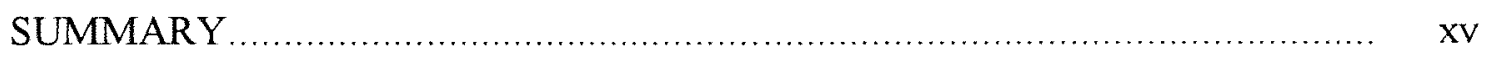

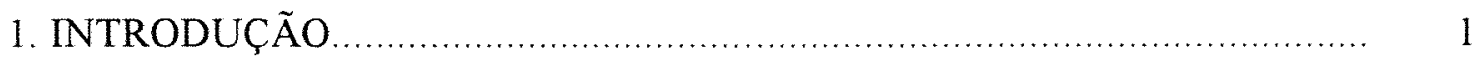

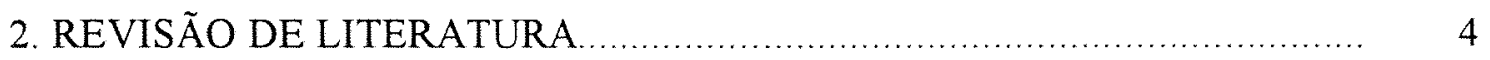

2.1. O cultivo do feijoeiro (Phaseolus vulgaris L.) no Brasil......................... 4

2.2. Irrigação e produtividade do feijoeiro ............................................ 7

2.3. Consumo de água pela cultura do feijoeiro ..................................... 9

2.4. Manejo da irrigação ........................................................... 10

2.5. Instrumentos utilizados na medição da tensão da água no solo ................ 12

3. MATERIAL E MÉTODOS ........................................................... 15

3.1. Descrição da área experimental.............................................. 15

3.2. Delineamento experimental e tratamentos.................................. 15

3.3. Solo e adubação .................................................................. 15

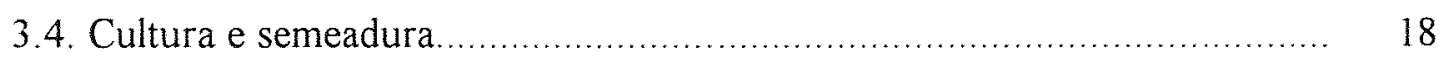

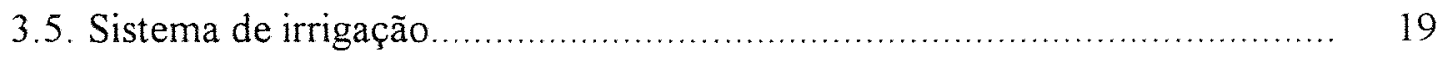

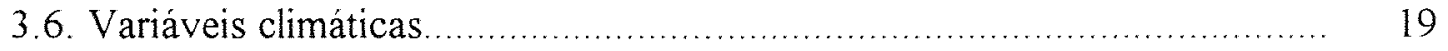

3.7. Controle das irrigações............................................................. 21

3.8. Observações fenológicas.......................................................... 25

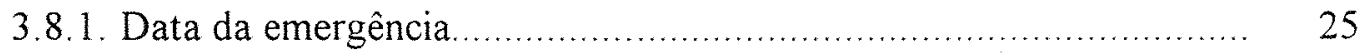

3.8.2. Data do início da floração .............................................. 26

3.8.3. Data do início do enchimento de vagens .............................. 26

3.8.4. Data do início da maturação ................................................ 26

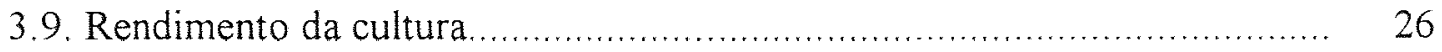


3.10. Componentes da produção........................................................... 28

3.10.1. Número de vagens por planta........................................... 28

3.10.2. Número de grãos por vagens................................................ 28

3.10.3. Peso de 100 grãos............................................................... 28

3.11. Eficiência de uso da água................................................................ 28

3.12. Análise estatística .......................................................................... 28

3.12.1. Análise exploratória dos dados ............................................... $\quad 30$

3.12.1.1. Teste de homogeneidade de variâncias....................................... 31

3.12.1.2. Análise gráfica dos resíduos..................................................... 31

3.12.1.3. Diagrama de "ramos e folhas".............................................. 32

4. RESULTADOS E DISCUSSÃO …...................................................... 33

4.1. Resultados gerais do experimento .................................................. 33

4.2. Análise estatística ....................................................................... 39

4.2.1. Análise exploratória dos dados............................................... 39

4.2.2. Análise da variância e de regressão.............................................. 40

4.2.2.1. Altura de plantas...................................................... 41

4.2.2.2. Número de vagens por planta...................................... 43

4.2.2.3. Número de grãos por vagem........................................ 45

4.2.2.4. Peso de 100 grãos.................................................... 48

4.2.2.5. Rendimento de grãos............................................... 51

4.2.2.6. Eficiência de uso da água............................................. 53

4.2.2.7. Número de irrigações aplicadas.................................... 56

4.2.2.8. Lâmina total de água.............................................. 58

4.2.2.9. Rendimento de grãos em função das lâminas totais.......... 61

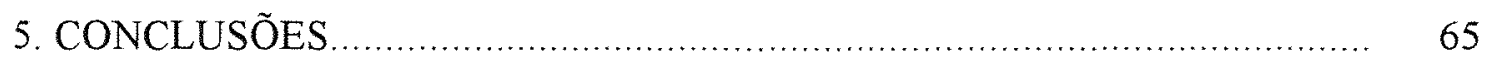

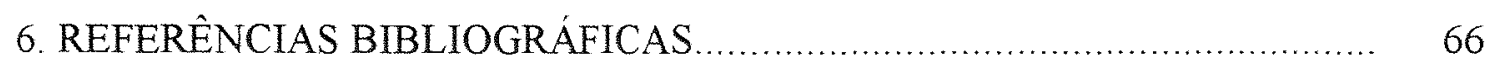

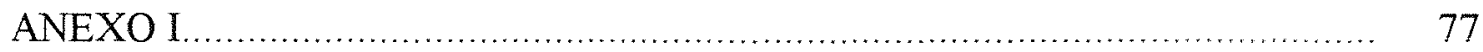

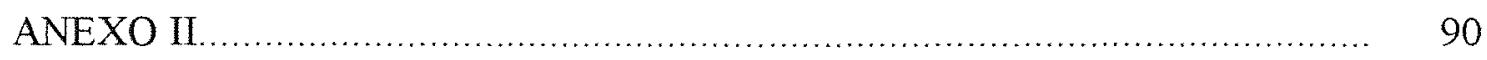

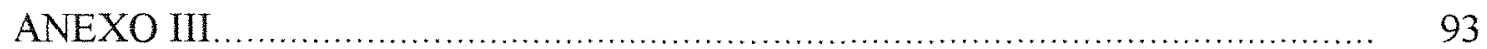




\section{LISTA DE FIGURAS}

Página

1 Representação esquemática do experimento.................................. 16

2 Curvas de retenção da água no solo.......................................... 18

$3 \quad$ Sistema de irrigação utilizado.................................................... 20

$4 \quad$ Vista geral do experimento com a cultura do feijoeiro $\ldots \ldots \ldots \ldots \ldots \ldots \ldots \ldots \ldots \ldots \ldots$

5 Bateria de tensiômetros e medidor de resistência elétrica em bloco de gesso.

6 Bloco de gesso (Bouyoucos) utilizado na medição do teor de água no solo

$7 \quad$ Curva de calibração de blocos de gesso.......................................... 25

$8 \quad$ Média dos 3 anos das fases fenológicas da cultura ............................. 27

9 Variação temporal da tensão da água no solo (10 DAS=03/06/1988), obtidas por tensiômetros, para os tratamentos de $36 \mathrm{kPa}$ (T1), $49 \mathrm{KPa}$ (T2) e $68 \mathrm{kPa}(\mathrm{T} 3)$, com as respectivas lâminas de água aplicadas e limite superior para início da irrigação, para o ano de 1988.

10 Variação temporal da tensão da água no solo (10 DAS=03/06/1988)., obtidas por blocos de gesso, para os tratamentos de $154 \mathrm{kPa}$ (T4), $361 \mathrm{kPa}$ (T5) e $917 \mathrm{kPa}$ (T6), com as respectivas lâminas de água aplicadas e limite superior para início da irrigação, para o ano de 1988.

11 Altura de planta na colheita em função da tensão da água no solo .............. 42

12 Número de vagem por planta em função da tensão da água no solo........... 45

13 Número de grãos por vagem em função da tensão da água no solo $\ldots . . . . . . . . .47$

14 Peso de 100 grãos em função da tensão da água no solo .......................... 49

15 Rendimento de grãos em $\mathrm{kg} \cdot \mathrm{ha}^{-1}$ em função da tensão da água no solo....... 53 
16 Eficiência de uso da água em função da tensão da água no solo.

17 Número total de irrigações em função da tensão da água no solo para os anos de 1988,1990 e 1991

18 Lâmina total de água (irrigação e precipitação) em função da tensão da água no solo para os anos de 1988, 1990 e 1991 .

19 Lâminas totais em função da tensão da água no solo conjunta para os anos de 1988,1990 e 1991

20 Rendimento de grãos em função da lâmina total de água (irrigação e precipitação) para os anos de 1988, 1990 e 1991

21 Curva de rendimento conjunta para os anos de 1988, 1990 e 1991.

22 Análise gráfica de resíduos para a altura de planta na colheita e número de vagens por planta do feijoeiro nos anos de 1988, 1990 e 1991.

23 Análise gráfica de resíduos para o número de grãos por vagem e peso de 100 grãos do feijoeiro nos anos de 1988, 1990 e 1991

24 Análise gráfica de resíduos para rendimento de grãos e eficiència de uso da água do feijoeiro nos anos de 1988, 1990 e 1991 


\section{LISTA DE TABELAS}

1 Características fisicas do solo da área experimental.................................. 17

2 Características químicas do solo da área experimental............................. 17

3 Médias mensais dos parâmetros meteorológicos de maio a setembro (período experimental) para os anos de 1988, 1990 e 1991, CPAC - EMBRAPA, Planaltina - DF

4 Duração média para os três anos das fases fenológicas da cultura do feijoeiro. 26

5 Esquema de análise de variância e teste $\mathrm{F}$ para tratamentos.......................... 30

6 Médias das tensões da água no solo do limite superior para início das irrigações, em $\mathrm{kPa}$, observadas durante o ciclo da cultura, e respectivos desvios padrões (entre parênteses).

7 Medias das lâminas de água aplicadas em cada irrigação com desvio padrão entre parenteses.

$8 \quad$ Resultados gerais do experimento ......................................................... 38

9 Análise da variância e teste $F$ para tratamentos (tensão da água no solo), para a variável altura de planta na colheita, nos anos de 1988, 1990 e 1991

10 Altura de plantas (cm) em função da tensão da água no solo nos anos de 1988, 1990 e 1991

11 Análise da variância e teste $\mathrm{F}$ para tratamentos (tensão da água no solo), para a variável número de vagem por planta, nos anos de 1988, 1990 e 1991.

12 Número de vagens por planta em função da tensão da água no solo nos anos de 1988,1990 e 1991 .

13 Análise da variância e teste $F$ para tratamentos (tensão) da água no solo), para a variável número de grãos por vagem, nos anos de 1988, 1990 e 1991

14 Número de grãos por vagem em função da tensão da água no solo nos anos de 1988,1990 e 1991 
15 Análise da variância e teste de $\mathrm{F}$ para tratamentos (tensão da água no solo), para a variável peso de 100 grãos (g), nos anos de 1988, 1990 e 1991 .

16 Peso de 100 grãos (g) em função da tensão da água no solo nos anos de 1988 , 1990 e 1991

17 Análise da variância e teste F para tratamentos (tensão da água no solo), para a variável rendimento, em kg.ha ${ }^{-1}$, nos anos de 1988, 1990 e 1991

18 Rendimentos de grãos $\left(\mathrm{kg} \cdot \mathrm{ha}^{-1}\right)$ em função da tensão da água no solo nos anos de 1988,1990 e 1991 .

19 Análise da variância e teste F para tratamentos (tensão da água no solo), para a variável eficiência de uso de água, nos anos de 1988, 1990 e 1991

20 Eficiência de uso da água $\left(\mathrm{kg} \cdot \mathrm{mm}^{-1}\right)$ em função da tensão da água no solo nos anos de 1988,1990 e 1991.

21 Valores de tensão da água no solo em $\mathrm{kPa}$ antes de serem efetuadas as irrigações, obtidos através de tensiômetros para os tratamentos T1, T2 e T3 e blocos de gesso T4, T5 e T6 e lâminas de água, para o ano de 1988 (a irrigação em 06/06/88 corresponde a 12 dias após a semeadura).

22 Valores de tensão da água no solo em $\mathrm{kPa}$ antes de serem efetuadas as irrigações, obtidos através de tensiômetros para os tratamentos T1, T2 e T3 e blocos de gesso T4, T5 e T6 e lâminas de água, para o ano de 1990 (a irrigação em 13/06/90 corresponde a 16 dias após a semeadura).

23 Valores de tensão da água no solo em $\mathrm{kPa}$ antes de serem efetuadas as irrigações, obtidos através de tensiômetros para os tratamentos T1, T2 e T3 e blocos de gesso T4, T5 e T6 e lâminas de água, para o ano de 1991 (a irrigação em 11/06/91 corresponde a 15 dias após a semeadura).

24 Diagramas de ramos e folhas para as variáveis estudadas 


\section{LISTA DE ABREVIATURAS E SÍMBOLOS}

$\theta$ - umidade a base de volume $\left(\mathrm{cm}^{3} \mathrm{H}_{2} \mathrm{O} \cdot \mathrm{cm}^{-3}\right.$ solo)

$\psi$ - potencial matricial

ALPL - altura de planta

Atm - atmosfera

CPAC - Centro de Pesquisa Agropecuária dos Cerrados

CUD - coeficiente de uniformidade de distribuição

CUC - coeficiente de uniformidade de Christiansen

DAS - dia após semeadura

EUA - eficiência de uso da água

LAM - lâmina de água

LVA - Latossolo Vermelho-Amarelo

LVE - Latossolo Vermelho-Escuro

NGV - número de grãos por vagem

NVPL - número de vagem por planta

P100G - massa de 100 grãos

REND - rendimento de grãos

$\mathrm{T}$ - tratamento 


\title{
ESTABELECIMENTO DO MOMENTO DE IRRIGAÇÃO COM BASE NA TENSÃo dA ÁGUA NO SOLO PARA A CULTURA DO FEIJOEIRO
}

\author{
Autor: SEBASTIÃO FRANCISCO FIGUERÊDO \\ Orientador: Prof. Dr.JOSÉ ANTONIO FRIZZONE
}

\section{RESUMO}

Esse trabalho foi desenvolvido no Centro de Pesquisa Agropecuária dos Cerrados, Brasília-D.F., durante três anos $(1988,1990$ e 1991), o qual teve como objetivo principal estudar os efeitos de diferentes níveis de tensão da água no solo na produtividade e componentes de produção, para estabelecer o momento de irrigação na cultura do feijoeiro. Os tratamentos consistiram dos seguintes níveis de tensão preestabelecidos de água no solo: $33 \mathrm{kPa}(\mathrm{T} 1) ; 50 \mathrm{kPa}(\mathrm{T} 2) ; 70 \mathrm{kPa}(\mathrm{T} 3) ; 100 \mathrm{kPa}(\mathrm{T} 4)$; $500 \mathrm{kPa}(\mathrm{T} 5)$ e $1000 \mathrm{kPa}(\mathrm{T} 6)$. Sendo as irrigações realizadas quando os valores de tensão da água no solo se encontravam em torno dessa tensão preestabelecida, simultâneamente em todas as repetições dentro de cada tratamento. Utilizaram-se tensiômetros para monitorar as tensões de $33 \mathrm{kPa}(\mathrm{T} 1) ; 50 \mathrm{kPa}(\mathrm{T} 2)$ e $70 \mathrm{kPa}$ (T3) e blocos de gesso para as demais tensões da água no solo, ambos instalados a $10 \mathrm{~cm}$ de profundidade. A quantidade de água aplicada em cada irrigação foi calculada para elevar a umidade do 
solo à capacidade de campo até a profundidade de $40 \mathrm{~cm}$. Os resultados mostraram que para os anos de 1988, 1990 e 1991 os tratamentos com as tensões observadas de água no solo $54 \mathrm{kPa}(\mathrm{T} 2), 37 \mathrm{kPa}(\mathrm{T} 1)$ e $39 \mathrm{kPa}(\mathrm{T} 1)$, apresentaram maiores rendimentos de grãos, na ordem de $2.973,3.022$ e $3.320 \mathrm{~kg} \cdot \mathrm{ha}^{-1}$, para as lâminas totais aplicadas de 571 , 528 e $602 \mathrm{~mm}$ respectivamente. O rendimento de grãos reduziu-se continuamente em função do aumento da tensão da água no solo no intervalo entre $37 \mathrm{kPa}$ a $967 \mathrm{kPa}$, seguindo um comportamento logarítmico. Comportamento igual foi encontrado para as variáveis altura de planta, número de vagens por planta e número de grãos por vagem. A irrigação realizada com a tensão de água no solo de $917 \mathrm{kPa}$, em relação à tensão de 36 $\mathrm{kPa}$, reduziu a produtividade em $27 \%$, porém houve uma economia de $48 \%$ no volume total de água utilizado. O rendimento de grãos em função das lâminas totais apresentou comportamento quadrático sendo que os maiores rendimentos foram obtidos quando irrigados com tensão da água no solo de $37 \mathrm{kPa}$. 


\title{
CRITICAL TENSION FOR ESTABLISHMENT OFTHE MOMENT FOR IRRIGATION OF DRYBEAN
}

\author{
Author: SEBASTIÃO FRANCISCO FIGUERÊDO \\ Adviser: Prof. Dr.JOSÉ ANTONIO FRIZZONE
}

\section{SUMMARY}

This work was conducted at the Centro de Pesquisa Agropecuária dos Cerrados, Brasilia, D.F., during three years $(1988,1990$ and 1991) with the objective of studing the effects of different soil water tension levels in an attempt to establish the adequate moment of irrigation for drybean. The treatments included the following levels of soil water tension: $33 \mathrm{kPa}(\mathrm{T} 1) ; 50 \mathrm{kPa}(\mathrm{T} 2) ; 70 \mathrm{kPa}(\mathrm{T} 3) ; 100 \mathrm{kPa}(\mathrm{T} 4) ; 500 \mathrm{kPa}(\mathrm{T} 5)$ and $1000 \mathrm{kPa}(\mathrm{T} 6)$. Tensiometers were used measure the tension for $\mathrm{T} 1, \mathrm{~T} 2$ e $\mathrm{T} 3$ and gypsum resistence blocks for the remaining treatments. The amount of water applied in each irrigation was calculated to replace soil moisture to the field capacity up to the depth of $40 \mathrm{~cm}$. The treatments $54 \mathrm{kPa}(\mathrm{T} 2), 37 \mathrm{kPa}(\mathrm{T} 1)$ and $39 \mathrm{kPa}(\mathrm{T} 1)$, measured at the depth of $10 \mathrm{~cm}$, resulted in the highest grain yields, respectively, 2973, 3022 and $3320 \mathrm{~kg} \cdot \mathrm{ha}^{-1}$. The irrigation depths were 571, 528 and 602mm, respectively, for 1988, 1990 and 1991. The grain yeld as a funtion of irrigation depht showed a quadratic behavior and the highest value was obtained when irrigation was applied at tension $37 \mathrm{kPa}$. Irrigation at $917 \mathrm{kPa}$, comparing to $36 \mathrm{kPa}$, reduced yeld by $27 \%$, on the other hand there was an economy of 
$48 \%$ in the total water used. Productivity was continually reduce as tension was increased from 37 to 967 , following logarithmic behavior. The same behavior was found for plant height, number of seeds per plant and the number of seed per pod. 


\section{INTRODUÇÃO}

Em função do regime de chuvas característico da maior parte da região dos Cerrados, com o período seco que se estende de maio a setembro e o período chuvoso de outubro a abril, dois tipos de irrigação podem ser praticados: a irrigação total durante o período seco e a irrigação complementar por ocasião dos veranicos, durante a época chuvosa. A irrigação total, além de permitir a produção na época seca, possibilita a utilização de recursos como máquinas e mão-de-obra na época em que normalmente as atividades agrícolas na região estão paralisadas. Por outro lado, a irrigação complementar visa basicamente suprir de água as culturas normalmente plantadas na época chuvosa e sujeitas aos efeitos dos veranicos, impedindo assim quebras significativas na produção.

A irrigação, como qualquer prática agrícola, por si só não garante boas colheitas. Quando, porém, acompanhada de práticas recomendáveis como escolha de variedades produtivas, uso de sementes selecionadas e adubação em quantidade e épocas apropriadas elevam os índices de produtividade além de superar aqueles normalmente alcançados, principalmente na entressafra quando os produtos alcançam melhores preços.

Em solos sob Cerrados o manejo da irrigação necessita de adaptações em face das características peculiares de clima e solo. Essas adaptações, constituem metas da pesquisa e objetivam a recomendação de práticas de manejo específico para cada modalidade de irrigação, visando sempre a economia de água, um recurso escasso nessa região.

Existem várias metodologias e critérios que podem ser utilizados para se estabelecer a programação das irrigações, que vão desde simples turno de rega a complexos esquemas de integração do sistema solo-água-planta-atmosfera (Haise \& 
Hagan, 1967; Doorenbos \& Pruitt, 1975). Entretanto, muitas destas metodologias ainda não são acessiveis para uso prático pelos agricultores irrigantes. Reconhece-se que o agricultor só irá adotar uma recomendação de irrigação caso ela seja suficientemente simples e precisa, de baixo custo, resulte em economia de energia e possibilite, no campo, a determinação do momento mais adequado para as irrigações.

Medidas de tensão de água no solo têm sido consideradas como alternativas adequadas para avaliação indireta da deficiência hídrica de uma cultura (Hermann et al., 1990) e portanto, passíveis de utilização em esquemas de manejo da irrigação. Neste caso, o tensiômetro tem sido apontado como instrumento suficientemente preciso e simples para estabelecer o momento de irrigação (Haise \& Hagan, 1967) e indiretamente determinar quantidade de água necessária para reposição ao solo por ocasião da irrigação (Richards \& Marsh, 1961).

Estudo sobre efeito das lâminas de água e da quantidade de nitrogênio aplicados na cultura do feijoeiro relata sobre produtividade de grãos de $2.400 \mathrm{~kg} \cdot \mathrm{ha}^{-1}$, com $500 \mathrm{~mm}$ de água e $120 \mathrm{~kg} \cdot$ ha $^{-1}$ de nitrogênio (Frizzone et al., 1987).

Os latossolos dos Cerrados, em geral, apresentam características de disponibilidade de águas típicas de um solo arenoso, girando em torno de $1 \mathrm{~mm}$ de água por cada $\mathrm{cm}$ de solo (Wolf, 1975), sendo que $65 \%$ do total da água disponível se encontra retida a tensões inferiores a 1 atm (Azevedo et al., 1983) e, portanto, dentro da faixa de leitura coberta pelo tensiômetro. Assim sendo, considera-se viável a utilização deste instrumento para determinar o momento das irrigações pela medida de tensão de água nesses tipos de solo.

Para tensões acima da faixa de uso da tensiometria, pode-se utilizar os blocos de resistência elétrica ou blocos de gesso que têm a função de medir a resistência à passagem da corrente elétrica entre dois eletrodos enterrados no solo, que por si irão permitir verificar a umidade ou tensão de água do solo. Os blocos de gesso são considerados satisfatórios para o monitoramento da irrigação. 
O presente trabalho teve como objetivo estabelecer o nível de tensão de água no solo com a finalidade de determinar o momento de irrigação, possibilitando indicar técnicas de manejo que resultem na maximização da produtividade. 


\section{REVISÃO DE LITERATURA}

\subsection{O cultivo do feijoeiro (Phaseolus vulgaris L.) no Brasil.}

No Brasil o cultivo do feijoeiro é praticado em todo o território nacional nos mais diversificados tipos de solo, sistemas de produção e climas. As recomendações sobre sistemas de plantios compreendem os cultivos solteiros e consorciados, mas esta última condição é aconselhável somente para aqueles que cultivam pequenas áreas.

O cultivo do feijoeiro, apresenta-se, como cultura de baixo risco de produção e para o mercado consumidor não se mostra saturado sendo que a maioria dos produtores podem contar com grande potencial para obter altas produtividades ao mesmo tempo que há possibilidade de redução dos custos. Atualmente os investimentos em tecnologia são viáveis especialmente em áreas onde as chuvas nas épocas de colheita promovam riscos mínimos de perdas (Agrianual, 1996).

Os gêneros mais usados são o Phaseolus e Vigna, comumente encontrados nos mais variados tamanhos, com diferentes cores. De acordo com Azevedo \& Caixeta (1986) e Stone \& Moreira (1986), a cultura do feijoeiro vem se tornando uma das alternativas mais rentáveis em sistemas irrigados na região dos Cerrados e informações sobre manejo de água utilizando tensiômetros, ainda não são suficientes para estabelecer uma base de conhecimentos precisa para a utilização da tensiometria, visando altas produtividades com as variedades lançadas mais recentemente. Com o passar dos anos as afirmações desses autores ainda continuam procedentes, devido ao fato de que tecnologias sobre manejo de irrigação para essa cultura ainda não são dominadas plenamente pelos produtores, exigindo-se portanto dar continuidade aos estudos na área de tensão de água do solo para obter elevadas produtividades. 
A utilização inadequada de tecnologias e uso de processos rudimentares são apontados como causas dos baixos rendimentos da cultura do feijoeiro no Brasil. Apesar da pesquisa já dispor de resultados com capacidade para triplicar a produtividade atual, são insignificantes os avanços obtidos, de modo que, na maioria dos casos, a produção nacional ainda é conduzida predominantemente por pequenos produtores, que por questões socio-econômicas, não se adequam à adoção de novas tecnologias.

Conforme estudos realizados, os custos de implantação da cultura do feijoeiro no período seco são bastante altos, portanto o uso da irrigação torna-se obrigatório. Teixeira et al. (1978) verificaram que a produtividade mínima necessária para que a cultura do feijoeiro seja economicamente viável, sob regime de irrigação por aspersão, é de 1500 $\mathrm{kg} \cdot \mathrm{ha}^{-1}$. Almeida et al. (1990) verificaram que é necessário uma produtividade mínima de $1033 \mathrm{~kg} \cdot \mathrm{ha}^{-1}$, para viabilizar economicamente a implantação da cultura sob irrigação. Entretanto, podem ocorrer variações devido à instabilidade econômica em curto espaço de tempo, tanto nos custos, como nos preços obtidos pelo produto, assim os limites acima poderão ser também muito variáveis.

Para a região dos Cerrados recomendações de manejo de irrigação em função da tensão da água no solo podem ser extrapolados para outros solos de condições semelhantes, pois refletem as variações edafoclimáticas no tempo e no espaço, bem como as diferenciações do consumo de água nas diversas fases de crescimento da planta (Guerra et al., 1987).

No manejo de água em sistemas irrigados um dos aspectos fundamentais é a definição do momento das irrigações, pois a aplicação de água no momento certo é um dos fatores mais importantes para o sucesso da agricultura irrigada. Por outro lado, uma programação racional das irrigações, ao longo do ciclo das culturas, não pode ser definida com êxito, sem o conhecimento preciso do método utilizado para o manejo das irrigações (Azevedo \& Silva, 1983).

Guerra et al. (1994) citam vários métodos ou critérios para estabelecer esquemas de irrigação como: a) relacionar a evapotranspiração da cultura com a evaporação do 
tanque Classe A (Pruitt \& Lourence, 1968; Choudhury \& Kumar, 1980); b) relacionar a necessidade de reposição da água no solo com a água disponível no perfil do solo (Mishra et al., 1969; Singh et al., (1980); c) usar um esquema de irrigação fixo, baseado no estádio de desenvolvimento da cultura (Bhan, 1977), associando a necessidade de água das culturas, com a temperatura do dossel (Pinter Junior et al., 1990); e d) relacionar a necessidade de irrigação à tensão de água no solo (Phene et al., 1989; Marouelli et al., 1991).

Folegatti (1987) realizou trabalho com a cultura do feijoeiro fazendo-se o monitoramento com um microprocessador portátil "Scheduler", por meio de sensores, registrou medidas instantâneas da temperatura ambiental, radiação solar e umidade relativa do ar, os quais indicaram o índice de estresse hídrico da cultura, informando portanto, o momento da irrigação.

A utilização de tecnologias adequadas tem demonstrado que é possível obter altas produções, portanto, é necessário que se coloque em prática recomendações como fertilidade do solo, época do plantio, boa semente, preparo do solo, irrigação na quantidade e na hora certa, controle de doenças e pragas, dentre outros fatores, os quais são indicadores fundamentais para o sucesso na produção agrícola.

Segundo registros do Agrianual (1996) nos últimos anos no Brasil ocorreram aumentos na produtividade do feijão, citando a produtividade de $1000 \mathrm{~kg} \cdot \mathrm{ha}^{-1}$ como baixa, de $1600 \mathrm{~kg} \cdot \mathrm{ha}^{-1}$ como média, e de $2300 \mathrm{~kg} \cdot \mathrm{ha}^{-1}$ como alta produtividade.

Um dos pontos principais a serem considerados para o sucesso a longo prazo na agricultura é a rotação de culturas. Esse aspecto é enfatizado por Curl (1963), ao mencionar que os cultivos de leguminosas, principalmente o feijão, têm favorecido o aparecimento de doenças do solo, como rizoctoniose, esclerotínea e fusariose, e recomenda a rotação de culturas como um dos fatores preponderantes para o sucesso neste tipo de exploração. Este autor encontrou que a sucessão gramínea e leguminosa mostrou uma drástica redução no poder de inóculo de doenças existentes no solo que afetam o sistema radicular, trazendo sérios problemas no cultivo em áreas irrigadas. 


\subsection{Irrigação e produtividade do feijoeiro}

Estudo realizado por Frizzone (1986), com o objetivo de avaliar o efeito do nitrogênio e da água no rendimento do feijoeiro, indicou que o máximo rendimento de grãos foi de $2261,8 \mathrm{~kg}$.ha ${ }^{-1}$ obtido com $570,4 \mathrm{~mm}$ de água e $117,4 \mathrm{~kg} \mathrm{ha}^{-1}$ de nitrogênio. A análise econômica dos dados revelou que a máxima receita líquida é obtida quando utiliza-se uma lâmina de $570,4 \mathrm{~mm}$ e $90 \mathrm{~kg} \cdot \mathrm{ha}^{-1}$ de nitrogênio. Neste trabalho o manejo da irrigação foi feito com base nos dados de evaporação do tanque classe $\mathrm{A}$, de acordo com as recomendações sugeridas pela FAO (Doorenbos \& Kassan, 1979).

Nas condições de Ilha Solteira, SP, Queiroz et al. (1996), utilizaram as funções de resposta da cultura do feijoeiro obtidas por Frizzone (1986), e concluíram que dependendo da situação, mesmo a utilização da lâmina ótima pode não justificar o investimento com a irrigação naquele nível de manejo.

Forsythe \& Legarda (1978) demonstraram que a produção de grãos de feijão, de matéria seca da parte aérea e número de vagens por planta foram máximas quando irrigou-se a 0,8 bar a $5 \mathrm{~cm}$ de profundidade ou 0,6 bar a $15 \mathrm{~cm}$ de profundidade do solo, usando a cultivar " $27-\mathrm{R}$ ".

O déficit hídrico no período compreendido entre a floração e formação de grãos provoca as maiores quedas no rendimento (Garrido et. al., 1979). Entretanto, os mesmos autores concordam que a deficiência hídrica em qualquer fase do ciclo da cultura provoca redução na produção. O déficit hídrico durante o período vegetativo reduz o seu crescimento, havendo a possibilidade de recuperação do seu vigor com reinício da irrigação.

Trabalho realizado em La Platina, Chile, por Bascur \& Fritsch (1971) no qual estudou-se o efeito do déficit hídrico nas fases fenológicas da cultura em função de diferentes níveis de tensão da água no solo, por meio de tensiômetros instalados a $20 \mathrm{~cm}$ de profundidade, observaram que na tensão de 0,4 atm obteve-se o maior peso de grãos. Stone et al. (1988) verificaram em um latossolo vermelho escuro com perfil homogêneo quanto a textura e à capacidade de retenção de água, que não houve diferenças com 
relação a produtividade do feijoeiro, quando se controlou a tensão da água no solo a 15 e $30 \mathrm{~cm}$ de profundidade. Trabalho realizado em Esperanza, na Argentina, por Favaro \& Pilatti (1987), mostrou que a temperatura alta favorece o crescimento de vagens e consequentemente das sementes e que o estresse hídrico afeta o desenvolvimento e o número de sementes por vagens. Couto (1979) verificou que o estresse hídrico reduziu o peso das sementes e, em seguida, o número de vagens por planta, de forma que estes foram os fatores mais afetados em se tratando dos componentes de produção, ocorrendo ao contrário para o número de grãos por vagem o qual foi o menos afetado. Vieira et al. (1989) observaram que o maior esgotamento hídrico do solo ocorreu no estágio de formação de vagens. Para Robins et al. (1967) os períodos de déficit hídrico prolongado durante a floração provocam redução tanto no número de vagens quanto no número de sementes por vagens, por outro lado essas perdas são compensadas em parte, pelo aumento do peso de sementes. Em condições de déficit hídrico prolongado e severo, ocorrido na fase de maturação, o rendimento fica comprometido em função da redução do peso das sementes. Pozzebon (1995) estudando o comportamento do feijoeiro ao déficit hídrico no sul do Brasil, verificou que o número de vagens e o número de sementes por vagens foram afetados. Diversos estudos sobre o déficit hídrico na fase de floração confirmam a redução da produtividade (Hostalácio \& Válio, 1988; Magalhães et al., 1979). Durante o período crítico, a produtividade está intimamente relacionado com o número de dias de deficiência da água no solo. Magalhães \& Millar (1978) relatam que o rendimento foi reduzido em $20 \%$ quando a cultura permaneceu sem irrigação por 14 dias no período da floração e quando o período de deficiencia foi de 17 a 20 dias a redução variou de 30 a $52 \%$. A deficiência hídrica ocorrida durante a fase de desenvolvimento vegetativo é prejudicial ao feijoeiro, que também contribui para a redução dos componentes da produção como o peso das sementes e o número de vagens por plantas, conforme concluem Miranda \& Belmar (1977). Parjol (1976) comenta que, quando o estresse coincide com a fase de desenvolvimento vegetativo, o tamanho das plantas é reduzido mas o prejuízo seria maior se o mesmo ocorresse durante a floração e formação 
de vagens. Em Barreiras-BA, Oliveira e Silva (1990) observaram que na fase final da floração e início do enchimento de vagens, entre 52 e 58 dias do ciclo do feijoeiro, o consumo de água foi maior, sendo da ordem de $5,3 \mathrm{~mm} \cdot \mathrm{dia}^{-1}$. Com base em relato de vários autores sobre a tensão que o solo deve atingir para que sejam feitas as irrigações sem comprometer a produção, Bascur \& Fritsch (1975) concluíram ser 0,45 bar, com o tensiômetro instalado a profundidade de $20 \mathrm{~cm}$. Mack \& Varseveld (1982), recomendam a profundidade de instalação de $30 \mathrm{~cm}$, com leituras de 0,60 bar. Costa (1986) comparou dois regimes hídricos e três doses de nitrogênio e concluíram que, com o aumento da dose de nitrogênio, o efeito do estresse hídrico foi minimizado e que a fotossintese líquida aumentou quando houve o acréscimo da dose de nitrogênio.

Arruda (1987) em experimento conduzido em Campinas-SP, instalou tensiômetros a $15 \mathrm{~cm}$ de profundidade, considerando que maior concentração de raízes do feijoeiro encontra-se na camada entre 20 e $30 \mathrm{~cm}$ do perfil do solo, obteve maior produção com $300 \mathrm{~mm}$ de água aplicada. Silveira (1990) conduzindo experimento em Goiânia com o feijão Carioca, observou consumo de água de $350 \mathrm{~mm}$ durante todo o ciclo da cultura.

Azevedo \& Caixeta (1986) revendo os dados de literatura observaram que a produção de feijão irrigado é alta, com uma média de $1800 \mathrm{~kg} \cdot \mathrm{ha}^{-1} \mathrm{em}$ contraposição ao feijão não irrigado, cultivado no período chuvoso, cuja produção média é de 500 a 850 $\mathrm{kg} \cdot \mathrm{ha}^{-1}$, sendo a mesma considerada baixa.

\subsection{Consumo de água pela cultura do feijoeiro}

Em trabalho apresentado por Cordeiro (1977) sobre caracterização de Latossolo argiloso médio de cerrado, foi observado que a água disponível entre 0,33 e 15 bar é inferior a $1 \mathrm{~mm} . \mathrm{cm}^{-1}$ de solo e que à tensão 1 bar estes solos retém cerca da metade da capacidade máxima de água disponível. O mesmo autor mostrou que o Latossolo Vermelho Escuro argiloso possui mais água disponivel que o Latossolo Vermelho Amarelo Médio. No entanto, Wolf (1975) estudando o Latossolo Vermelho Escuro 
Argiloso (45\% de argila) e Latossolo Vermelho Amarelo (30\% de argila) mostrou que disponibilidade de água, variando de 34 a $44 \mathrm{~mm}$ por $30 \mathrm{~cm}$ de solo, era $30 \%$ maior no Latossolo Vermelho Amarelo, em comparação ao Latossolo Vermelho Escuro, por sua estrutura ser altamente estável devido o grande número de agregados.

Hegde \& Srinivas (1989), no Instituto de Pesquisa de Horticultura em Bangalore - India, trabalharam com diferentes níveis de tensão da água no solo, e observaram que, para a tensão de água no solo de $-45 \mathrm{kPa}$, medida a $15 \mathrm{~cm}$ de profundidade, a eficiência de uso de água foi maior.

Trabalho conduzido por Saad \& Libardi (1994) com a cultura do feijoeiro irrigado por pivô central, apresenta valores de eficiência de uso de água com variação no intervalo de $0,65 \mathrm{~kg} \cdot \mathrm{m}^{-3}$ e $0,80 \mathrm{~kg} \cdot \mathrm{m}^{-3}$ para condições de excesso de água e lâmina média aplicada, respectivamente. Concluíram, que nas áreas onde houve déficit, as plantas utilizaram a água com mais eficiência do que nas áreas onde aplicou-se água em excesso.

Stone \& Moreira (1995) estudando a cultivar Aporé com relação ao efeito do solo e do manejo no consumo de água, observaram que o sistema de plantio direto com cobertura morta que apresentou maior eficiência no uso da água foi com $382 \mathrm{~mm}$ de lâmina.

\subsection{Manejo da irrigação}

O consumo de água pelo feijoeiro geralmente não ultrapassa $3,0 \mathrm{~mm} \cdot$ dia $^{-1}$, quando na fase inicial do ciclo da cultura. Porém na fase de crescimento acelerado e reprodutiva, atinge 5,0 mm/dia (Fancelli, 1990). Para condições de umidade baixa e alta temperatura, Caixeta (1978) relata que o consumo de água pode ultrapassar os 5,0 $\mathrm{mm}$ diários. Com relação à temperatura, Fancelli (1990) comenta que regiões com temperatura situada entre $17^{\circ} \mathrm{C}$ e $29^{\circ} \mathrm{C}$, são considerados aptas para o seu cultivo, e que a temperatura média ideal é de $21^{\circ} \mathrm{C}$.

Luchiari Júnior (1978) estimou a evapotranspiração real (Eta) média da cultura do feijão na época seca em $3,06 \mathrm{~mm} \mathrm{dia}^{-1}$, da germinação à fase de maturação. Saad e 
Libardi (1994) observaram em Guaira-SP, que a evapotranspiração média em 80 dias do ciclo da cultura foi de $3,38 \mathrm{~mm} \cdot \mathrm{dia}^{-1}$. Frizzone (1986) e Costa (1986) citam vários trabalhos nos quais os autores estimaram para a cultura do feijoeiro de inverno, um intervalo de consumo de água de 3,0 a $5,3 \mathrm{~mm}_{\text {dia }}{ }^{-1}$ no periodo de maior demanda evapotranspirativa, para diferentes regiões do Cerrado brasileiro. Reichardt et al. (1974), em Piracicaba, encontraram valor mais elevado para a Eta, ou seja de $5,3 \mathrm{~mm}^{-d_{a}{ }^{-1}}$, para a fase de florescimento, e na fase de formação de grãos foi de $4,6 \mathrm{~mm} \cdot \mathrm{dia}^{-1}$. Ressaltam também que o déficit hídrico reduziu todos os componentes de produção do feijoeiro.

Segundo Barros e Hanks (1993) aumentos na produtividade dão indícios de estar estreitamente relacionados ao efeito da cobertura morta, por esta reduzir a evaporação e aumentar a transpiração. Os autores encontraram que a cobertura morta aumentou a eficiência do uso da água e a produtividade do feijoeiro em todos os níveis de irrigação estudados.

Steinmetz (1984) conduzindo trabalho em Goiânia, com a variedade CNF 10, encontrou um consumo médio de $3,4 \mathrm{~mm} \cdot \mathrm{dia}^{-1}$, da emergência à floração, observando que durante a floração, este foi de $6,0 \mathrm{~mm}^{- \text {dia }^{-1}}$ e para o período de desenvolvimento de vagens até a maturação foi de $4,7 \mathrm{~mm} \cdot$ dia $^{-1}$. Costa et al. (1991) e Vieira et al. (1987) em experimentos na área da ESALQ/USP, observaram que o maior esgotamento hídrico do solo ocorreu no estádio de formação de vagens.

Oliveira \& Silva (1990), observaram para a cultivar IPA 74-19, que a máxima evapotranspiração da cultura ocorre quando o índice de área foliar (IAF) é máximo e o efeito da área foliar na fotossintese atua de maneira ativa quanto a demanda de água pelas plantas. Dourado Neto et al. (1987), referindo-se a ordem de grandeza da evapotranspiração, relatam que esta depende da cultura e dos atributos climáticos, em caracter especial, a umidade relativa do ar e temperatura, os quais são os parâmetros principais para definir-se o potencial total de água na atmosfera, juntamente com os fatores velocidade e constância do vento. 
Para o Distrito Federal e os Estados de Goiás, Minas Gerais, Espírito Santo, São Paulo e Rio de Janeiro, a Empresa Brasileira de Pesquisa Agropecuária (EMBRAPA, 1989) apresenta o consumo de água para a cultura do feijoeiro, no intervalo de 300 a 500 $\mathrm{mm}$ durante o ciclo vegetativo, de modo que nas fases de floração e enchimento de vagens, concentra o maior consumo diário, podendo atingir até $6 \mathrm{~mm} \cdot \mathrm{dia}^{-1}$.

\subsection{Instrumentos utilizados na medição da tensão da água no solo}

Existem vários critérios para indicar o comportamento da água no solo, porém, a medida do potencial mátrico através das leituras de tensiômetros, tem sido um dos mais utilizados, em função da facilidade de aquisição dos mesmos. Haise \& Hagan (1967) verificaram que dentre os critérios para indicar as condições em que encontra-se a água no solo, o método da tensão é bastante consistente para o controle das irrigações. Bernardo (1989) comenta que os tensiômetros são recomendados para utilização no limite de precisão, quais sejam, medidas menores que $75 \mathrm{kPa}$.

De acordo com Saad \& Libardi (1992), a leitura do tensiômetro de $15 \mathrm{~cm}$ de profundidade representa a tensão média de um perfil de solo na camada de $0-30 \mathrm{~cm}$, na qual encontra-se a maior concentração do sistema radicular. Para o tensiômetro instalado nessa profundidade denominou-se tensiômetro de decisão, devido ser esse o indicador do momento de irrigação.

Azevedo et al. (1986) apresentaram metodologia para ajustes de leituras dos tensiômetros, alertando que antes de serem levados ao campo, os mesmos sejam cuidadosamente testados em laboratório, evitando-se assim possíveis vazamentos. Azevedo \& Caixeta (1986) citando Daker (1973), mencionam que o uso do tensiômetro exige certa habilidade do operador, tanto no preparo do aparelho como em sua instalação no campo, de modo a promover um intimo contacto entre o solo e a cápsula. Qualquer entrada de ar prejudica seu funcionamento. No uso do tensiômetro para o cálculo da lâmina a ser aplicado, deve-se ter para cada tipo de solo a curva característica, que converta a tensão lida no aparelho em percentagem de água existente no solo. 
Os blocos de resistência elétrica para estimativa do conteúdo de água no solo são constituídos de dois eletrodos, os quais são envolvidos por uma massa absorvente de gesso, nylon, fibra de vidro ou outros materiais. Bouyoucos e Mick (1940) realizaram pesquisas sobre os blocos de gesso, considerando-os como instrumentos convenientes para o estabelecimento do momento de irrigação com base na resistência elétrica. Segundo Tanner (1949) os blocos de gesso prestam-se satisfatoriamente para a obtenção de dados úteis no controle da umidade do solo em condições de campo, ainda que não apresentem grau de precisão equivalente aos obtidos em laboratórios.

A quantidade de água contida em um bloco enterrado no solo varia com o seu potencial matricial. Assim, é possivel a determinação indireta do potencial matricial a partir de propriedades elétricas ou de temperatura do mesmo, que variam com o seu conteúdo de água. $\mathrm{O}$ efeito da histerese entre o conteúdo de água e o potencial matricial do bloco podem ocasionar diferentes curvas de calibração para o mesmo (Hillel, 1980).

Os blocos de gesso utilizados no monitoramento de umidade devem ser calibrados antes de serem instalados no campo pois, em cada tipo de solo, eles apresentam diferentes comportamentos. Devem ser cobertos com o mesmo tipo de solo onde será instalado em campo e fazer o acompanhamento através de leituras da resistência em Ohms $(\Omega)$, até que atinjam peso constante ou alta resistência (maior que $100 \mathrm{k} \Omega$ ). A determinação do conteúdo de água do solo, via leituras de resistência elétrica, é viável, desde que sejam feitas curvas de calibração relacionando o conteúdo de umidade com medidas de resistência elétrica (Gardner, 1965). A panela de pressão de uso em laboratório, pode ser utilizada para esta calibração com facilidade (Haise e Kelley, 1946). Observações sobre calibração de blocos de gesso na literatura foram feitas também em trabalhos realizados por (Cannell \& Asbell, 1964; Silva, 1991; Spaans \& Bake, 1992).

Contudo, existem outros fatores que interferem nas leituras dos blocos de resistência elétrica, influenciando de modo negativo, destacando-se as características fisicas do gesso utilizado na sua fabricação e a dispersão de corrente elétrica no solo, não 
permitindo a passagem da mesma através dos eletrodos do bloco e também a temperatura e a salinidade do solo (Gornat \& Silva, 1990). 


\section{MATERIAL E MÉTODOS}

\subsection{Descrição da área experimental}

O trabalho foi conduzido durante três anos (1988, 1990 e 1991) no campo experimental do Centro de Pesquisa Agropecuária do Cerrados (CPAC), da EMBRAPA, situado em Planaltina, Brasília-DF, cujas coordenadas geográficas são, latitude $15^{\circ} 35^{\prime}$ $30^{\prime \prime} \mathrm{S}$, longitude $47^{\circ} 42^{\prime} 30^{\prime \prime} \mathrm{W}$ e altitude $1.014 \mathrm{~m}$.

\subsection{Delineamento experimental e tratamentos}

O delineamento experimental utilizado foi o de blocos ao acaso, com quatro repetições. Cada repetição foi composta de seis tratamentos, com parcelas nas dimensões de 3,5 $\mathrm{m} \times 6,0 \mathrm{~m}$, onde foram testados seis níveis de tensão da água no solo, previamente estabelecidos em $33 \mathrm{kPa}$ (T1), $50 \mathrm{kPa}$ (T1) e $70 \mathrm{kPa}$ (T3), $100 \mathrm{kPa}$ (T4), $500 \mathrm{kPa}$ (T5) e $1000 \mathrm{kPa}$ (T6). As fileiras de plantas foram dispostas no sentido do maior comprimento da parcela. Na Figura 1 apresenta-se o esquema experimental para os três anos estudados. Os números dentro dos retângulos indicam os tratamentos, representados pelas tensões de água no solo em $\mathrm{kPa}$ pré-estabelecidas, para o controle das irrigações. Nos três anos o experimento foi repetido na mesma área, porém com sorteio das parcelas em cada ano.

\subsection{Solo e adubação}

O solo da área experimental foi classificado como um Latossolo VermelhoEscuro, fase argilosa, cujas características fisicas e químicas estão apresentadas nas Tabelas 1 e 2 respectivamente. Na Figura 2 é apresentada a curva de retenção da água no solo. 
ANO: 1988

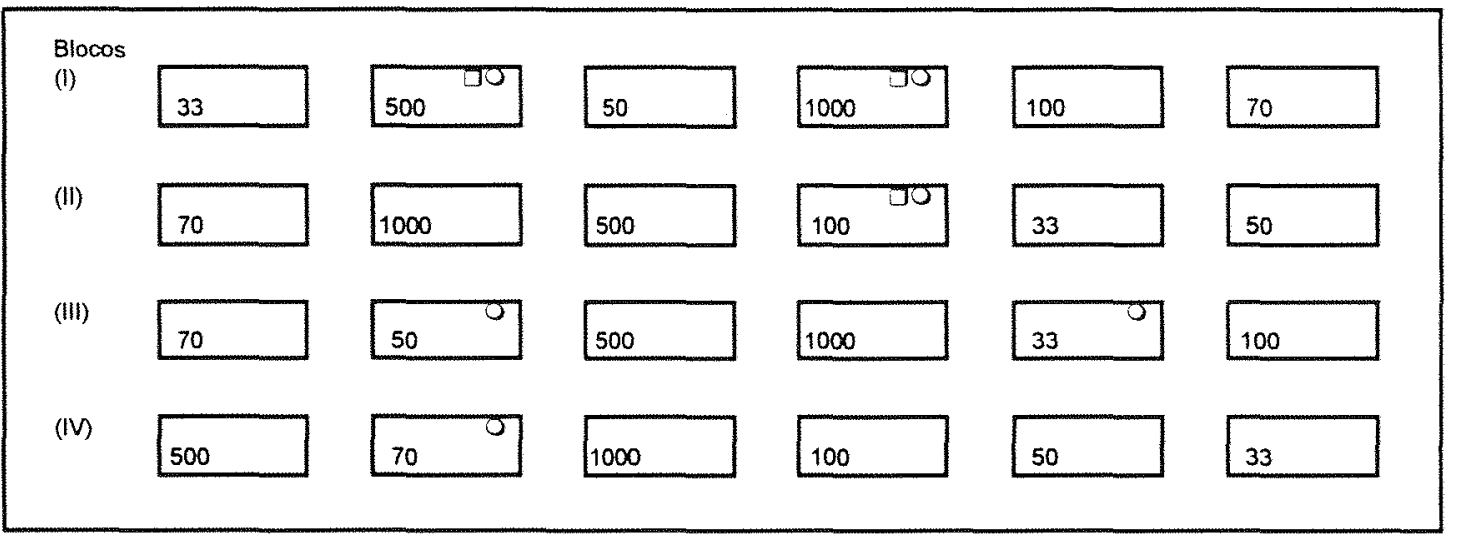

ANO: 1990

Blocos

(I)
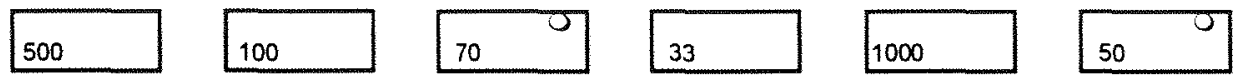

(II)
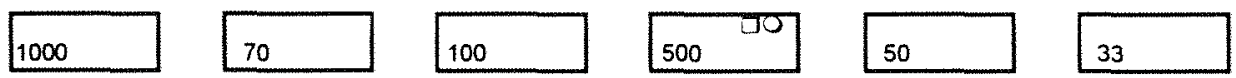

(III)
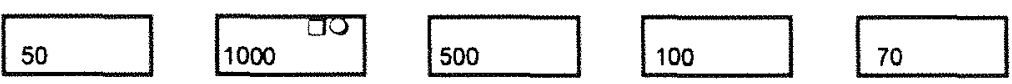

33

(IV)
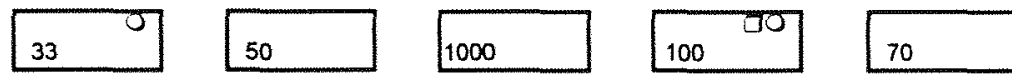

500

ANO: 1991

Blocos

(I)
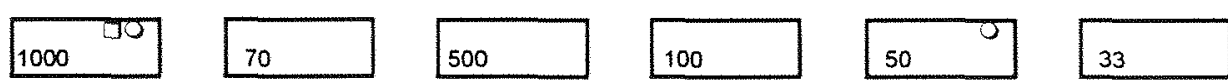

(II)
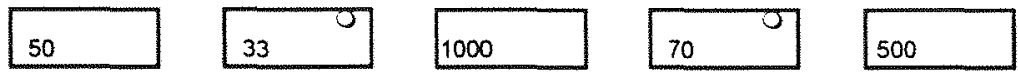

100

(III)
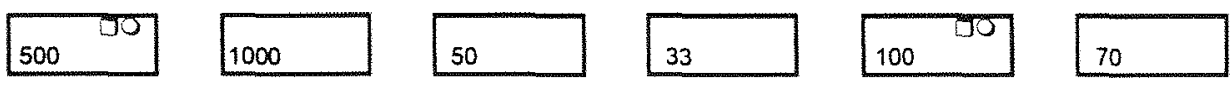

(IV)
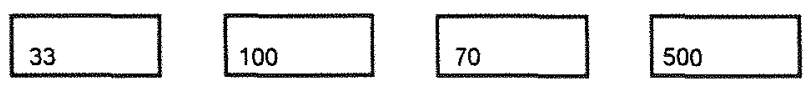

1000

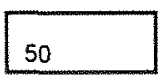

ÁREA TOTAL: $30 \times 60=1800 \mathrm{~m}^{2}$

PARCELA: $3,5 \times 6,0=21 \mathrm{~m}^{2}$

ESPAÇAMENTO ENTRE BLOCOS: $3.0 \mathrm{~m}$

ESPAÇAMENTO ENTRE TRATAMENTOS: $3,0 \mathrm{~m}$

๑o Bateria de tensiômetros e blocos de gesso

Figura 1 - Representação esquemática do experimento. 
Tabela 1 - Caracteristicas fisicas do solo da área experimental*.

\begin{tabular}{cccccc}
\hline $\begin{array}{c}\text { Profundidade } \\
\text { do solo }(\mathrm{cm})\end{array}$ & Argila & Silte & \multicolumn{2}{c}{ Areia } & \begin{tabular}{c} 
Densidade \\
\cline { 4 - 5 } global $\left(\mathrm{g} . \mathrm{cm}^{3}\right)$
\end{tabular} \\
\hline $0-15$ & 51 & 8 & Fina & Grossa & 1,07 \\
$15-30$ & 49 & 9 & 29 & 14 & 1,30 \\
$30-45$ & 50 & 9 & 30 & 11 & 1,11 \\
\hline
\end{tabular}

Tabela 2 - Características químicas do solo da área experimental*.

\begin{tabular}{|c|c|c|c|c|c|c|c|}
\hline \multirow[t]{2}{*}{ Ano } & \multirow{2}{*}{$\begin{array}{l}\text { Prof. do } \\
\text { Solo }(\mathrm{cm})\end{array}$} & \multirow{2}{*}{$\begin{array}{c}\mathrm{pH} \\
\left(\mathrm{H}_{2} \mathrm{O}\right)\end{array}$} & $\mathrm{Al}$ & $\mathrm{Ca}+\mathrm{Mg}$ & $\mathrm{P}$ & $\mathrm{K}$ & \multirow{2}{*}{$\begin{array}{c}\text { Mat. Org. } \\
(\%)\end{array}$} \\
\hline & & & \multicolumn{2}{|c|}{$\left(\mathrm{meq} 100 \mathrm{ml}^{-1}\right)$} & \multicolumn{2}{|c|}{$(\mathrm{ppm})$} & \\
\hline \multirow[t]{2}{*}{1988} & $0-15$ & 5,5 & 0 & 3,98 & 18,4 & 0,23 & 2,71 \\
\hline & $15-30$ & 5,7 & 0 & 3,60 & 3,5 & 0,15 & 2,07 \\
\hline \multirow[t]{2}{*}{1990} & $0-15$ & 6,5 & 0,02 & 5,49 & 12,0 & 63 & 2,66 \\
\hline & $15-30$ & 6,3 & 0 & 3,41 & 5,4 & 36 & 2,56 \\
\hline \multirow[t]{2}{*}{1991} & $0-15$ & 6,4 & 0,02 & 6,18 & 40,3 & 49,0 & 2,98 \\
\hline & $15-30$ & 6,2 & 0,02 & 4,73 & 10,3 & 103,0 & 2,42 \\
\hline
\end{tabular}

*Análises feitas nos laboratórios de Físico-hídrica e Fertilidade do Solo do CPAC-EMBRAPA, Planaltina, Brasília-DF.

A área, que em anos anteriores foi utilizada para experimentação com trigo, foi adubada em função da análise química, considerando-se que a fertilidade do solo não seria fator limitante ao desenvolvimento cultura. Aplicou-se os fertilizantes químicos, macro e micronutrientes segundo recomendações de Sousa et al. (1986) respectivamente, nas quantidades equivalentes a $130 \mathrm{~kg} \cdot \mathrm{ha}^{-1}$ de $\mathrm{P}_{2} \mathrm{O}_{5}$ na forma de termofosfato Yoorin, $108 \mathrm{~kg} \cdot \mathrm{ha}^{-1}$ de $\mathrm{K}_{2} \mathrm{O}$ sob a forma de cloreto de potássio, $97 \mathrm{~kg} \cdot \mathrm{ha}^{-1}$ de $\mathrm{Mg}$ na forma de magnésio e $40 \mathrm{~kg} \cdot \mathrm{ha}^{-1}$ de FTE BR-12. O nitrogênio foi suprido integralmente, inoculando-se as sementes, por ocasião do plantio, conforme recomendações de Peres et al. (1989). No período chuvoso de cada ano, antes da instalação do experimento, em toda a área experimental foi semeado milho para verificação da uniformidade da fertilidade sendo incorporados os restos culturais após a colheita. 


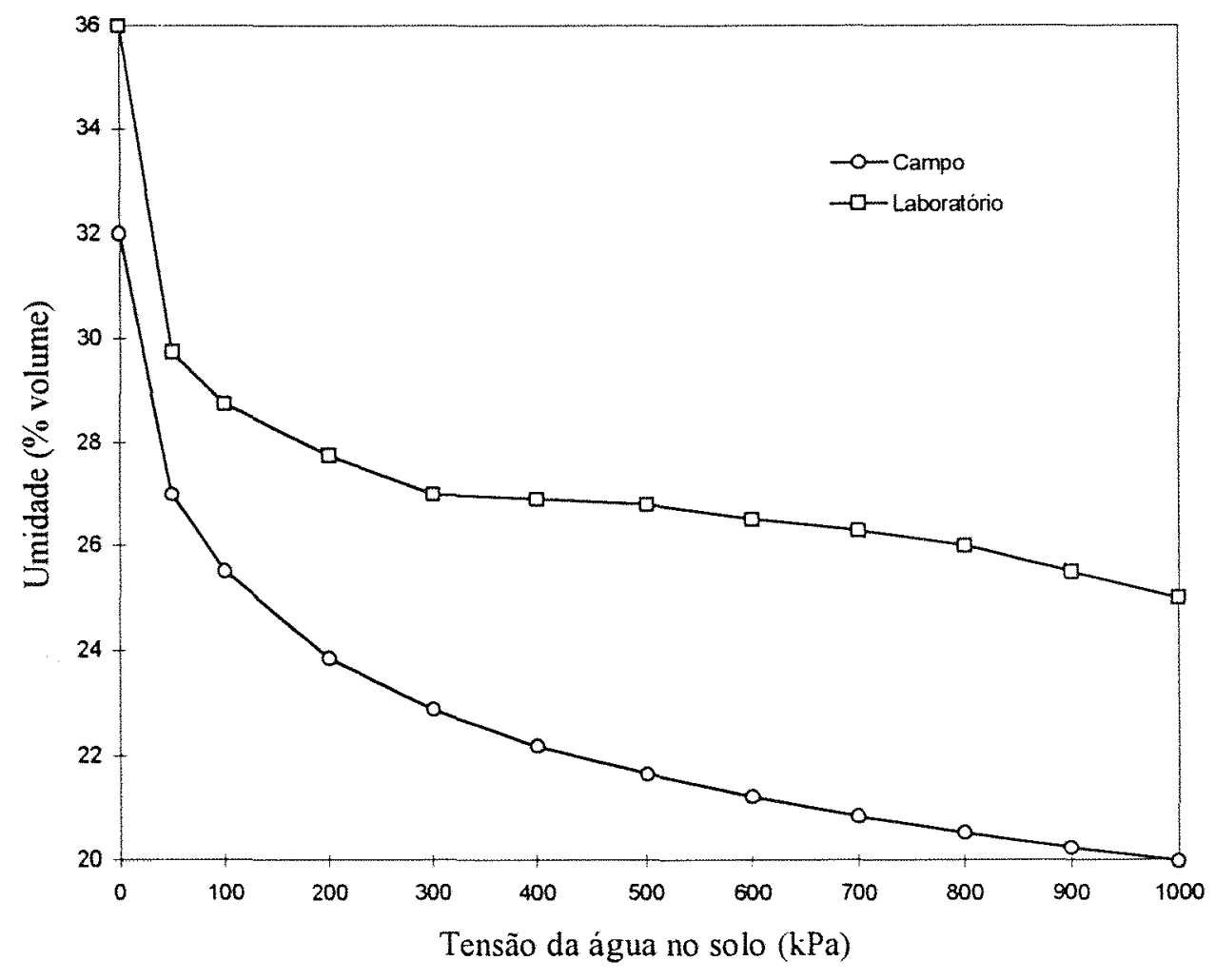

Figura 2 - Curvas de retenção da água no solo.

\subsection{Cultura e semeadura}

A cultura utilizada foi o feijoeiro (Phaseolus vulgaris L.), cultivar carioca, com ciclo de 90 dias aproximadamente. Nos dias 24, 29 e 28 de maio dos anos de 1988, 1990 e 1991, respectivamente, realizou-se a semeadura, manualmente, em sulcos espaçados de $0,50 \mathrm{~m}$, com densidade de plantio de 12 plantas por metro linear. $\mathrm{Na}$ área que circunda $\mathrm{O}$ experimento semeou-se uma faixa com 10 fileiras de plantas. Aplicou-se $50 \mathrm{~mm}$ de água parcelados em três irrigações de 15,15 e $20 \mathrm{~mm}$, com intervalo de 2 dias, para permitir a completa germinação das sementes. Após oito dias, quando $90 \%$ das plantas tinham 
emergido, procedeu-se a instalação dos tensiômetros e blocos de gesso para a medida do potencial matricial da água no solo. Durante os experimentos, realizaram-se todos os controles fitossanitários, bem como capinas e limpeza do local. Nos anos de 1988 e 1990 ocorreu leve ataque de ódio (Erysiphe poligoni) na fase reprodutiva da cultura.

\subsection{Sistema de irrigação}

O método de irrigação utilizado, foi aspersão através de tubo perfurado (Figura 3), ligado a uma caixa de cimento amianto de 1000 litros, instalada a $6 \mathrm{~m}$ de altura, ao lado do experimento. Na Figura 4 apresenta-se uma vista geral do experimento com a cultura do feijoeiro na fase de maturação. A água aplicada por irrigação foi medida por um hidrômetro com precisão de 1 litro. Foram realizados testes de uniformidade de distribuição da lâmina de água, para determinação do coeficiente de Christiansem (CUC), do coeficiente de uniformidade de distribuição (CUD), para os quais foram obtidos os valores de $90 \%$ e $88 \%$, respectivamente. A lâmina de irrigação aplicada em $\mathrm{mm} \cdot \mathrm{h}^{-1}$, foi controlada conforme abertura de um registro de gaveta situado na tubulação pouco antes do hidrômetro, de forma a não permitir erosão dentro das parcelas experimentais.

\subsection{Variáveis climáticas}

$\mathrm{Na}$ Tabela 3 apresentam-se os valores médios mensais dos parâmetros meteorológicos obtidos na estação situada a 100 metros do experimento, no período de maio a setembro, para os anos de 1988, 1990 e 1991.

No ano de 1990 houve precipitação pluvial no mês de julho nos dias 6 (38 DAS), 12,13 e 14 (46 DAS) totalizando-se $67,7 \mathrm{~mm}$ de chuva. No entanto, nos anos de $1988 \mathrm{e}$ 1991 somente a água aplicada por irrigação foi responsável pelo desenvolvimento da cultura. 


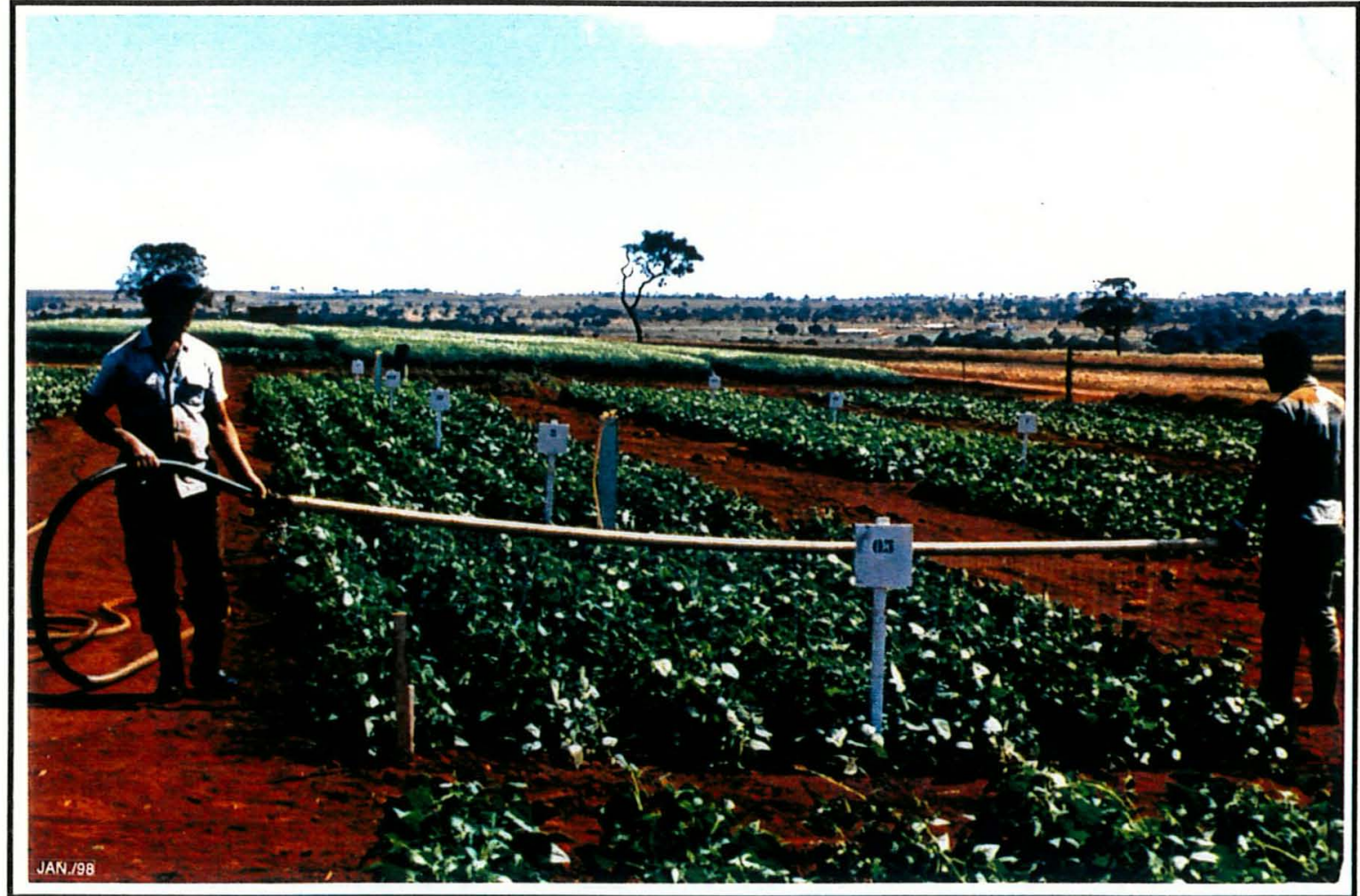

Figura 3 - Sistema de irrigação utilizado.

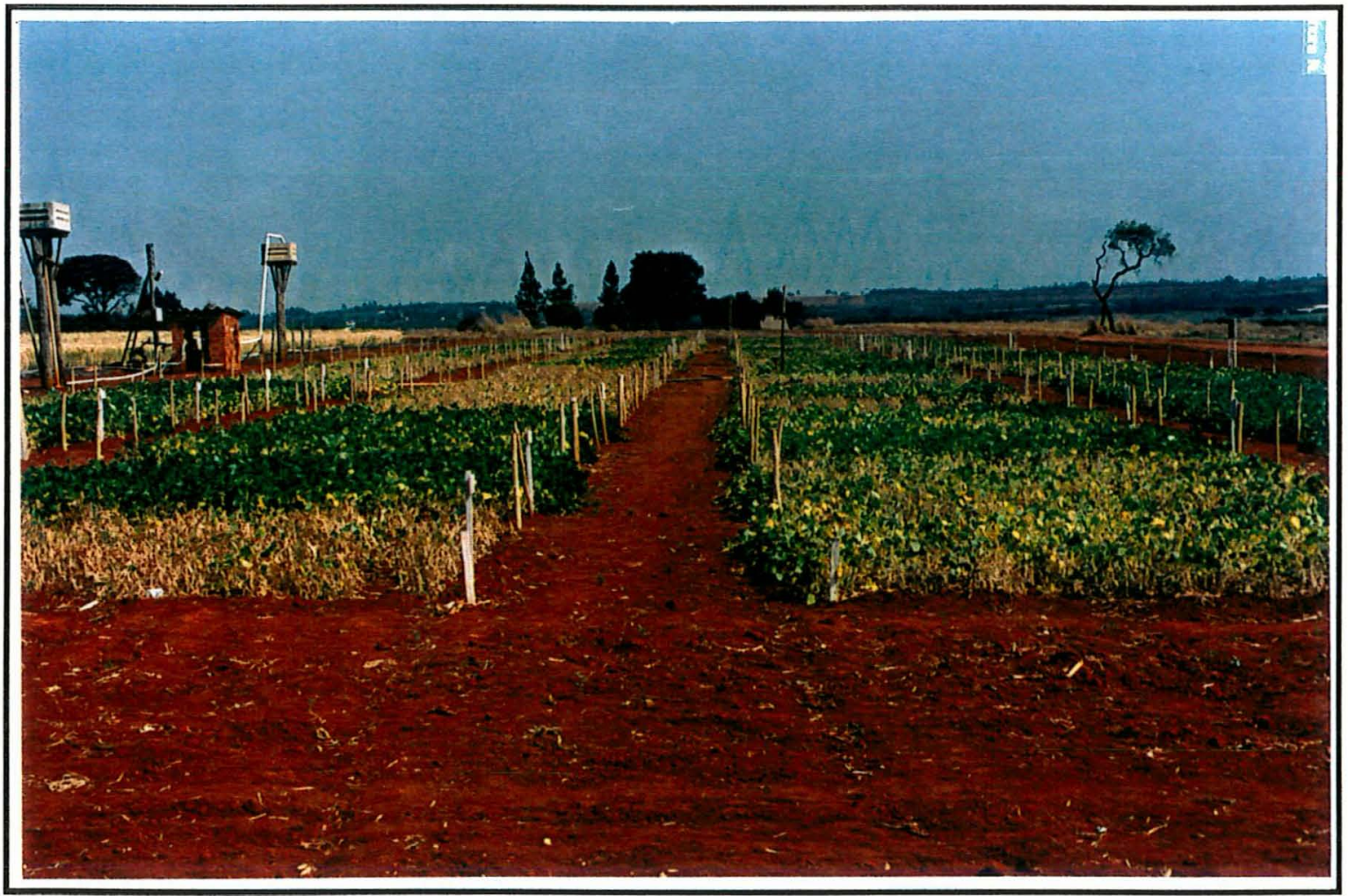

Figura 4 - Vista geral do experimento com a cultura do feijoeiro, CPAC-EMBRAPA-DF. 
Tabela 3 - Médias mensais dos parâmetros meteorológicos de maio a setembro (periodo experimental) para os anos de 1988, 1990 e 1991, CPAC-Embrapa, Planaltina - DF.

\begin{tabular}{|c|c|c|c|c|c|c|c|c|c|c|}
\hline \multirow[t]{2}{*}{ Ano } & \multirow[t]{2}{*}{ Mês } & \multirow[t]{2}{*}{$\begin{array}{l}\text { Temp. } \\
\text { do ar } \\
\left({ }^{\circ} \mathrm{C}\right)\end{array}$} & \multirow{2}{*}{$\begin{array}{l}\text { Umid. } \\
\text { rel. do } \\
\text { ar } \\
(\%)\end{array}$} & \multirow[t]{2}{*}{$\begin{array}{l}\text { Pp. } \\
\text { pluv. } \\
\text { (mm) }\end{array}$} & \multirow{2}{*}{$\begin{array}{l}\text { Evap. } \\
\text { classe } \\
\text { A } \\
(\mathrm{mm})\end{array}$} & \multirow{2}{*}{$\begin{array}{c}\text { Rad. } \\
\text { solar } \\
(\text { cal.cm } \\
\left.\text { dia }^{-1}\right)\end{array}$} & \multicolumn{4}{|c|}{$\begin{array}{l}\text { Temperatura do solo }\left({ }^{\circ} \mathrm{C}\right) \\
\text { às profundidades } \mathrm{em} \mathrm{cm}\end{array}$} \\
\hline & & & & & & & 2 & 5 & 10 & 20 \\
\hline \multirow[t]{5}{*}{1988} & 5 & 21,4 & 70 & 7,8 & 4,96 & 330 & 22,9 & 22,4 & 22,4 & 23,4 \\
\hline & 6 & 19,0 & 64 & 0,0 & 5,47 & 323 & 19,6 & 19,5 & 19,6 & 20,8 \\
\hline & 7 & 18,5 & 55 & 0,0 & 6,79 & 349 & 19,5 & 19,3 & 19,3 & 20,4 \\
\hline & 8 & 20,1 & 49 & 0,0 & 8,40 & 477 & 21,7 & 21,1 & 21,0 & 22,2 \\
\hline & 9 & 22,9 & 49 & 1,5 & 9,45 & 502 & 26,0 & 25,1 & 24,6 & 25,8 \\
\hline \multirow[t]{5}{*}{1990} & 5 & 21,4 & 72 & 148,8 & 4,77 & 426 & 22,0 & 21,6 & 21,4 & 22,5 \\
\hline & 6 & 19,8 & 61 & 0,0 & 5,35 & 446 & 19,6 & 19,3 & 19,3 & 20,5 \\
\hline & 7 & 19,7 & 65 & 67,7 & 5,38 & 364 & 18,9 & 18,7 & 18,8 & 19,8 \\
\hline & 8 & 21,1 & 67 & 12,6 & 6,48 & 511 & 21,2 & 20,6 & 20,5 & 21,4 \\
\hline & 9 & 22,6 & 66 & 95,4 & 6,78 & 508 & 23,1 & 21,8 & 21,8 & 22,8 \\
\hline \multirow[t]{5}{*}{1991} & 5 & 20,3 & 68 & 18,8 & 4,99 & 364 & 21,6 & 21,1 & 21,0 & 21,9 \\
\hline & 6 & 20,1 & 63 & 0,0 & 5,45 & 364 & 20,1 & 19,4 & 19,4 & 20,2 \\
\hline & 7 & 19,5 & 60 & 0,0 & 6,20 & 374 & 19,3 & 18,9 & 18,7 & 19,7 \\
\hline & 8 & 20,2 & 55 & 0,0 & 7,76 & 396 & 21,1 & 20,4 & 20,1 & 20,9 \\
\hline & 9 & 22,0 & 58 & 79,2 & 6,82 & 348 & 22,9 & 22,2 & 22,1 & 22,7 \\
\hline
\end{tabular}

\subsection{Controle das irrigações}

Tensiômetros e blocos de gesso (blocos de resistência elétrica) foram utilizados para fazer o controle das irrigações. Na Figura 5 apresenta-se a bateria de tensiômetros e medidor de resistência elétrica em blocos de gesso.

$\mathrm{Na}$ Figura 6 apresenta-se um bloco de gesso da marca Genuine utilizado na medição do teor de água do solo para as tensões acima de $70 \mathrm{kPa}$. 


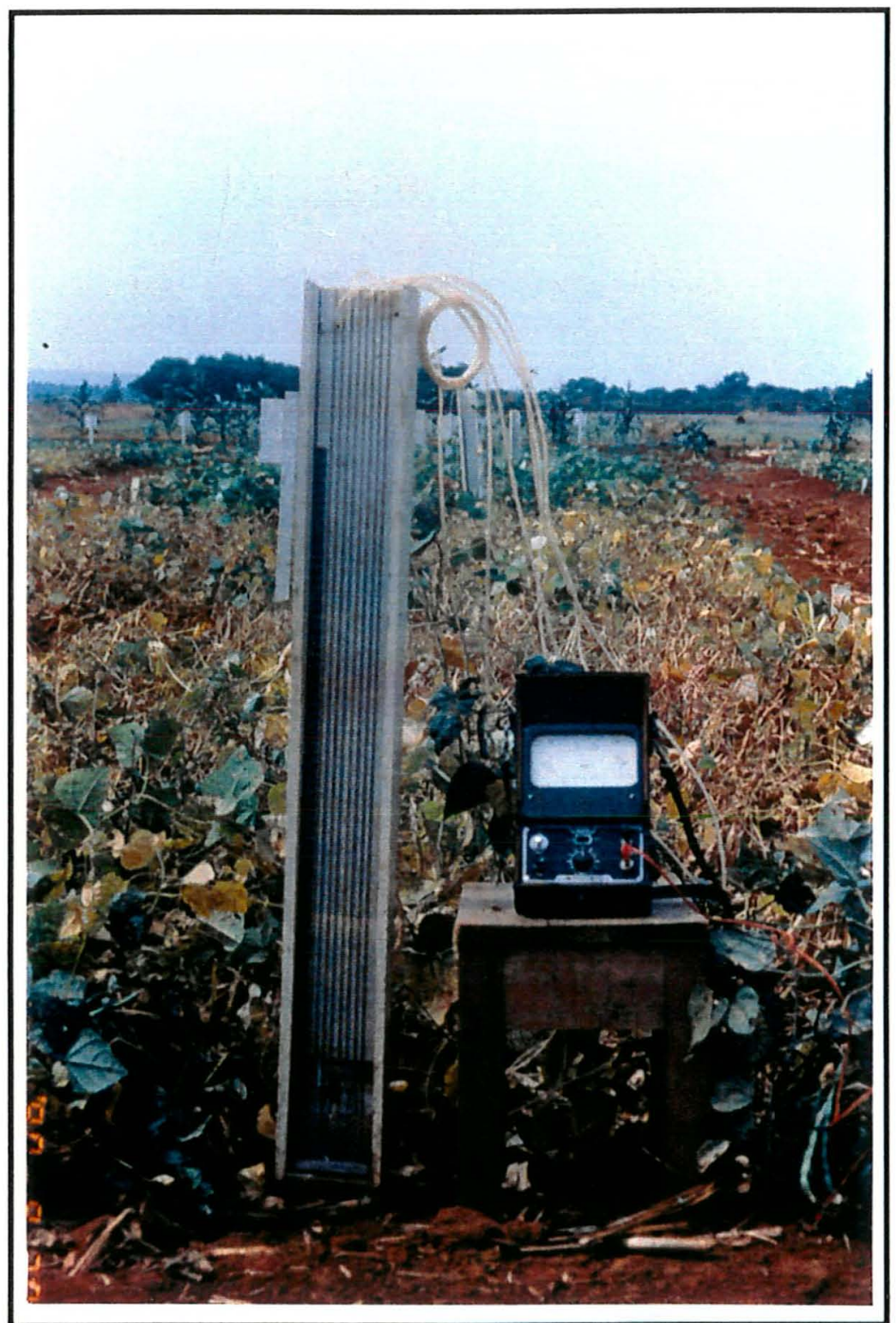

Figura 5 - Bateria de tensiômetros e medidor de resistência elétrica em bloco de gesso. 


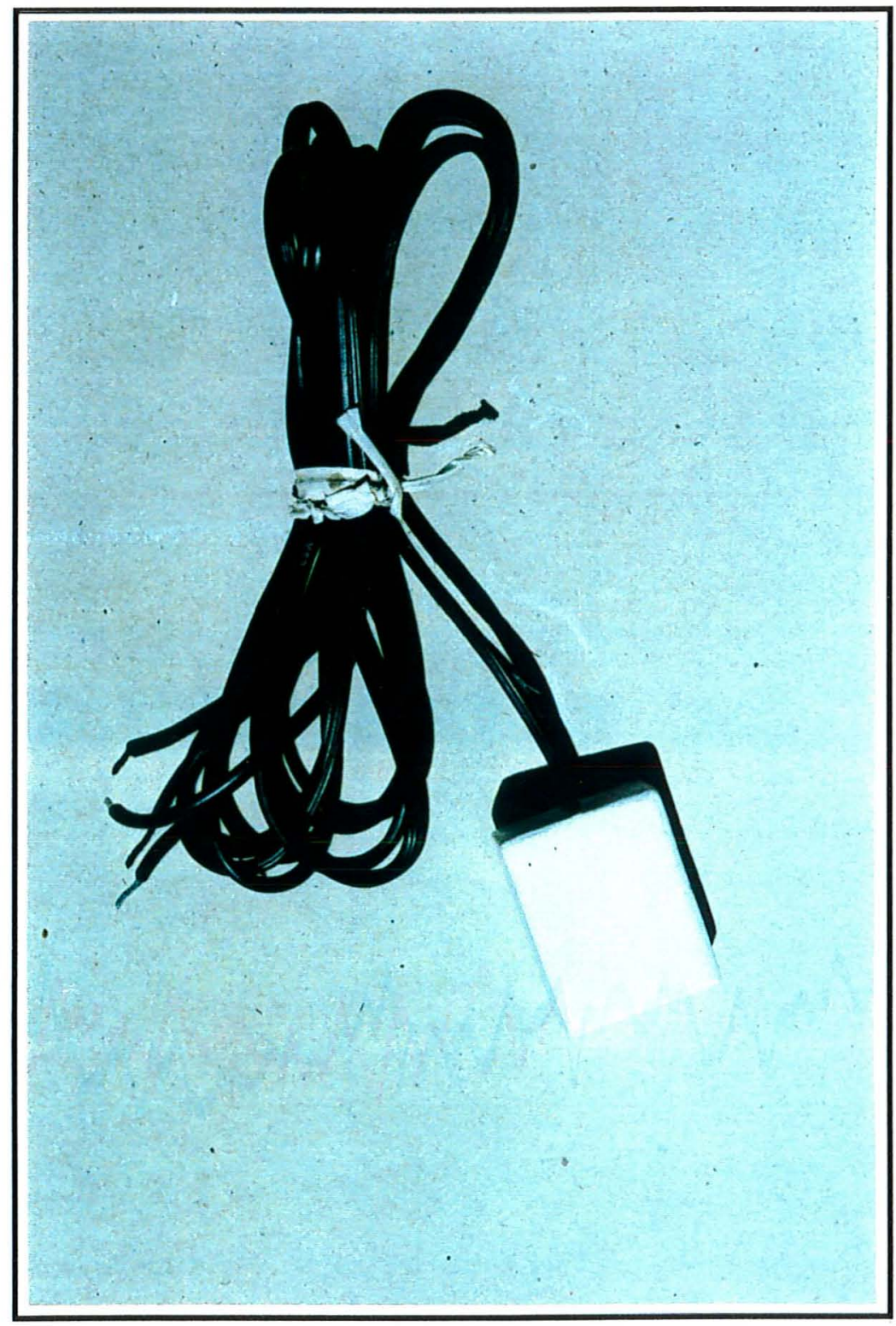

Figura 6 - Bloco de gesso (Bouyoucos), utilizado na medição do teor de água no solo. 
Uma das parcelas de cada tratamento, foi sorteada para instalação de uma bateria de tensiômetros e blocos de gesso nas profundidades de 0,$10 ; 0,20 ; 0,30 ; 0,40 ; 0,50$; 0,60 e 0,80 m (Figura 1). Os tensiômetros serviram para monitorar o momento das aplicações de água nos tratamentos de $33 \mathrm{kPa}$ (T1), $50 \mathrm{kPa}$ (T2) e $70 \mathrm{kPa}$ (T3) e os blocos de gesso para monitorar o momento das aplicações de água nos tratamentos de $100 \mathrm{kPa}(\mathrm{T} 4), 500 \mathrm{kPa}$ (T5) e $1000 \mathrm{kPa}$ (T6). Diariamente, no horário de 8:00 às 9:00 horas da manhã, foram feitas leituras dos tensiômetros e blocos de gesso, desde a fase da germinação até a de completo enchimento de grãos (75 dias após germinação aproximadamente).

O momento de irrigação para os tratamentos foi determinado quando os valores de tensão da água no solo a $10 \mathrm{~cm}$ de profundidade indicavam aproximadamente a tensão pré-estabelecida. Utilizando-se as leituras de tensão obtidas nas profundidades de 0,10 ; 0,$20 ; 0,30$ e $0,40 \mathrm{~m}$ e os respectivos teores de água no solo, calculou-se a lâmina de irrigação a ser aplicada em cada tratamento para repor a água consumida no perfil do solo $(0 \mathrm{a} 0,40 \mathrm{~m})$ à capacidade de campo $\left(0,3452 \mathrm{~cm}^{3} \cdot \mathrm{cm}^{-3}\right)$.

Na Figura 7 apresenta-se a curva de calibração de blocos para o intervalo de 4 a $1000 \mathrm{k} \Omega$. A estimativa da umidade do solo foi feita indiretamente utilizando-se os valores das leituras obtidas pelos tensiômetros e de resistência elétrica fornecidos pelos blocos de gesso. Para os tensiômetros que controlaram as irrigações até a tensão de 70 $\mathrm{kPa}$, foi utilizada a equação (1), ajustada por Miyazawa et al. (1992).

$\theta=26,509-3,479 \ln \psi, \quad R^{2}=0,9436$

em que:

$\theta=$ conteúdo de água no solo (\% volume) e $\psi$ a tensão de água no solo (atm).

Para os blocos de gesso, que controlaram as irrigações nos tratamentos com tensões acima de $70 \mathrm{kPa}(5,7 \Omega)$ utilizou-se a equação (2) para calcular a tensão da água no solo e a equação (3) para o cálculo do conteúdo de água. 
$\psi=0,2741 \Omega^{0.5374}, \mathrm{R}^{2}=0,9602$

$\theta=28,718-0,667 \ln \Omega, R^{2}=0,9254$

em que:

$\psi=$ tensão de água no solo (atm);

$\theta=$ conteúdo de água no solo (\% volume);

$\Omega$ = resistência elétrica do bloco de gesso (k-Ohms)

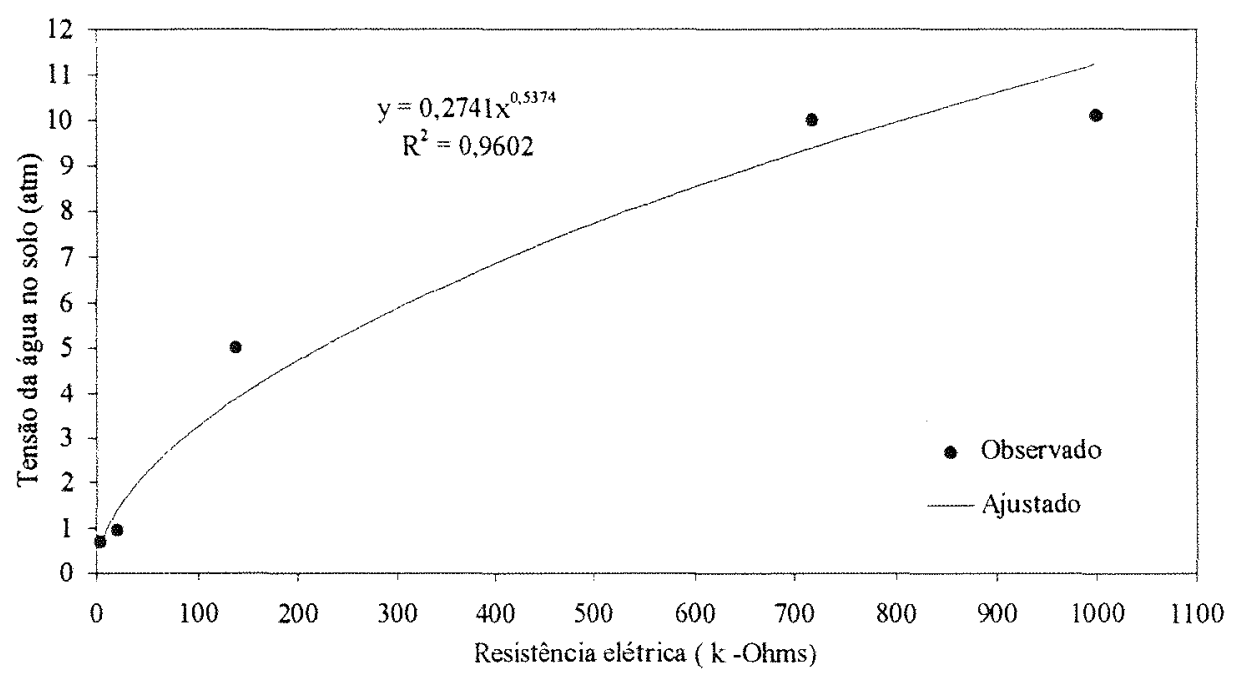

Figura 7 - Curva de calibração de blocos de gesso, para $4<$ k-Ohms $<1000$.

\subsection{Observações fenológicas}

Utilizou-se os critérios propostos por Silva (1981) e Portes (1981), fazendo-se as observações para os seis tratamentos em uma das repetições.

\subsubsection{Data da emergência}

Foi considerada como a data na qual haviam emergido $90 \%$ das plântulas, e ocorreu no $10^{\circ}$ dia após a semeadura. 


\subsubsection{Data do início da floração}

Data na qual $50 \%$ das plantas apresentaram pelo menos uma flor aberta.

\subsubsection{Data do início de enchimento de vagens}

Neste estádio, $50 \%$ das vagens apresentaram-se com sementes em crescimento. Isto foi detectado através do tato com as vagens.

\subsubsection{Data do início da maturação}

Neste estádio de desenvolvimento as plantas se apresentaram com $90 \%$ das vagens alterando-se a coloração de verde para amarelo-rosado.

Observações das fases fenológicas da cultura nos três anos de experimento, revelaram pequenas variações. Em média, a duração das fases está apresentada na Tabela 4 e Figura 8.

Tabela 4 - Duração média para os três anos das fases fenológicas da cultura do feijoeiro.

\begin{tabular}{lccc}
\hline Fases da cultura & Dias após semeadura & $\begin{array}{c}\text { Duração da fase } \\
\text { (dias) }\end{array}$ & $\begin{array}{c}\text { Duração da fase } \\
(\%)\end{array}$ \\
\hline $\begin{array}{l}\text { Semeadura à } \\
\text { emergência }\end{array}$ & 10 & 10 & 11,1 \\
$\begin{array}{l}\text { Emergência ao } \\
\text { início da floração }\end{array}$ & 40 & 30 & 33,3 \\
$\begin{array}{l}\text { Início da floração ao início } \\
\text { do enchimento de grãos }\end{array}$ & 55 & 15 & 16,7 \\
$\begin{array}{l}\text { Início do enchimento de } \\
\text { grãos ao início da maturação }\end{array}$ & 70 & 15 & 22,2 \\
$\begin{array}{l}\text { Início da maturação ao final } \\
\text { da maturação }\end{array}$ & 90 & 15 & 16,7 \\
\hline
\end{tabular}

\subsection{Rendimento da cultura}

O rendimento de grãos foi determinado em cinco fileiras de plantas centrais, totalizando $12,5 \mathrm{~m}^{2}$ de área útil em cada parcela, eliminando-se como bordadura, as duas 
linhas externas e $0,50 \mathrm{~m}$ em cada extremidade. Na fase da colheita retirou-se amostras de grãos ao acaso em diversos pontos da parcela útil e determinou-se a umidade dos grãos, a qual apresentou $16 \%$ na base úmida (bu). Mediu-se a altura de 10 plantas em cada parcela e em seguida efetuou-se a colheita manual, embalando-se as plantas em sacos de aniagem de $60 \mathrm{~kg}$, batendo-se manualmente para evitar perdas. Logo após deixou-se os grãos permanecer à luz solar até atingirem aproximadamente $13 \%$ de umidade, determinando-se a seguir o rendimento de grãos da parcela, fazendo-se quando necessário as devidas correções de umidade dos grãos para $13 \%$.

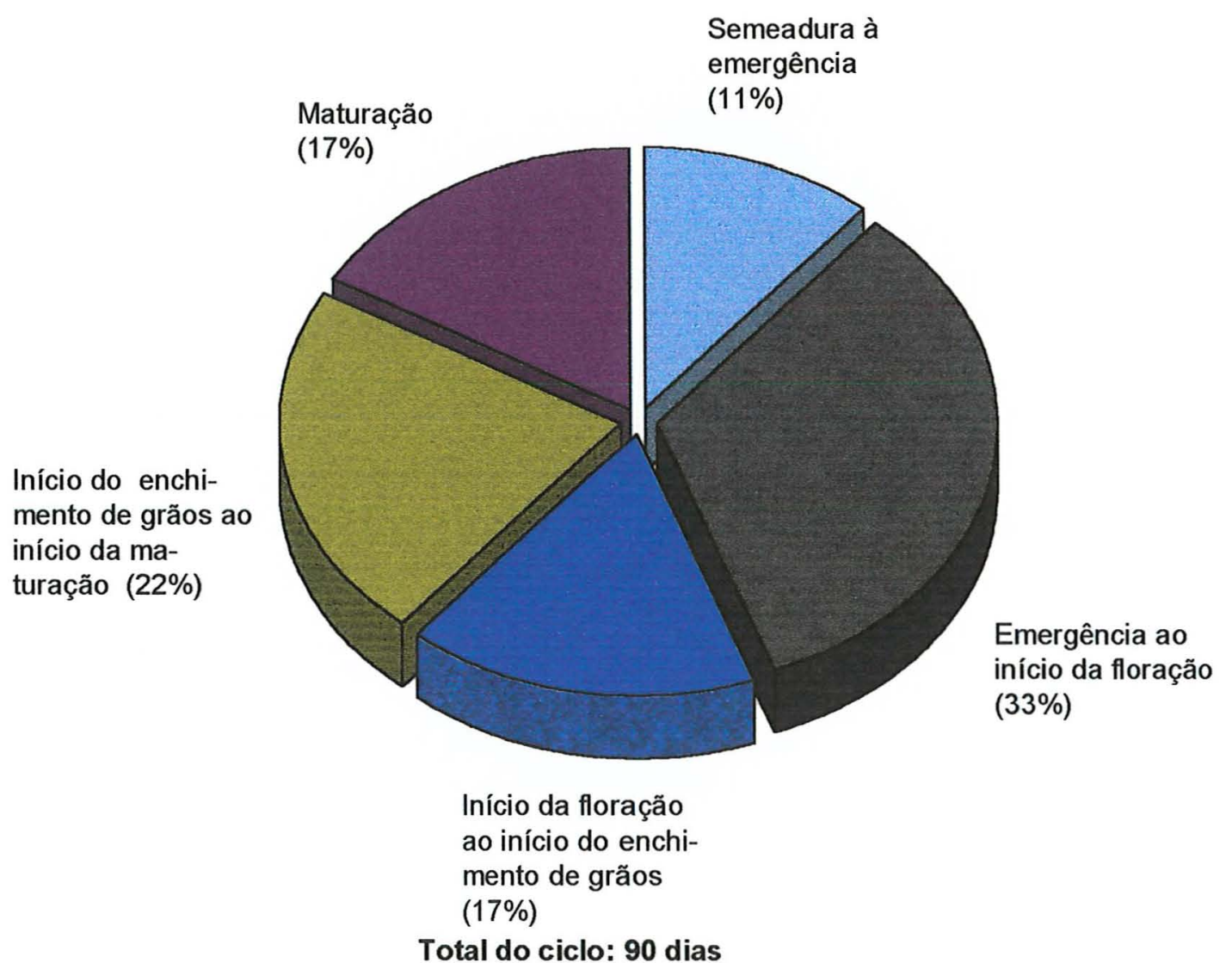

Figura 8 - Média dos três anos das fases fenológicas da cultura. 


\subsection{Componentes da produção}

Ao mesmo tempo da realização da colheita foram feitas determinações de número de vagens por planta, número de grãos por vagem e o peso de 100 grãos.

\subsubsection{Número de vagens por planta}

Retirou-se ao acaso 10 plantas da parcela útil e contou-se o número de vagens, dividindo-se este pelo número de plantas.

\subsubsection{Número de grãos por vagem}

Das 10 plantas retiradas anteriormente, contou-se o número de grãos contidos nas vagens, dividindo-se esta quantia pelo número de vagens.

\subsubsection{Peso de 100 grãos}

Retirou-se uma amostra de grãos, limpos, com umidade de $13 \%$ bu, e contou-se 100 grãos desta fazendo-se a pesagem logo após. Este mesmo procedimento foi repetido para as 24 parcelas existente no experimento.

\subsection{Eficiência de uso da água}

Considerou-se como eficiência de uso da água no campo (Ef) como a razão entre o valor do rendimento em grãos e a quantidade de água aplicada em mm, conforme Frizzone (1986).

\subsection{Análise Estatística}

$\mathrm{Na}$ análise estatística foram feitas análise da variância e de regressão e testes de significância para rendimento de grãos e componentes de produção. Utilizou-se o procedimento do Sanest - Sistema de Análise Estatística para o delineamento de blocos ao acaso. 
As variáveis medidas foram, altura de planta na colheita (ALPL) em $\mathrm{cm}$, número de vagem por planta (NVPL), número de grãos por vagem (NGV), peso de 100 grãos (P100G), em gramas. $100^{-1}$ grãos, rendimento (REND), em kg.ha ${ }^{-1}$, eficiência de uso da água (EUA), lâmina de água (LAM) e número de irrigações. A variável lâmina de água foi gerada pelo produto do número de irrigações necessárias para as diferentes tensões da água no solo e pela lâmina respectiva do tratamento.

Foram utilizados seis tratamentos representados pelas tensões da água no solo, aplicados em 4 blocos, obtendo-se, assim, para cada ano, 24 observações. O delineamento utilizado foi o de blocos ao acaso, cujo modelo matemático para análise da variância foi:

$y_{i j}=m+t_{i}+b_{j}+e_{i j}$

em que:

$\mathrm{y}_{\mathrm{ij}}$ - valor observado referente ao i-ésimo tratamento no j-ésimo bloco;

m - fator fixo, estimado pela média geral;

$t_{i}$ - efeito do i-ésimo tratamento (tensão de água no solo);

$b_{j}$ - efeito do j-ésimo bloco;

$e_{i j}$ - erro aleatório correspondentes às observações (variação do acaso sobre as observações), supostos homocedásticos, independentes e normalmente distribuídos.

A análise da variância e teste $\mathrm{F}$ foram feitas conforme esquema mostrado na Tabela 5 sendo a SQ a somas de quadrados e QM o quadrado médio. A razão QM Trat./QM Res. (valor de F) testou a hipótese $\mathrm{H}_{0}$, qual seja, de que não existe diferença entre as médias dos tratamentos. O nível mínimo de significância (n.m.s.) considerado para rejeição dessa hipótese foi de $5 \%$, ou seja, sempre que o valor da probabilidade do teste $\mathrm{F}$ for menor ou igual a $0,05(\alpha \leq 0,05)$ aceita-se que há diferença entre pelo menos duas médias de tratamento e procedeu-se então ao detalhamento da análise. 
Tabela 5 - Esquema de análise da variância e teste F para tratamentos.

\begin{tabular}{|c|c|c|c|c|}
\hline $\begin{array}{l}\text { Causas da } \\
\text { Variação }\end{array}$ & G.L. & S.Q. & Q.M. & $\mathrm{F}$ \\
\hline Blocos & 3 & SQ Blocos & QM Blocos & \\
\hline Tratamentos & 5 & SQ Trat. & QM Trat. & QM Trat./QM Res \\
\hline Resíduo & 15 & SQ Res. & QM Res. & \\
\hline Total & 23 & SQ Total & & \\
\hline
\end{tabular}

Como a tensão da água no solo no momento de irrigação é um fator quantitativo, por apresentar probabilidade zero de repetição de ocorrência de igual valor, o detalhamento da análise da variância foi feito através do estudo do comportamento das variáveis em função do aumento ou diminuição dessas tensões utilizando-se ajuste de curvas $^{1}$. Foram então ajustados os modelos linear, exponencial, logarítmico e quadrático para todas as variáveis nas quais $O$ teste $F$ detectasse diferença significativa entre as tensões, e escolhido o modelo com melhor ajuste, medido pelo coeficiente de determinação $\left(\mathrm{R}^{2}\right)$. Também foi estudado ajuste de modelo para a relação entre tensão de água no solo antes de cada irrigação e número de irrigações e relação entre lâminas aplicadas e rendimento de grãos.

\subsubsection{Análise Exploratória dos Dados}

Para validade dos modelos de análise descritos as seguintes pressuposições devem ser satisfeitas:

- homogeneidade de variâncias, ou seja, só podem ser comparados tratamentos com variâncias homogêneas entre si;

- independência dos erros;

- erros com distribuição normal (ou aproximadamente normal).

\footnotetext{
' Não pode ser utilizado para esse caso testes qualitativos para escolher "a melhor" ou "a pior" tensão da água no solo, pois como pode ser observado na descrição do experimento, no momento de irrigação é impossivel se repetir o mesmo nivel anterior.
} 
Para testar essas pressuposições procedeu-se à análise exploratória de dados, utilizando-se testes de homogeneidade de variância, análise gráfica dos resíduos e diagrama de ramos e folhas.

\subsubsection{Teste de homogeneidade de variâncias}

Utilizou-se o teste do Fmáx, que consiste em obter a razão entre a maior e a menor variância de tratamentos (para cada variável) e compará-la com um valor tabelado:

$$
F_{\text {max }}=\frac{s_{\text {max }}^{2}}{s_{\text {min }}^{2}} \sim F_{(k, v-1)}
$$

sendo $k$ o número de tratamentos e $v$-1 o grau de liberdade.

Se o valor obtido for maior que o tabelado, rejeita-se a hipótese de que as variâncias de tratamentos são homogêneas, havendo necessidade de se estudar se essa heterogeneidade pode ser eliminada com uma transformação dos dados ou não. Se o valor obtido for menor que o tabelado, não se rejeita a hipótese de homogeneidade de variâncias.

\subsubsection{Análise gráfica dos resíduos}

A análise gráfica de resíduos utilizada consiste em plotar num diagrama de dispersão os valores estimados pelo modelo da análise da variância em função dos resíduos padronizados (erro referente a cada observação dividido pelo desvio padrão amostral). A forma desse gráfico permite a detecção da falta de independência e existência de heterogeneidade regular (que pode ser eliminada através do uso de uma transformação adequada) ou irregular que não permite transformação. O intervalo dos resíduos padronizados detecta se há algum(ns) valor(es) desviando-se da normalidade. Consideram-se normalmente distribuídos os resíduos que estiverem no intervalo de -3 a 3 . 


\subsubsection{Diagrama de "ramos e folhas"}

Utilizou-se o diagrama de "ramos e folhas" que consiste na ordenação dos dados de forma programada para mostrar sua distribuição aproximada, dispersão, assimetria, curtose, agrupamento de valores e, principalmente, detecção de "outliers" (dados discrepantes) e sua localização espacial, alertando para possíveis problemas não observados durante o experimento (Hoaglin, Mosteller e Tukey, 1992). 


\section{RESULTADOS E DISCUSSÃO}

\subsection{Resultados gerais do experimento}

As tensões médias do limite superior observadas para início das irrigações foram diferentes dos valores preestabelecidos, o que pode ser verificado na Tabela 6 , sendo esse um dos fatores que não possibilitou analisar-se conjuntamente os dados obtidos nos três anos. Esses valores, medidos a $10 \mathrm{~cm}$ de profundidade ao longo do ciclo da cultura, e que foram usadas para indicar o momento das irrigações nos tratamentos correspondentes as tensões pré-estabelecidas, tiveram variação 36 a $917 \mathrm{kPa}$ para o ano de 1988, de 38 a 994 $\mathrm{kPa}$ para 1990 e de 37 a $990 \mathrm{kPa}$ para 1991. Em geral foram superiores aos valores préestabelecidos, até o tratamento T4, com excessão do tratamento T3. Para os tratamentos $\mathrm{T} 5$ e $\mathrm{T} 6$, as tensões da água no solo foram mais baixas do que os valores preestabelecidos.

Tabela 6 - Médias das tensões da água no solo do limite superior para início das irrigações, em $\mathrm{kPa}$, observadas durante o ciclo da cultura, e respectivos desvios padrões (entre parênteses).

\begin{tabular}{cccccccc}
\hline \multirow{2}{*}{ Tratamentos } & $\begin{array}{c}\text { Tensão preesta- } \\
\text { belecida (kPa) }\end{array}$ & \multicolumn{5}{c}{$\begin{array}{c}\text { Tensão observada } \\
\text { (kPa) }\end{array}$} \\
\cline { 3 - 8 } & & \multicolumn{2}{c}{1988} & \multicolumn{1}{c}{1990} & & 1991 \\
\hline T1 & 33 & 36 & $(6,96)$ & 38 & $(4,94)$ & 37 & $(11,25)$ \\
T2 & 50 & 49 & $(8,11)$ & 56 & $(6,50)$ & 57 & $(7,10)$ \\
T3 & 70 & 68 & $(7,75)$ & 63 & $(11,42)$ & 69 & $(7,56)$ \\
T4 & 100 & 154 & $(15,67)$ & 169 & $(35,46)$ & 140 & $(12,28)$ \\
T5 & 500 & 361 & $(103,40)$ & 464 & $(132,81)$ & 458 & $(114,39)$ \\
T6 & 1000 & 917 & $(33,31)$ & 994 & $(88,51)$ & 990 & $(48,50)$ \\
\hline
\end{tabular}


Durante o ciclo da cultura foram obtidos valores médios de tensão de água no solo, da superficie à profundidade de $80 \mathrm{~cm}$. Com base nas Tabelas 21, 22 e 23 do Anexo I é possível observar que houve decréscimo desses valores médios a medida que se aumentou a profundidade das leituras dos equipamentos instalados em campo, demonstrando um comportamento diferente, no que refere-se a extração de água, para cada camada ao longo do perfil.

Nas Figuras 9 e 10 mostra-se um exemplo da variação temporal da tensão da água no solo, para os diferentes tratamentos, utilizando-se os dados do ano de 1988. Nessas figuras também pode-se visualizar o número de irrigações realizadas, e os períodos em que ocorreram os déficits hídricos, além da linha média dos limites superiores para início das irrigações. Quanto menor o limite superior para que fossem iniciadas as irrigações, mais freqüentes foram as mesmas, menores foram os picos, sendo a tensão da água no solo mantida dentro de uma faixa mais estreita.

A média das lâminas de cada irrigação realizada para os três anos é apresentada na Tabela 7, apresentando valores claramente diferentes entre os três anos. Esse é um dos fatores que proporcionou valores diferentes do número de irrigações necessárias. Sendo importante ressaltar que nas médias apresentadas, não foram considerados os $50 \mathrm{~mm}$ aplicados durante a fase de emergência, porém no cálculo das lâminas totais este valor foi considerado.

Na Tabela 8 são apresentados os resultados obtidos no experimento conduzido nos anos de 1988, 1990 e 1991. Mesmo nos tratamentos submetidos ao déficit hídrico, os de rendimento de grãos, apresentaram valores superiores àqueles relatados por Teixeira el al. (1978), na ordem de $1500 \mathrm{~kg} \cdot \mathrm{ha}^{-1}$ e Almeida et al. (1990), com $1033 \mathrm{~kg} \cdot \mathrm{ha}^{-1}$ nos quais os autores mencionam como produtividade mínima para viabilizar, economicamente a implantação da cultura sob irrigação. As produtividades encontradas neste experimento confirmam, que é possivel obter altas produções do feijoeiro, quando forem utilizadas tecnologias adequadas que levem em conta os fatores importantes que mais influenciam no rendimento da cultura, entre os quais se inclui a irrigação. 

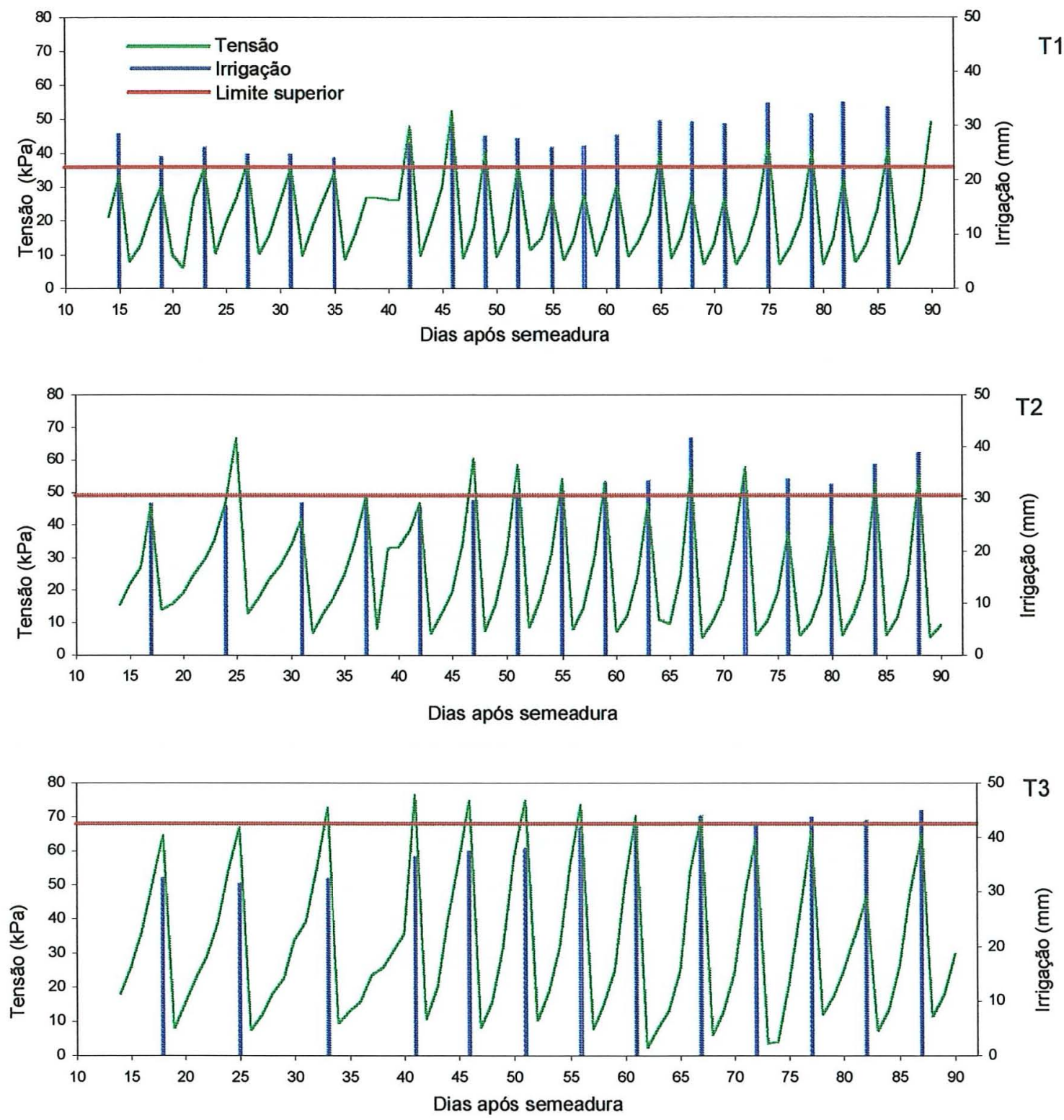

Figura 9 - Variação temporal da tensão da água no solo $(10 \mathrm{DAS}=03 / 06 / 1988)$, obtidas por tensiômetros, para os tratamentos de $36 \mathrm{kPa}$ (T1), $49 \mathrm{KPa}$ (T2) e $68 \mathrm{kPa}$ (T3), com as respectivas lâminas de água aplicadas e limite superior para início da irrigação, para o ano de 1988. 

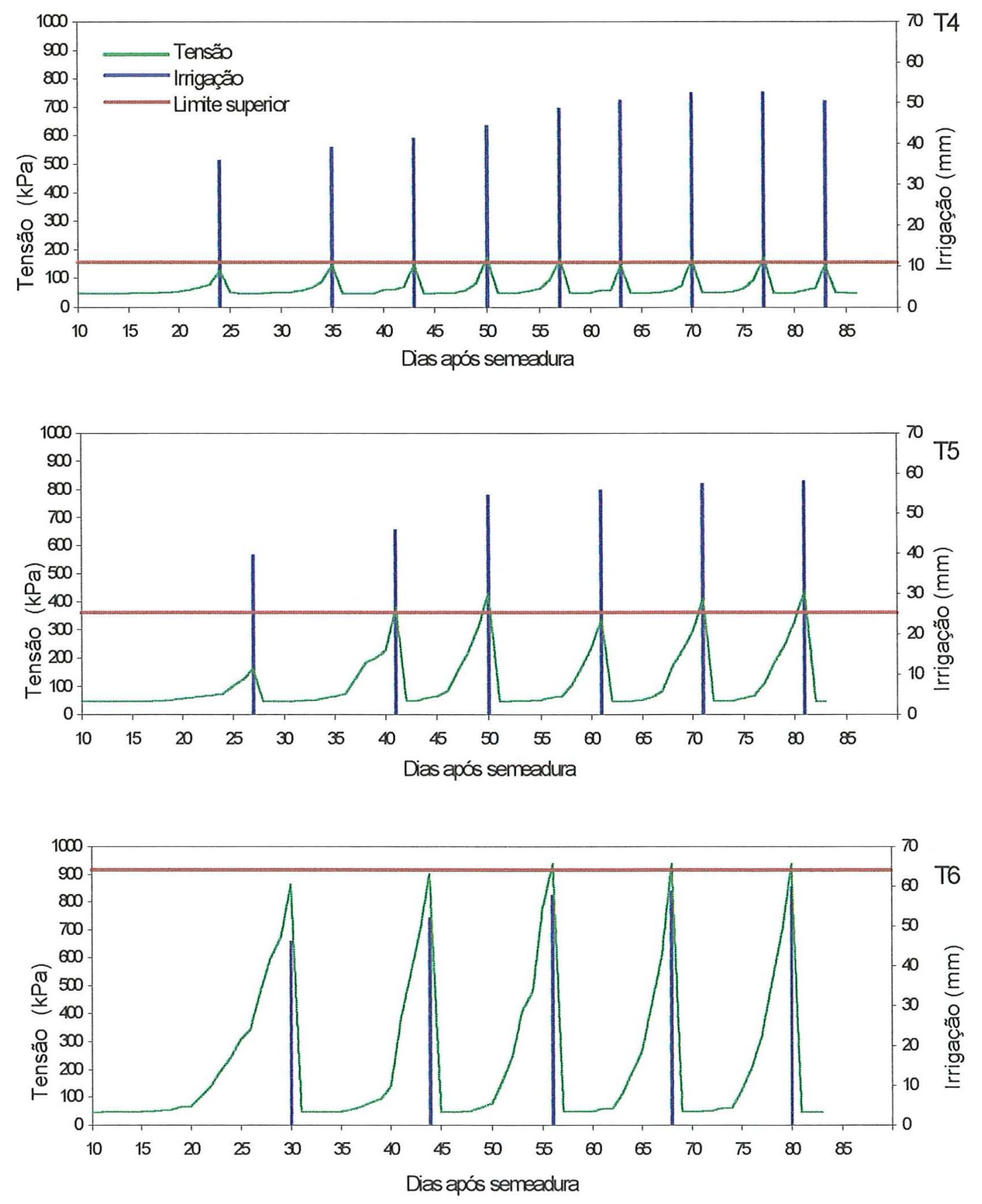

Figura 10 - Variação temporal da tensão da água no solo (10 DAS= 03/06/1988)., obtidas por blocos de gesso, para os tratamentos de $154 \mathrm{kPa}$ (T4), $36 \mathrm{kPa}$ (T5) e $917 \mathrm{kPa}$ (T6), com as respectivas lâminas de água aplicadas e limite superior para início da irrigação, para o ano de 1988. 
Tabela 7 - Médias das lâminas de água aplicadas em cada irrigação com desvio padrão entre parênteses.

\begin{tabular}{ccccccc}
\hline \multirow{2}{*}{ Tratamento } & \multicolumn{6}{c}{ Lâmina (mm) } \\
\cline { 2 - 7 } 1988 & \multicolumn{5}{c}{1990} & \\
\hline T1 & 28,64 & $(3,29)$ & 14,65 & $(4,22)$ & 21,22 & $(4,48)$ \\
T2 & 30,66 & $(6,16)$ & 19,94 & $(3,47)$ & 23,10 & $(2,73)$ \\
T3 & 39,27 & $(4,82)$ & 24,30 & $(5,90)$ & 23,55 & $(3,87)$ \\
T4 & 46,20 & $(6,25)$ & 33,16 & $(4,42)$ & 29,33 & $(5,30)$ \\
T5 & 51,85 & $(7,46)$ & 35,88 & $(1,48)$ & 43,15 & $(2,71)$ \\
T6 & 54,85 & $(5,67)$ & 34,53 & $(1,59)$ & 40,68 & $(4,87)$ \\
\hline
\end{tabular}

Os tratamentos com tensões maiores ( $\mathrm{T} 5$ e $\mathrm{T} 6$ ) foram afetados com maior intensidade quanto à produtividade da cultura, comprometendo-a por situarem-se as fases decisivas entre os largos intervalos entre irrigações, pois a redução da produtividade esta intimamente relacionada com o número de dias de deficiência hídrica, sendo a redução tão mais acentuada, quanto mais crítica for a fase (Magalhães \& Millar, 1988). Como exemplo, o inicio da fase reprodutiva é considerada uma das fases da cultura mais críticas quando há falta de água. $\mathrm{Na}$ floração a falta de água provoca queda das vagens e diminuição do tamanho destas (Fancelli \& Dourado Neto, 1990). Em fases mais adiantadas quando já se encontra definido o tamanho das vagens, os déficits hídricos, entre os largos intervalos entre as irrigações podem ocasionar redução no tamanho e no peso dos grãos. 
Tabela 8 - Resultados gerais do experimento.

\begin{tabular}{|c|c|c|c|c|c|c|c|c|c|c|}
\hline Anos & $\begin{array}{c}\text { T. preest. } \\
\text { (Trat) }\end{array}$ & $\begin{array}{l}\text { Tens. } \\
(\mathrm{kPa})\end{array}$ & $\begin{array}{l}\text { ALPL } \\
(\mathrm{cm})\end{array}$ & $\begin{array}{c}\text { NVPL } \\
-\end{array}$ & $\begin{array}{c}\text { NGV } \\
-\end{array}$ & $\begin{array}{c}\text { P100G } \\
(\mathrm{g})\end{array}$ & $\begin{array}{l}\text { REND } \\
\left(\mathrm{kg} \cdot \mathrm{ha}^{-1}\right)\end{array}$ & $\begin{array}{l}\text { LAM } \\
(\mathrm{mm})\end{array}$ & $\begin{array}{l}\mathrm{N}^{\circ} \text { de } \\
\text { irrig }\end{array}$ & $\begin{array}{c}\text { EUA } \\
\left(\mathrm{kg} \cdot \mathrm{mm}^{-1}\right)\end{array}$ \\
\hline & $33(\mathrm{~T} 1)$ & 36 & 44,60 & 9,37 & 5,77 & 24,92 & 2945,75 & 623 & 20 & 4,73 \\
\hline & $50(\mathrm{~T} 2)$ & 49 & 41,65 & 10,97 & 5,70 & 24,40 & 2973,50 & 571 & 17 & 5,21 \\
\hline & 70 (T3) & 68 & 49,85 & 9,47 & 5,52 & 24,15 & 2775,75 & 561 & 13 & 4,95 \\
\hline \multirow[t]{7}{*}{1988} & $100(\mathrm{~T} 4)$ & 154 & 46,97 & 11,15 & 5,50 & 24,52 & 2865,50 & 466 & 9 & 6,15 \\
\hline & 500 (T5) & 361 & 35,30 & 8,32 & 5,47 & 24,80 & 2171,50 & 361 & 6 & 6,01 \\
\hline & $1000(\mathrm{~T} 6)$ & 917 & 38,37 & 7,40 & 5,35 & 25,15 & 2152,25 & 324 & 5 & 6,64 \\
\hline & Teste F & - & ns & * & ns & ns & $* *$ & - & - & ** \\
\hline & $33(\mathrm{Tl})$ & 38 & 42,00 & 14,30 & 5,52 & 23,47 & 3021,75 & 528 & 28 & 5,72 \\
\hline & $50(\mathrm{~T} 2)$ & 56 & 41,10 & 13,80 & 5,10 & 22,95 & 2866,75 & 556 & 22 & 5,15 \\
\hline & $70(\mathrm{~T} 3)$ & 63 & 41,65 & 13,15 & 4,97 & 22,25 & 2760,25 & 458 & 14 & 6,02 \\
\hline \multirow[t]{7}{*}{1990} & $100(\mathrm{~T} 4)$ & 169 & 44,90 & 16,15 & 4,62 & 19,00 & 2399,75 & 383 & 8 & 6,26 \\
\hline & 500 (T5) & 464 & 41,42 & 15,45 & 3,95 & 19,25 & 1995,0 & 333 & 6 & 5,99 \\
\hline & $1000(\mathrm{~T} 6)$ & 994 & 41,25 & 15,65 & 3,67 & 20,47 & 2210,00 & 325 & 6 & 6,80 \\
\hline & Teste F & - & ns & ns & $* *$ & ** & $* *$ & - & - & ** \\
\hline & $33(\mathrm{Tl})$ & 37 & 43,90 & 16,35 & 5,35 & 24,00 & 3320,00 & 602 & 26 & 5,51 \\
\hline & $50(\mathrm{~T} 2)$ & 57 & 44,80 & 16,80 & 5,05 & 23,02 & 3038,25 & 581 & 23 & 5,23 \\
\hline & $70(\mathrm{~T} 3)$ & 69 & 46,60 & 16,80 & 5,45 & 23,37 & 3011,00 & 474 & 18 & 6,35 \\
\hline \multirow[t]{4}{*}{1991} & $100(\mathrm{~T} 4)$ & 140 & 41,40 & 16,60 & 5,22 & 23,87 & 3168,00 & 469 & 14 & 6,75 \\
\hline & 500 (T5) & 458 & 40,25 & 12,20 & 5,37 & 21,65 & 2600,50 & 352 & 7 & 7,39 \\
\hline & $1000(\mathrm{~T} 6)$ & 990 & 38,00 & 11,40 & 4,95 & 23,77 & 2452,25 & 335 & 7 & 7,32 \\
\hline & Teste F & - & * & * & ns & ** & ** & - & - & ** \\
\hline
\end{tabular}

ns: não significativo, ao nível de $5 \% ;{ }^{*} e^{* *}$; significativo aos niveis de $5 \%$ e $1 \%$, respectivamente.

Legenda:

ALPL - Altura de planta

NVPL - Número de vagem por planta

NGV - Número de grãos por vagem

P100G - Peso de 100 grãos

REND - Rendimento de grãos

LAM - Lâmina aplicada

EUA - Eficiência de uso da água 
Utilizando-se os resultados da Tabela 8 e fazendo-se uma comparação conjunta dos 3 anos entre os tratamentos T1 e T6 pode-se observar que a tensão média de água no solo no momento da irrigação foi de $37 \mathrm{kPa}$ para o $\mathrm{T} 1$ e $967 \mathrm{kPa}$ para o T6, que acarretou um decréscimo médio de 18,7 irrigações entre os dois tratamentos. Quanto a lâmina aplicada, ocorreu uma redução média de $256,3 \mathrm{~mm}$ no valor total, resultando numa redução no rendimento de $824 \mathrm{~kg} \cdot \mathrm{ha}^{-1}$ entre os tratamentos T1 e T6.

As lâminas totais diminuiram com o aumento da tensão de água no solo e o número de irrigações decresceram com o aumento da tensão da água no solo, o que se esperava ocorrer. Sendo assim, a lâmina total foi maior nos tratamentos irrigados nas tensões observadas a $36 \mathrm{kPa}(\mathrm{T} 1)$ em 1988, $38 \mathrm{kPa}$ (T1) em 1990 e $37 \mathrm{kPa}$ (T1) em 1991. Foram obtidos menores valores para as tensões $917 \mathrm{kPa}$ (T6), $994 \mathrm{kPa}$ (T6) e 990 $\mathrm{kPa}$ (T6) respectivamente nos três anos do experimento. O valor dessas laminas correspondem ao somatório das irrigações individuais, contantes no Anexo I (Tabelas 21, 22 e 23), mais 50 mm das irrigações para a germinação.

\subsection{Análise estatística}

\subsubsection{Análise exploratória dos dados}

$O$ valor tabelado do teste de $F_{\text {max }}$ para 6 tratamentos e 4 blocos permitiria uma razão entre a maior e menor variância de até 62. Todas as variáveis, nos três anos apresentaram valores menores que esse, indicando que em nenhuma situação ocorreu falta de homogeneidade de variâncias.

A análise dos resíduos, cujos gráficos se encontram no Anexo II (Figuras 22, 23 e 24), permite afirmar que as pressuposições de independência (através da forma do gráfico), de normalidade (através dos intervalos dos resíduos padronizados) e também de homogeneidade de variâncias (já verificada pelo teste anterior) não foram violadas.

A observação dos diagramas de ramos e folhas, constante no Anexo III (Tabela 24), permite a visualização de "outliers" (observações discrepantes) apenas nas variáveis NGV-91 e P100G-91. As observações discrepantes encontradas para o NVG-91 foram 
para menor referentes às parcelas $\mathrm{B} 2 \mathrm{~T} 2, \mathrm{~B} 2 \mathrm{~T} 6$ e $\mathrm{B} 4 \mathrm{~T} 6$; e para maior para a parcela B1T3. A observação discrepante na variável P100G-91, foi para menor referente a parcela B1T5. Já que todas as observações discrepantes foram detectadas no ano de 1991, e nos blocos 1 e 2, com exceção da parcela B4T6, pode ter ocorrido variações não controladas nessas parcelas. Observe-se, entretanto, que a existência desses "outliers" não violou as pressuposições para análise da variância e testes para inferência.

\subsubsection{Análise da variância e de regressão}

As análises da variância para as variáveis altura de planta, número de vagem por planta, número de grãos por vagem, peso de 100 grãos, rendimento de grãos e eficiência de uso de água , para os anos de 1988, 1990 e 1991 são apresentadas a seguir ${ }^{2}$. Para os anos em que o teste $\mathrm{F}$ foi significativo ao nivel de $5 \%$, procedeu-se o detalhamento da análise, onde são apresentadas as equacões que tiveram um melhor ajuste. Os comportamentos apresentados são mostrados nas figuras, sendo somente apresentadas as funções cujo ajuste foi significativo pelo teste $F$.

Para as variáveis, número de irrigações aplicadas, lâminas totais, e a relação entre rendimento de grãos em função das lâminas totais, não foi possível o procedimento de análise de variância e Teste F por não ter-se repeticões, já que as lâminas aplicadas foram as mesmas em todos os blocos, por terem sido realizadas ao mesmo tempo. Portanto, os valores das lâminas totais e o número de irrigações foram os mesmos em todas as repetições dentro de cada tratamento. Porém, mesmo assim, foi feito estudo de ajuste de curvas e apresentação do comportamento através de figuras.

\footnotetext{
${ }^{2}$ Serão apresentados na tabela de análise da variância apenas os graus de liberdade e os quadrados médios, já que as somas de quadrados relativas podem ser obtidas pela multiplicação dos GL $\times$ QM e 0 valor do teste $\mathrm{F}$ calculados pela divisão do QM Trat./QM Res.
} 


\subsubsection{Altura de plantas}

Observa-se na Tabela 9 que houve diferença significativa entre tratamentos apenas no ano de 1991, apesar de que em todos os anos os tratamentos com menores tensões apresentarem tendência a maiores alturas de plantas. O comportamento da cultura indicou sensibilidade da altura de plantas quanto a condição de tensão de água no solo aplicada, sendo esta variável importante em se tratando de colheita mecanizada. Resultados semelhantes foram encontrados por Parjol (1976). As médias obtidas encontram-se nas Tabelas 8 e 10. Foi ajustada para o ano de 1991 a equação 6 mostrando comportamento logarítmico entre altura de planta na colheita em função dos níveis de tensão da água no solo. A Figura 11 mostra o comportamento dessa variável no ano de 1991.

$\hat{Y}=53,457-2,2038 \ln \psi, \quad \mathrm{R}^{2}=79,72(\%)$

em que:

$\hat{Y}$ - altura de planta na colheita $\mathrm{em} \mathrm{cm}$.

$\psi$ - tensão da água no solo, em kPa, tal que $37 \mathrm{kPa} \leq \psi \geq 990$.

Tabela 9 - Análise da variância e teste $F$ para tratamentos (tensão da água no solo), para a variável altura de planta na colheita, nos anos de 1988, 1990 e 1991.

\begin{tabular}{lcccc}
\hline Causas da variação & G.L. & \multicolumn{3}{c}{ QUADRADOS MÉDIOS } \\
\cline { 3 - 5 } & & 1988 & 1990 & 1991 \\
\hline Blocos & 3 & 13,5004 & 14,9683 & 18,9170 \\
Tratamentos & 5 & $118,0207^{\text {ns }}$ & $8,1748^{\text {ns }}$ & $40,4659^{*}$ \\
Resíduo & 15 & 44,3116 & 10,5361 & 12,3278 \\
Total & 23 & & & \\
\hline
\end{tabular}

* - Significativo, pelo teste $\mathrm{F}$, ao nivel de $5 \%$.

$n s=$ Não significativo. pelo teste F, considerando-se um n.m.s. de $5 \%$. 
Tabela 10 - Altura de plantas (cm) em função da tensão da água no solo nos anos de 1988, 1990 e 1991.

\begin{tabular}{ccccccc}
\hline Tratamentos & \multicolumn{2}{c}{1988} & \multicolumn{2}{c}{1990} & \multicolumn{2}{c}{1991} \\
\cline { 2 - 7 } & Tensão & Médias & Tensão & Média & Tensão & Média \\
\hline T1 & 36 & 44,60 & 38 & 42,00 & 37 & 43,90 \\
T2 & 49 & 41,65 & 56 & 41,10 & 57 & 44,80 \\
T3 & 68 & 49,85 & 63 & 41,65 & 69 & 46,60 \\
T4 & 154 & 46,97 & 169 & 44,90 & 140 & 41,40 \\
T5 & 361 & 35,30 & 464 & 41,42 & 458 & 40,25 \\
T6 & 917 & 38,37 & 994 & 41,25 & 990 & 38,00 \\
\hline
\end{tabular}

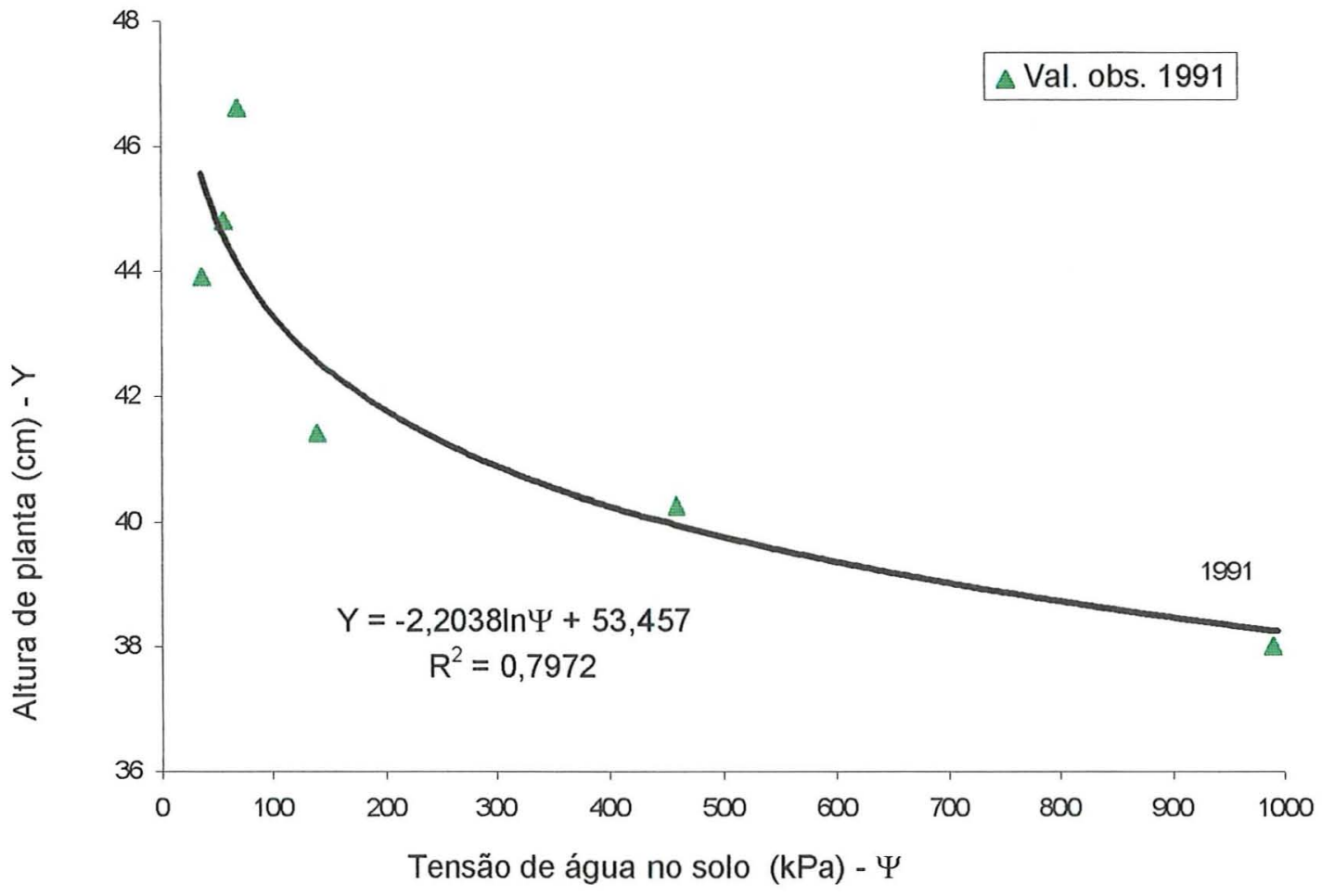

Figura 11 - Altura de planta na colheita em função da tensão da água no solo. 


\subsubsection{Número de vagens por planta}

Os tratamentos apresentaram diferenças significativas nos anos de 1988 e de 1991 (Tabela 11), o mesmo não ocorrendo para o ano de 1990, quando os diferentes níveis de tensão não provocaram diferentes resultados quanto ao número de vagem por planta. As médias obtidas encontram-se nas Tabelas 8 e 12 .

No ano de 1990 os níveis de tensão de água no solo não apresentaram diferenças significativas, sendo que uma possivel explicação para este comportamento, é o fato de terem ocorrido chuvas num total de $67,7 \mathrm{~mm}$, entre os $38^{\circ}$ e $46^{\circ}$ dia após a semeadura, que coincidiram com a fase inicial de florescimento, onde ocorre a definição do número de vagens a ser produzida pela planta. Com isso ocorreram menores déficits hídricos que o esperado nos tratamentos com as tensões maiores, possibilitando que os mesmos produzissem um número maior de vagens. Isso verifica-se mais claramente na Tabela 12 , onde nos anos de 1988 e 1991 houve redução dos valores desta variável nos tratamentos T5 e T6, o que não ocorreu para o ano de 1990. Isso concorda com Pozzebon (1995) que também encontrou que estresse hídrico reduziu o número de vagens por planta. Vieira et al. (1989) e Costa et al. (1991) verificaram que o maior esgotamento hídrico do solo ocorre no estádio de formação das vagens.

Tabela 11 - Análise da variância e teste F para tratamentos (tensão da água no solo), para a variável número de vagem por planta, nos anos de 1988, 1990 e 1991.

\begin{tabular}{lcccc}
\hline Causas da variação & G.L. & \multicolumn{3}{c}{ QUADRADOS MÉDIOS } \\
\cline { 3 - 5 } & & 1988 & 1990 & 1991 \\
\hline Blocos & 3 & 1,6522 & 4,3266 & 4,3750 \\
Tratamentos & 5 & $8,5520^{*}$ & $5,5340^{\text {ns }}$ & $25,3269^{*}$ \\
Residuo & 15 & 2,7336 & 3,8173 & 6,1830 \\
Total & 23 & & & \\
\hline
\end{tabular}

* Significativo, pelo testa $F$, ao nivel de $5 \%$.

ns $=$ Não significativo, pelo teste $F$, considerando-se um n.m.s. de $5 \%$. 
Tabela 12 - Número de vagens por planta em função da tensão da água no solo nos anos de 1988,1990 e 1991.

\begin{tabular}{ccccccc}
\hline Tratamentos & \multicolumn{2}{c}{1988} & \multicolumn{2}{c}{1990} & \multicolumn{2}{c}{1991} \\
\cline { 2 - 7 } & Tensão & Média & Tensão & Média & Tensão & Média \\
\hline T1 & 36 & 9,375 & 38 & 14,300 & 37 & 16,350 \\
T2 & 49 & 10,975 & 56 & 13,800 & 57 & 16,800 \\
T3 & 68 & 9,475 & 63 & 13,150 & 69 & 16,800 \\
T4 & 154 & 11,150 & 169 & 16,150 & 140 & 16,600 \\
T5 & 361 & 8,325 & 464 & 15,450 & 458 & 12,200 \\
T6 & 917 & 7,400 & 994 & 15,650 & 990 & 11,400 \\
\hline
\end{tabular}

As equações 7 e 8 foram ajustadas para número de vagem por planta, nos anos de 1988 e 1991, respectivamente, em função dos níveis de tensão da água no solo, sendo que em ambas o melhor ajuste foi o logarítmico. A Figura 12 mostra o comportamento dessa variável para os 2 anos.

$$
\begin{aligned}
& \hat{Y}=10,331-0,0033 \psi, \quad \mathrm{R}^{2}=60,88 \% \\
& \hat{Y}=24,046-1,813 \ln \psi, \quad \mathrm{R}^{2}=86,20 \%
\end{aligned}
$$

em que:

$\hat{Y}$ - número de vagem por planta.

$\psi$ - tensão da água no solo, em $\mathrm{kPa}$, tal que $36 \mathrm{kPa} \leq \psi \geq 917$, em 1988 e $37 \mathrm{kPa} \leq \psi$ $\geq 990$, em 1991 . 


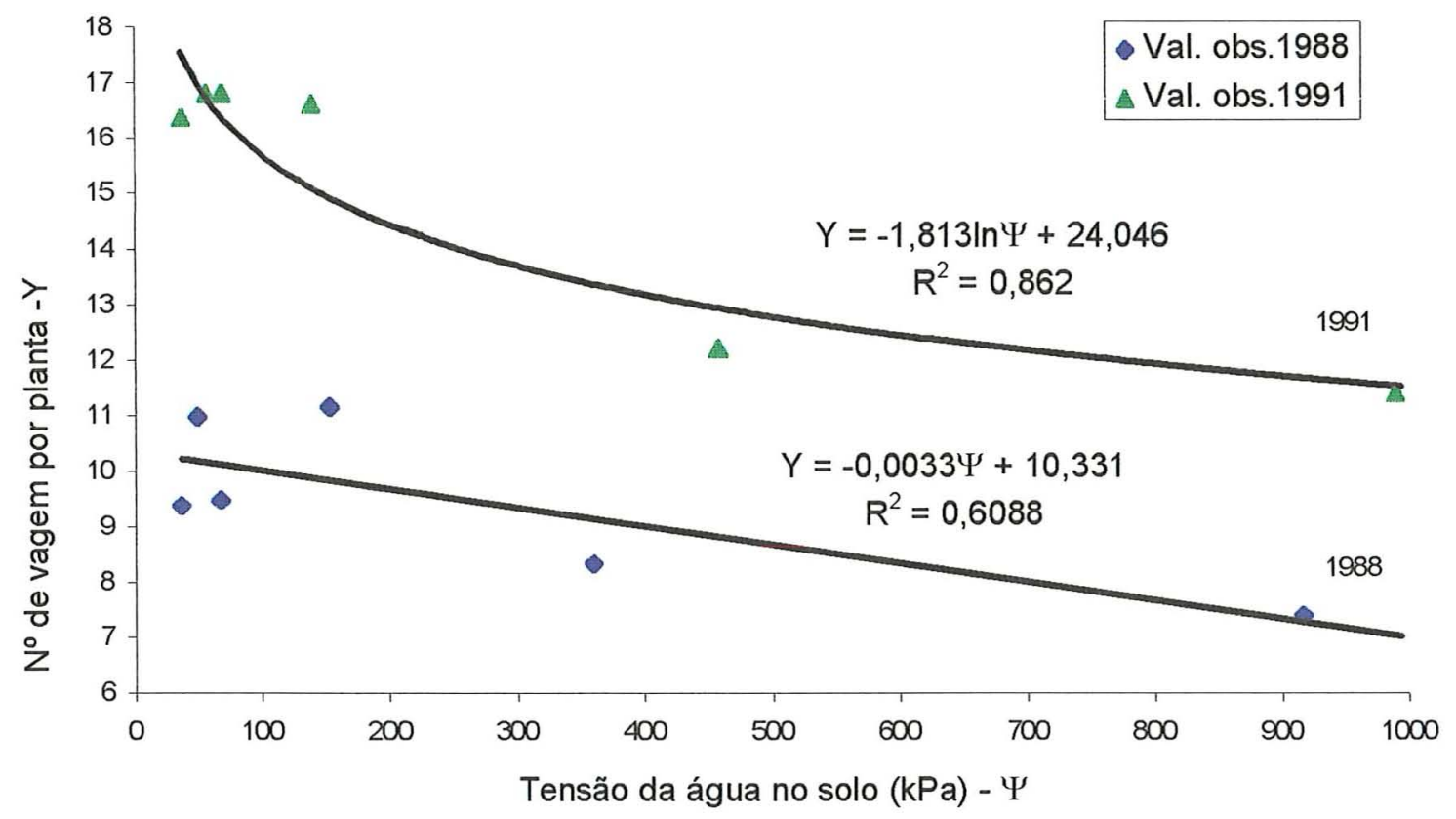

Figura 12 - Número de vagem por planta em função da tensão da água no solo.

\subsubsection{Número de grãos por vagem}

A análise da variância (Tabela 13) mostrou diferenças significativas entre tratamentos apenas no ano de 1990, ou seja, os diferentes níveis de tensão da água no solo não provocaram diferentes resultados quanto ao número de grãos por vagem nos anos de 1988 e 1991, Frizzone (1986) e Favaro \& Pilatti (1987) também encontraram que o número de grãos por vagens é influenciado pela tensão da água no solo. 
Tabela 13 - Análise da variância e teste F para tratamentos (tensão da água no solo), para a variável número de grãos por vagem, nos anos de 1988, 1990 e 1991.

\begin{tabular}{lcccc}
\hline Causas da variação & G.L. & \multicolumn{3}{c}{ QUADRADOS MÉDIOS } \\
\cline { 3 - 5 } & & 1988 & 1990 & 1991 \\
\hline Blocos & 3 & 0,0204 & 0,1394 & 0,1944 \\
Tratamentos & 5 & $0,0974^{\text {ns }}$ & $2,0117^{* *}$ & $0,1557^{\text {ns }}$ \\
Resíduo & 15 & 0,0581 & 0,1534 & 0,1141 \\
Total & 23 & & & \\
\hline
\end{tabular}

** = Significativo, pelo teste $\mathrm{F}$, ao nivel de $1 \%$.

ns $=$ Não significativo, pelo teste F, considerando-se um n.m.s. de $5 \%$.

As médias obtidas encontram-se na Tabela 8 e 14, nas quais percebe-se que o comportamento dessa variável foi contrário ao apresentado para o número de vagens por planta, ocorrendo diferenças significativas apenas para o ano de 1990.

Tabela 14 - Número de grãos por vagem em função da tensão da água no solo nos anos de 1988,1990 e 1991

\begin{tabular}{ccccccc}
\hline Tratamentos & \multicolumn{2}{c}{1988} & \multicolumn{2}{c}{1990} & \multicolumn{2}{c}{ 1991 } \\
\cline { 2 - 7 } & Tensão & Média & Tensão & Média & Tensão & Média \\
\hline T1 & 36 & 5,775 & 38 & 5,525 & 37 & 5,350 \\
T2 & 49 & 5,700 & 56 & 5,100 & 57 & 5,050 \\
T3 & 68 & 5,525 & 63 & 4,975 & 69 & 5,450 \\
T4 & 154 & 5,500 & 169 & 4,625 & 140 & 5,225 \\
T5 & 361 & 5,475 & 464 & 3,950 & 458 & 5,375 \\
T6 & 917 & 5,350 & 994 & 3,675 & 990 & 4,950 \\
\hline
\end{tabular}

Este comportamento pode ser explicado devido a planta ter produzido maior número de vagem nos tratamentos T5 e T6, pela ocorrência de chuvas no ano de 1990, na fase de início de florescimento, conforme visto no item anterior. No entanto na fase 
posterior, não se beneficiaram de suprimento hídrico adequado, para possibilitar o enchimento das vagens, por terem esses tratamentos sido irrigados à tensões maiores, conseqüentemente apresentaram menor número de grãos por vagem e também como será visto no próximo item, menor peso de grãos. Isto evidencia a capacidade de compensação fisiológica da cultura entre os diferentes componentes do rendimento.

A equação 9 foi ajustada para o ano de 1990, mostrando comportamento logarítmico para o número de grãos por vagem em função dos níveis de tensão da água no solo. A Figura 13 mostra o comportamento dessa variável para o ano de 1990.

$\hat{Y}=7,333-0,538 \ln \psi, \quad \mathrm{R}^{2}=97,80 \%$

em que:

$\hat{Y}$ - número de grãos por vagem.

$\psi$ - tensão da água no solo, em $\mathrm{kPa}$, tal que $38 \mathrm{kPa} \leq \psi \geq 994$.

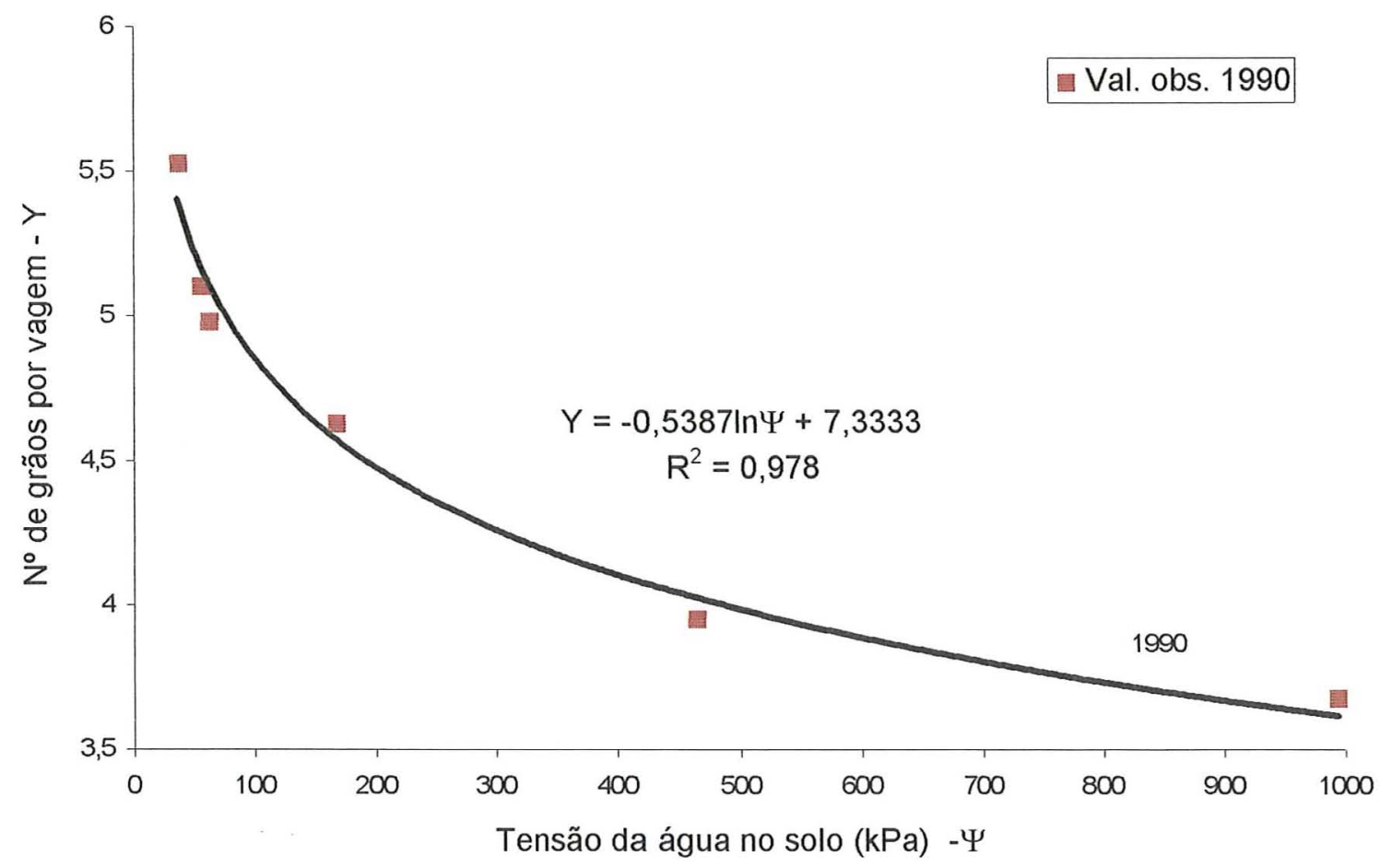

Figura 13 - Número de grãos por vagem em função da tensão de água no solo. 


\subsubsection{Peso de 100 grãos}

Observa-se, pela Tabela 15, que houve diferença significativa para a variável peso de 100 grãos entre tratamentos para os anos de 1990 e de 1991, o mesmo não ocorrendo para o ano de 1988, quando os diferentes níveis de tensão de tensão da água no solo não provocaram diferenças. As médias obtidas encontram-se na Tabela 8 e 16.

Tabela 15 - Análise da variância e teste $\mathrm{F}$ para tratamentos (tensão da água no solo), para a variável peso de 100 grãos (g), nos anos de 1988, 1990 e 1991.

\begin{tabular}{lcccl}
\hline Causas da variação & G.L. & \multicolumn{3}{c}{ QUADRADOS MÉDIOS } \\
\cline { 3 - 5 } & & 1988 & 1990 & 1991 \\
\hline Blocos & 3 & 0,5561 & 0,3943 & 0,4901 \\
Tratamentos & 5 & $0,5405^{\text {ns }}$ & $14,8016^{* *}$ & $3,0785^{* *}$ \\
Residuo & 15 & 0,7858 & 2,0775 & 0,3460 \\
Total & 23 & & & \\
\hline
\end{tabular}

** = Significativo, pelo teste $\mathrm{F}$, ao nivel de $1 \%$.

ns $=$ Não significativo, pelo teste $F$, considerando-se um n.m.s. de $5 \%$.

Tabela 16 - Peso de 100 grãos $(\mathrm{g})$ em função da tensão da água no solo nos anos de 1988,1990 e 1991.

\begin{tabular}{ccccccc}
\hline \multirow{2}{*}{ Tratamentos } & \multicolumn{2}{c}{1988} & \multicolumn{2}{c}{1990} & \multicolumn{2}{c}{1991} \\
\cline { 2 - 7 } & Tensão & Média & Tensão & Média & Tensão & Média \\
\hline T1 & 36 & 24,925 & 38 & 23,475 & 37 & 24,000 \\
T2 & 49 & 24,400 & 56 & 22,950 & 57 & 23,025 \\
T3 & 69 & 24,150 & 63 & 22,250 & 69 & 23,375 \\
T4 & 154 & 24,525 & 169 & 19,000 & 140 & 23,875 \\
T5 & 361 & 24,800 & 464 & 19,250 & 458 & 21,650 \\
T6 & 917 & 25,150 & 994 & 20,475 & 990 & 23,775 \\
\hline
\end{tabular}

Para essa variável o melhor ajuste encontrado foi o quadrático, e não o logarítmico, para os anos de 1990 e 1991. Porém são apresentadas apenas apenas as equações logarítmicas, pois ficaria dificil explicar uma função quadrática, com ponto crítico para este tipo de fenômeno. As equações ajustadas para peso de 100 grãos em 
função dos níveis de tensão de água no solo foram as equações 10 e 11 respectivamente para os anos de 1990 e 1991, sendo o comportamento mostrado na Figura 14.

$\hat{Y}=26,889-1,132 \ln \psi, \quad \mathrm{R}^{2}=58,68 \%$

$\hat{Y}=24,338-0,212 \ln \psi, \quad \mathrm{R}^{2}=9,70 \%$

em que:

$\hat{Y}$ - peso de 100 grãos em g.

$\psi$ - tensão da água no solo, em kPa, tal que $38 \mathrm{kPa} \leq \psi \geq 994 \mathrm{kPa}$, em 1990 e $37 \mathrm{kPa} \leq$ $\psi \geq 990 \mathrm{kPa}$, em 1991 .

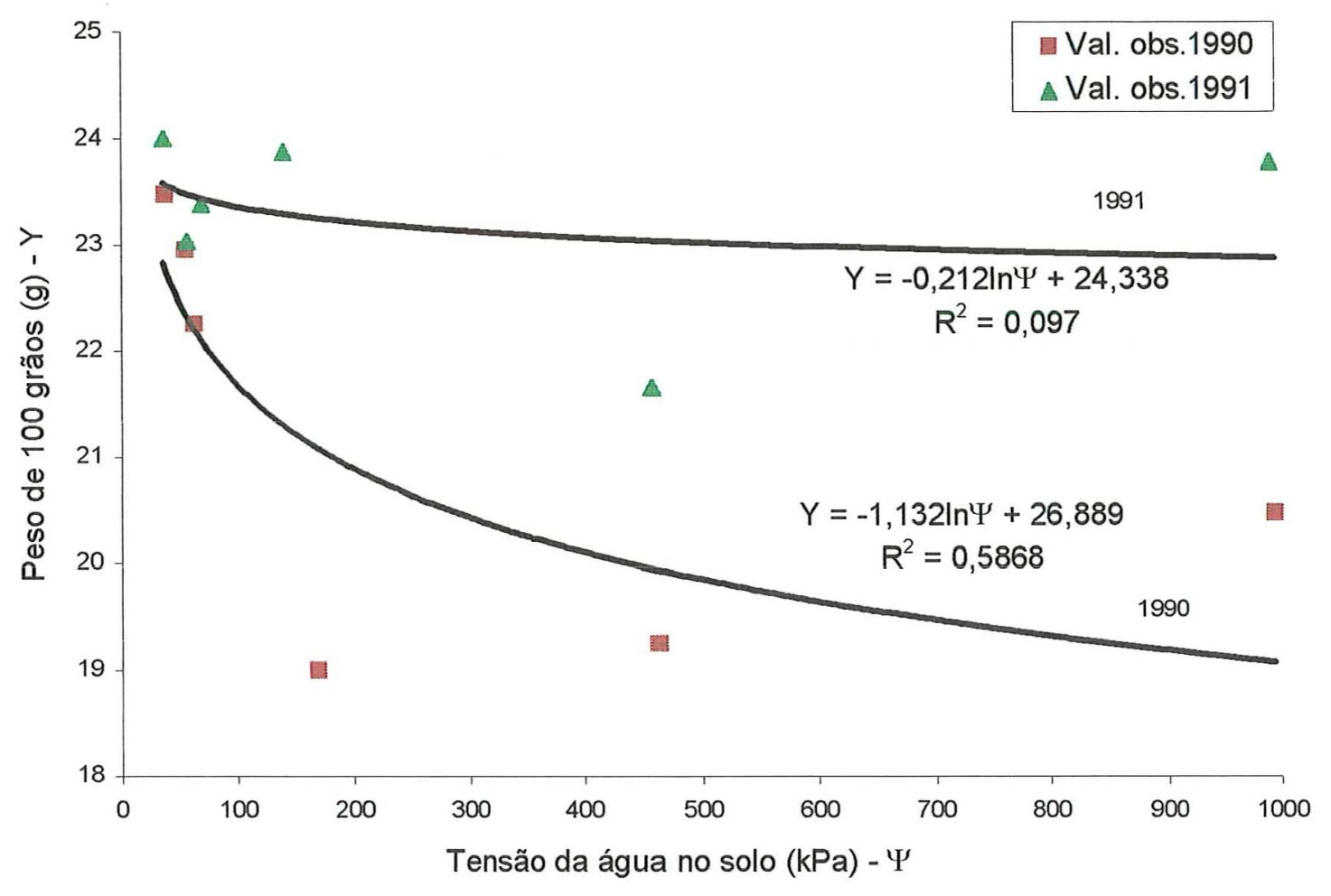

Figura 14 - Peso de 100 grãos em função da tensão da água no solo. 
Uma possivel explicação para os baixos valores dos coeficientes de determinação das duas equações logarítmicas e do melhor ajuste quadrático pode ser pela capacidade de compensação fisiológica entre os componentes do rendimento ao longo do ciclo da planta, levando-se em consideração que as deficiências hídricas podem ter ocorrido em diferentes fases fenológicas para cada tratamento de tensão da água no solo. Assim, para os tratamentos com menores tensões de água no solo, as plantas manifestaram o seu potencial máximo tanto para o número de grãos por planta, número de grãos por vagem e peso de 100 grãos. Nas tensões intermediárias, houve a formação de número de vagem por planta e do número de grãos por vagens até um valor potencial máximo para as condições de tensão da água no solo oferecidas às plantas, porém devido a ocorrência de déficit hídrico, em fases posteriores, as plantas não conseguiram encher totalmente os grãos anteriormente formados. Para as tensões mais elevadas (T5 e T6), ocorreram limitações na formação do número de vagens e número de grãos, o que veio a limitar o número total de grãos formados, assim, na fase de enchimento de grãos, as plantas tiveram condições de encher os grãos, até maiores valores do que as tensões intermediárias, mesmo sob condições de déficits hídricos maiores. Dessa forma explicando o aparecimento de ponto de mínimo para esta variável.

Resultados apresentados por Couto (1979) afirmam que o déficit hídrico reduz o peso das sementes. Porém Robins et al. (1967) menciona que podem ocorrer aumentos de peso dos grãos, para compensar reduções do número de vagens e grãos por vagem. Observando-se a Tabela 18, percebe-se que quando ocorreram valores baixos de número de vagem por planta e número de grãos por vagem os valores para o peso de 100 grãos se comportaram de maneira inversa, mostrando a capacidade de compensação da planta ao longo do ciclo.

A explicação acima torna o problema mais complexo, pois além dos valores das tensões existem os efeitos das épocas em que ocorrem os déficits hidricos entre os picos de tensão da água no solo. Isso pode ser confirmado para o ano de 1988, pela Figura 9 e 10 onde verifica-se que os tratamentos irrigados à tensões maiores apresentaram largos 
períodos de déficit hídricos, onde as fases criticas da cultura poderiam estar situadas, permitindo assim, a compensação fisiológica nas fases subseqüentes. Sem dúvida, isto diminui o valor das equações ajustadas.

\subsubsection{Rendimento de grãos}

$\mathrm{Na}$ Tabela 17, pode-se observar que houve diferença significativa entre tratamentos para o rendimento, em kg.ha ${ }^{-1}$, nos três anos estudados. As médias obtidas encontram-se na Tabela 8 e 18 , verificando-se que os rendimentos diminuiram para os valores de tensão da água no solo, entre a maior e menor produção na ordem de $27,7 \%$; $26,8 \%$ e 26,1\%, para os anos de 1988, 1990 e 1991, respectivamente, corroborando com os valores apresentados por Frizzone (1986) nos quais os rendimentos foram $90 \%$ superiores quando o manejo das irrigações situou-se entre os potenciais matriciais de - 0,5 bar (tensão de $50 \mathrm{kPa}$ ) e -2,0 bar (tensão de $200 \mathrm{kPa}$ ).

Tabela 17 - Análise da variância e teste F para tratamentos (tensão da água no solo), para a variável rendimento, em kg.ha ${ }^{-1}$, nos anos de 1988, 1990 e 1991.

\begin{tabular}{lcccc}
\hline Causas da variação & G.L. & \multicolumn{3}{c}{ QUADRADOS MÉDIOS } \\
\cline { 3 - 5 } & & 1988 & 1990 & 1991 \\
\cline { 2 - 4 } Blocos & 3 & 98851,5417 & 19752,8333 & 61841,7778 \\
Tratamentos & 5 & $584839,6750^{* *}$ & $650338,7000^{* *}$ & $451057,3667^{* *}$ \\
Residuo & 15 & 58628,0417 & 36939,5000 & 72898,4778 \\
Total & 23 & & & \\
\hline
\end{tabular}

** = Significativo, pelo teste $\mathrm{F}$, ao nivel de $1 \%$ $n s=$ Não significativo. pelo teste $F$, considerando-se um n.m.s. de 5\%. 
Tabela 18 - Rendimentos de grãos $\left(\mathrm{kg} \cdot \mathrm{ha}^{-1}\right)$ em função da tensão da água no solo nos anos de 1988,1990 e 1991.

\begin{tabular}{ccccccc}
\hline Tratamentos & \multicolumn{2}{c}{1988} & \multicolumn{2}{c}{1990} & \multicolumn{2}{c}{ 1991 } \\
\cline { 2 - 7 } & Tensão & Média & Tensão & Média & Tensão & Média \\
\hline T1 & 36 & 2945,75 & 38 & 3021,75 & 37 & 3320,00 \\
T2 & 49 & 2973,50 & 56 & 2866,75 & 57 & 3038,25 \\
T3 & 68 & 2775,75 & 63 & 2760,25 & 69 & 3011,00 \\
T4 & 154 & 2865,50 & 169 & 2399,75 & 140 & 3168,00 \\
T5 & 361 & 2171,50 & 464 & 1995,00 & 458 & 2600,50 \\
T6 & 917 & 2152,25 & 994 & 2210,00 & 990 & 2452,25 \\
\hline
\end{tabular}

Foram ajustadas as equações 12,13 e 14 para rendimento, em $\mathrm{kg} \cdot \mathrm{ha}^{-1}$, nos anos de 1988, 1990 e 1991, respectivamente, em função dos níveis de tensão de água no solo. O melhor ajuste encontrado foi o logarítmico, sendo mostrado o comportamento para os três anos na Figura 15.

$\hat{Y}=4014,5-278,6 \ln \psi, \quad \mathrm{R}^{2}=83,87 \%$

$\hat{Y}=3975,4-286,85 \ln \psi, \mathrm{R}^{2}=85,76 \%$

$\hat{Y}=4129,6-240,75 \ln \psi, \mathrm{R}^{2}=85,36 \%$

em que:

$\hat{Y}$ - rendimento da cultura em $\mathrm{kg} \cdot \mathrm{ha}^{-1}$.

$\psi$ - tensão da água no solo, em $\mathrm{kPa}$, tal que,

$36 \mathrm{kPa} \leq \psi \geq 917 \mathrm{kPa}$, em $1988 ;$

$38 \mathrm{kPa} \leq \psi \geq 994 \mathrm{kPa}$, em $1990 \mathrm{e}$

$37 \mathrm{kPa} \leq \psi \geq 990 \mathrm{kPa}$, em 1991 . 


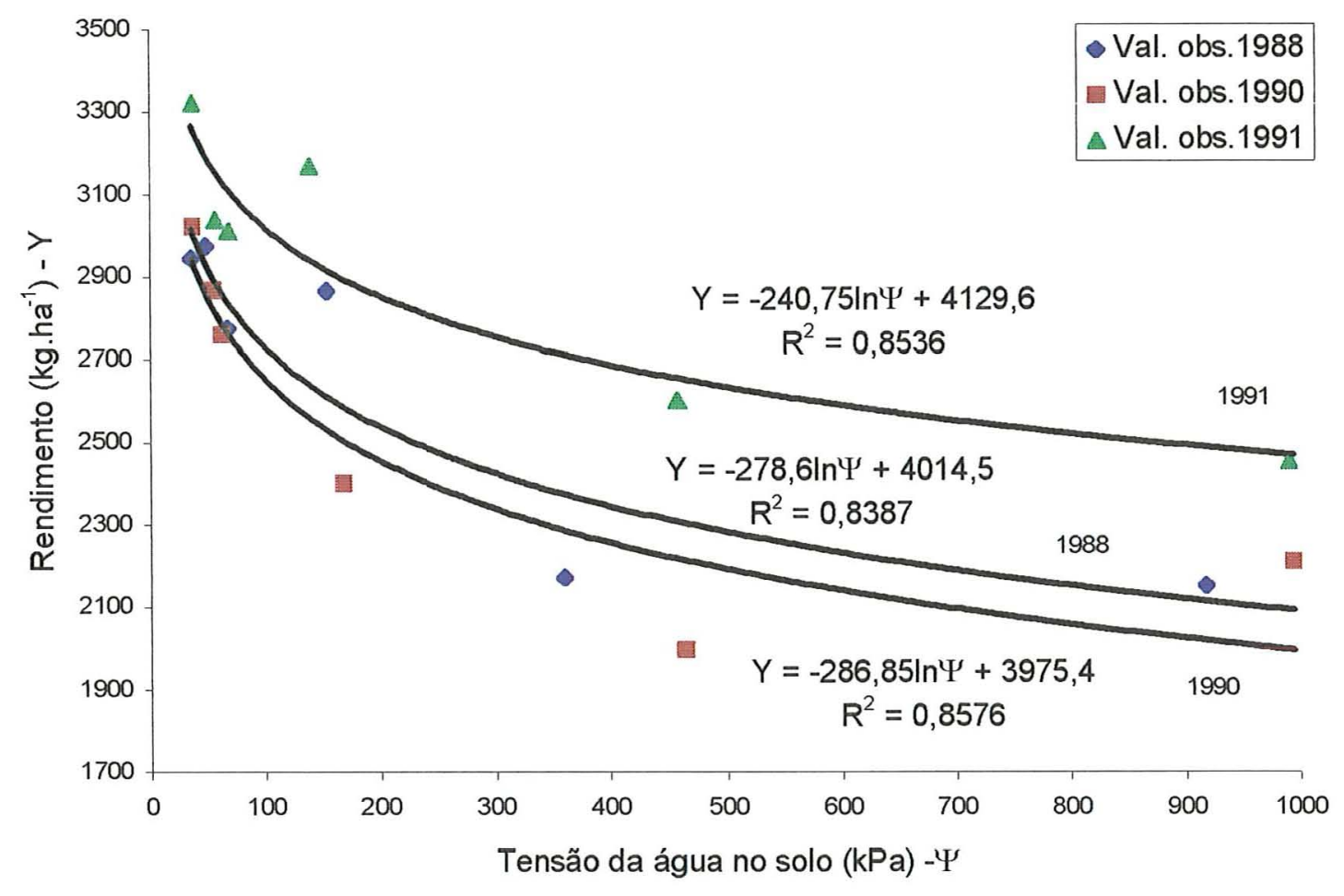

Figura 15 - Rendimento de grãos em kg.ha ${ }^{-1}$ em função da tensão da água no solo.

Com relação as maiores produtividades obtidas no ano de 1991 (Figura 15), podem ser atribuídas às boas condições sanitárias da cultura. O que não ocorreu para os anos de 1988 e 1990, onde foram verificados um leve ataque de oídio. Um outro fator que pode ter colaborado, é o efeito residual cumulativo da adubação ao longo dos três anos.

\subsubsection{Eficiência de uso da água}

Observa-se na Tabela 19, que houve diferença significativa entre os tratamentos para eficiência do uso da água aplicada nos três anos estudados, resultado esperado, já que essa variável é dependente da variável rendimento, em $\mathrm{kg} \cdot \mathrm{ha}^{-1}$, que apresentou diferença significativa, entre os tratamentos, conforme foi observado no ítem anterior. As médias obtidas encontram-se na Tabela 20. 
Tabela 19 - Análise da variância e teste $\mathrm{F}$ para tratamentos (tensão da água no solo), para a variável eficiência de uso de água, nos anos de 1988, 1990 e 1991.

\begin{tabular}{lclll}
\hline Causas da variação & G.L. & \multicolumn{3}{c}{ QUADRADOS MÉDIOS } \\
\cline { 3 - 5 } & & \multicolumn{1}{c}{1988} & \multicolumn{1}{c}{1990} & 1991 \\
\hline Blocos & 3 & 0,4399 & 0,0916 & 0,3204 \\
Tratamentos & 5 & $2,3172^{* *}$ & $3,1463^{* *}$ & $6,3175^{* *}$ \\
Resíduo & 15 & 0,3296 & 0,2772 & 0,3768 \\
Total & 23 & & & \\
\hline
\end{tabular}

** = Significativo, pelo teste $F$, ao nivel de $1 \%$

ns $=$ Não significativo, pelo teste $F$, considerando-se um n.m.s. de $5 \%$.

Tabela 20 - Eficiência de uso da água $\left(\mathrm{kg} \cdot \mathrm{mm}^{-1}\right)$ em função da tensão da água no solo nos anos de 1988, 1990 e 1991.

\begin{tabular}{ccccccc}
\hline Tratamentos & \multicolumn{2}{c}{1988} & \multicolumn{2}{c}{1990} & \multicolumn{2}{c}{1991} \\
\cline { 2 - 7 } & Tensão & Média & Tensão & Média & Tensão & Média \\
\hline T1 & 36 & 4,73 & 38 & 5,72 & 37 & 5,51 \\
T2 & 49 & 5,21 & 56 & 5,15 & 57 & 5,23 \\
T3 & 68 & 4,95 & 63 & 6,02 & 69 & 6,35 \\
T4 & 154 & 6,15 & 169 & 6,26 & 140 & 6,75 \\
T5 & 361 & 6,01 & 464 & 5,99 & 458 & 7,39 \\
T6 & 917 & 6,64 & 994 & 6,80 & 990 & 7,32 \\
\hline
\end{tabular}

As equações 15, 16 e 17 foram ajustadas para eficiência de uso da água respectivamente para os anos de 1988, 1990 e 1991, em função da tensão da água no solo. Nos três anos o melhor ajuste foi o logarítmico, cujo comportamento é mostrado na Figura 16.

$$
\begin{aligned}
& \hat{Y}=2,8453+0,5644 \ln \psi, \quad \mathrm{R}^{2}=87,32 \% \\
& \hat{Y}=4,3765+0,3229 \ln \psi, \quad \mathrm{R}^{2}=58,58 \% \\
& \hat{Y}=3,2854+0,631 \ln \psi, \quad \mathrm{R}^{2}=80,45 \%
\end{aligned}
$$


em que:

$\hat{Y}$ - eficiência de uso da água em kg. $\mathrm{mm}^{-1}$.

$\psi$ - tensão da água no solo, em $\mathrm{kPa}$, tal que,

$$
\begin{aligned}
& 36 \mathrm{kPa} \leq \psi \geq 917 \mathrm{kPa}, \text { em } 1988 ; \\
& 38 \mathrm{kPa} \leq \psi \geq 994 \mathrm{kPa}, \text { em } 1990 \mathrm{e} \\
& 37 \mathrm{kPa} \leq \psi \geq 990 \mathrm{kPa}, \text { em } 1991 .
\end{aligned}
$$

Os maiores valores para a eficiência de uso da água no ano de 1991 (Figura 16), são devido as maiores produtividades obtidas nesse ano, já que essas são utilizados para o cálculo da eficiência de uso da água.

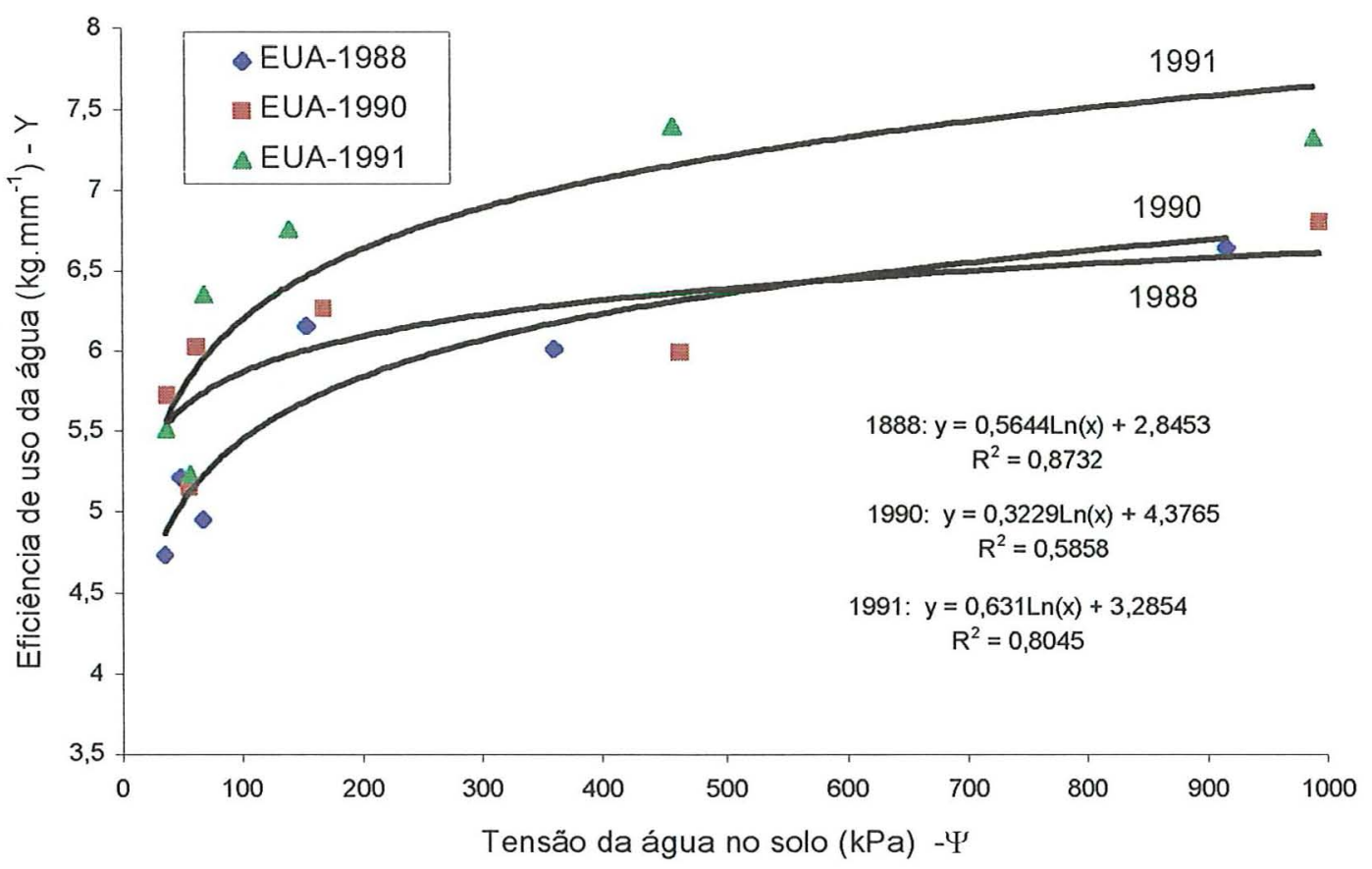

Figura 16 - Eficiência de uso da água em função da tensão da água no solo.

Quanto ao menor valor de $\mathrm{R}^{2}$ para no ano de 1990, provavelmente está associado, à ocorrência de chuvas durante o período experimental (Tabela 3). Outrossim, as lâminas 
totais foram menores para esta ano, também devido ao período chuvoso, que promoveu redução das necessidades de evaporação (Tabela 3) e transpiração das plantas, nesse ano.

Observa-se na Figura 16, que as curvas ajustadas para a variável eficiência de uso da água tiveram um comportamento oposto ao das curvas ajustadas para a variável rendimento de grãos, o que se esperava ocorrer por já ter sido encontrado por vários autores, entre os quais Saad e Libardi (1994) constataram que a eficiência de uso da água foi maior onde ocorreu maior déficit hídrico.

\subsubsection{Número de irrigações aplicadas}

O estudo da relação entre tensão de água no solo e número de irrigação mostrou comportamento logarítmico para os três anos, sendo ajustadas as equações 18,19 e 20, respectivamente para os anos de 1988, 1990 e 1991. A Figura 17 ilustra esse comportamento.

$\hat{Y}=34,048-4,5611 \ln \psi, \quad \mathrm{R}^{2}=89,64 \%$

$\hat{Y}=44,653-6,135 \ln \psi, \mathrm{R}^{2}=75,22 \%$

$\hat{Y}=45,384-5,9317 \ln \psi, \mathrm{R}^{2}=91,63 \%$

em que:

$\hat{Y}$ - número de irrigações aplicadas.

$\psi$ - tensão da água no solo, em $\mathrm{kPa}$, tal que,

$$
\begin{aligned}
& 36 \mathrm{kPa} \leq \psi \geq 917 \mathrm{kPa}, \text { em } 1988 ; \\
& 38 \mathrm{kPa} \leq \psi \geq 994 \mathrm{kPa}, \text { em } 1990 \mathrm{e} \\
& 37 \mathrm{kPa} \leq \psi \geq 990 \mathrm{kPa}, \text { em } 1991 .
\end{aligned}
$$

Em relação à água aplicada para os três anos do experimento conforme Tabela 8 e Figura 17, observa-se que nos tratamentos de 36,38 e $37 \mathrm{kPa}$ foram necessários 20, 28 e 26 irrigações, num total de 623,528 e $602 \mathrm{~mm}$, respectivamente, para os anos de 1988, 1990 e 1991. 

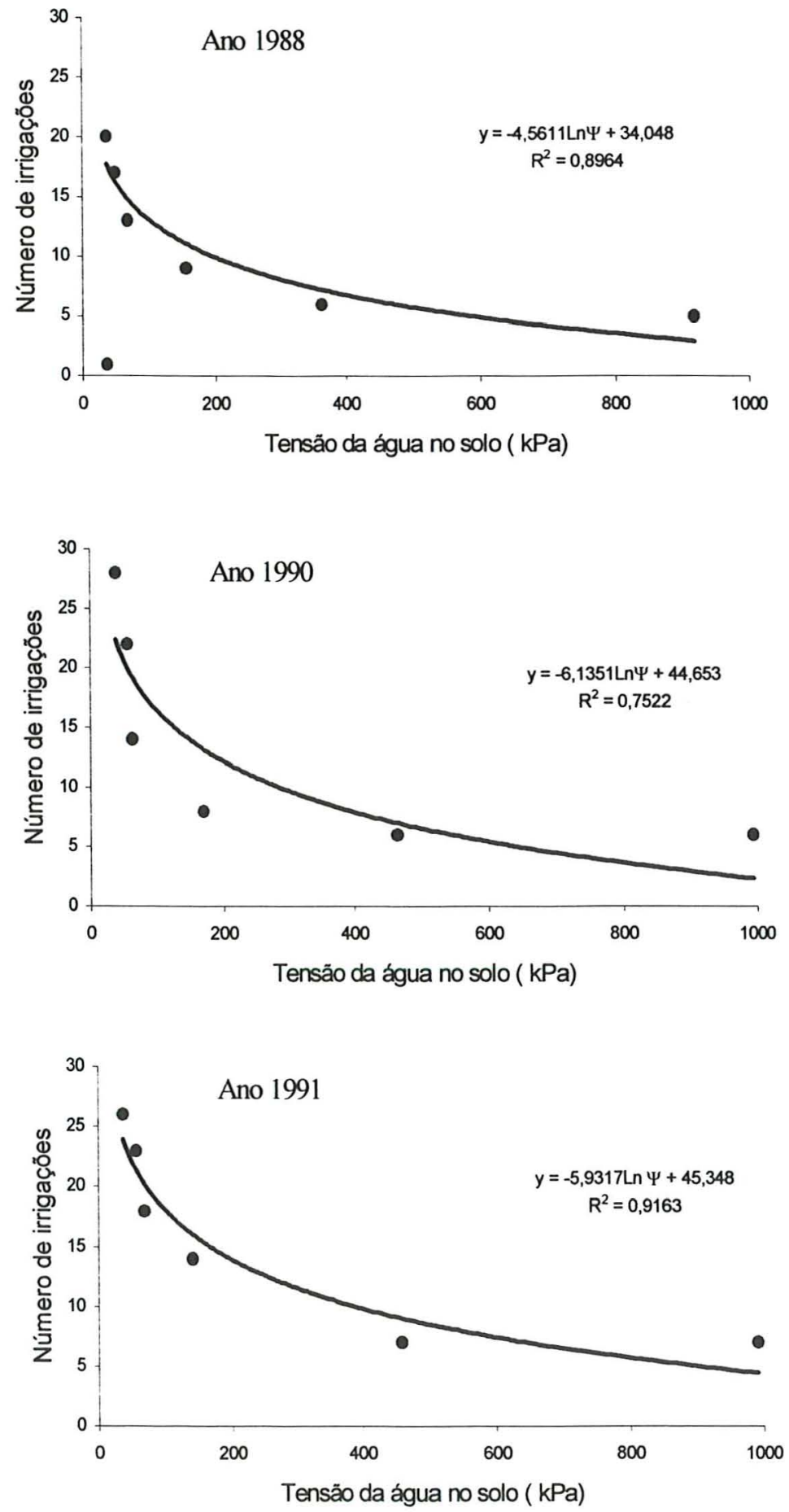

Figura 17- Número total de irrigações em função da tensão da água no solo para os anos de 1988, 1990 e 1991. 
As diferenças entre o número de irrigações entre os três anos podem ser atribuidos às variações edafoclimáticas entre os anos. Para o ano de 1990 o maior número de irrigações possivelmente ocorreu devido as precipitações pluviométricas terem proporcionado armazenamento de água na camada considerada para o cálculo da irrigação $(0-40 \mathrm{~cm})$. Porém o controle da irrigação foi feito na profundidade de $10 \mathrm{~cm}$, portanto muito sensível às variações climáticas e pouco sensível à água armazenada nas camadas abaixo. Em conseqüência, as irrrigações se tornaram mais freqüentes, porém com menores lâminas, o que pode ser observado na Tabela 7. No Anexo I (Tabela 22) pode ser observado que, após o período de ocorrência das precipitações pluviométricas (06 à 14/07/1990), o intervalo entre irrigações foi menor e as lâminas não aumentaram, como seria o esperado, com desenvolvimento fenológico das plantas.

\subsubsection{Lâmina total de água}

A lâmina total de água variou em função dos níveis de tensão da água no solo, seguindo comportamento logarítmico. Foram ajustadas as equações 21,22 e 23 respectivamente para os anos de 1988, 1990 e 1991, cujo comportamento é apresentado na Figura 18.

$$
\begin{aligned}
& \hat{Y}=953,06-95,522 \ln \psi, \quad \mathrm{R}^{2}=97,58 \% \\
& \hat{Y}=782,33-70,418 \ln \psi, \quad \mathrm{R}^{2}=85,91 \% \\
& \hat{Y}=887,49-82,13 \ln \psi, \quad \mathrm{R}^{2}=90,47 \%
\end{aligned}
$$

em que:

$\hat{Y}$ - lâmina total de água em $\mathrm{mm}$.

$\psi$ - tensão da água no solo, em $\mathrm{kPa}$, tal que,

$36 \mathrm{kPa} \leq \psi \geq 917 \mathrm{kPa}$, em 1988 ;

$38 \mathrm{kPa} \leq \psi \geq 994 \mathrm{kPa}$, em $1990 \mathrm{e}$

$37 \mathrm{kPa} \leq \psi \geq 990 \mathrm{kPa}$, em 1991.

A lâmina total de água em função da tensão da água no solo variou de forma que com o aumento desta houve necessidades de aplicações de menores lâminas. Para os três 

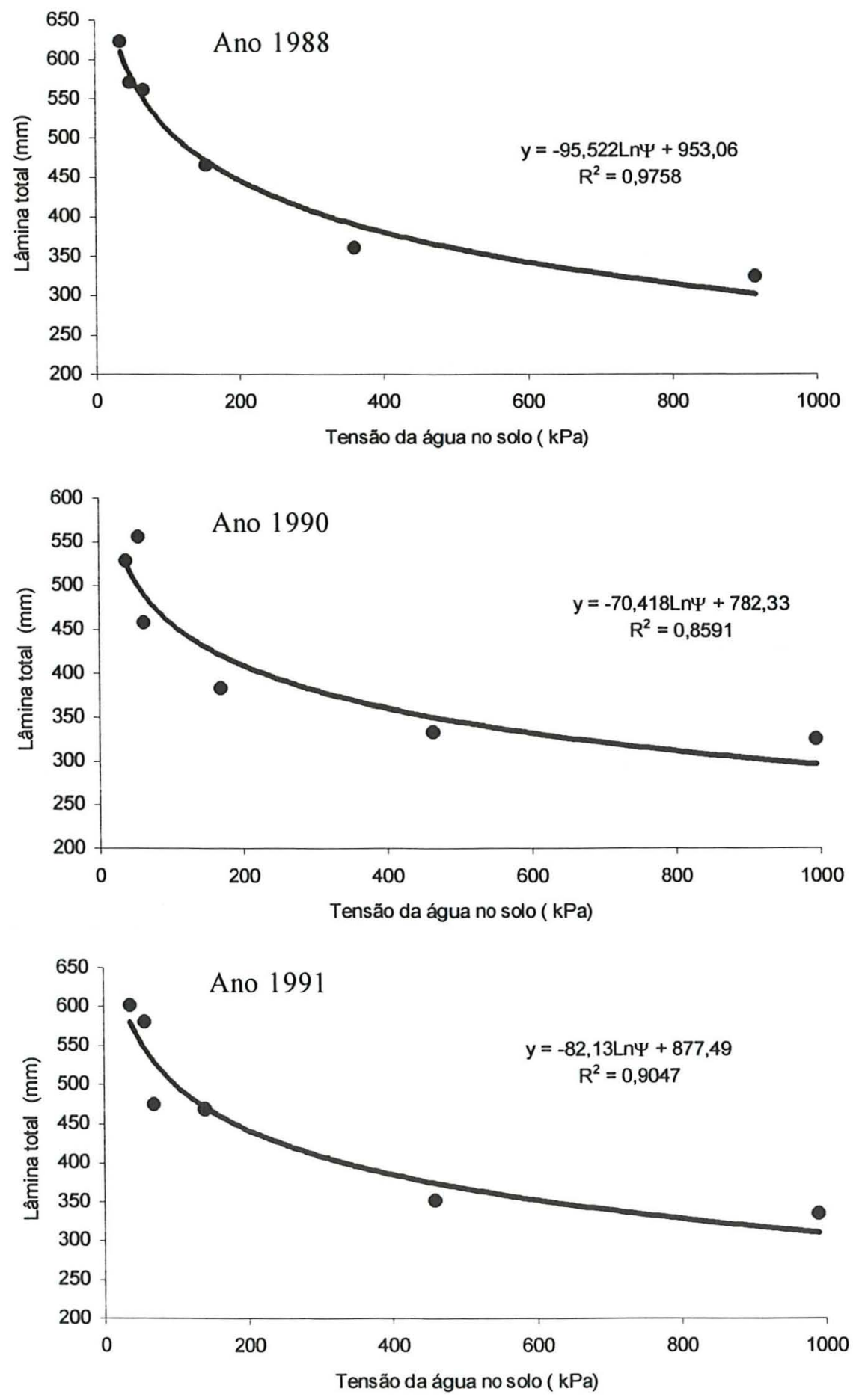

Figura 18- Lâmina total de água (irrigação e precipitação) em função da tensão da água no solo para os anos de 1988, 1990 e 1991. 
anos estudados, apresentou comportamento semelhante, porém no ano de 1990, as lâminas totais foram menores, devido a ocorrência de precipitação pluvial, num total de $67,7 \mathrm{~mm}$. Isto pode também ser confirmado observando-se a Tabela 3, onde no ano de 1990 , os valores do tanque classe A ( $\mathrm{mm}$ ) foram menores no período de maior consumo de água pela cultura. A ocorrência de chuvas provavelmente foi responsável para que no ano de 1990, o coeficiente de determinação $\mathrm{R}^{2}$ fosse menor em relação aos anos de 1988 e 1991.

Fazendo-se a regressão conjunta para três anos ajustou-se a Equação 24, cujo comportamento é mostrado na Figura 19.

$=872,12-82,848 \ln \psi, \quad \mathrm{R}^{2}=87,44 \%$

em que:

$\hat{Y}$ - lâmina total de água em mm.

$\psi$ - tensão da água no solo, em $\mathrm{kPa}$, tal que, $36 \mathrm{kPa} \leq \psi \geq 994 \mathrm{kPa}$.

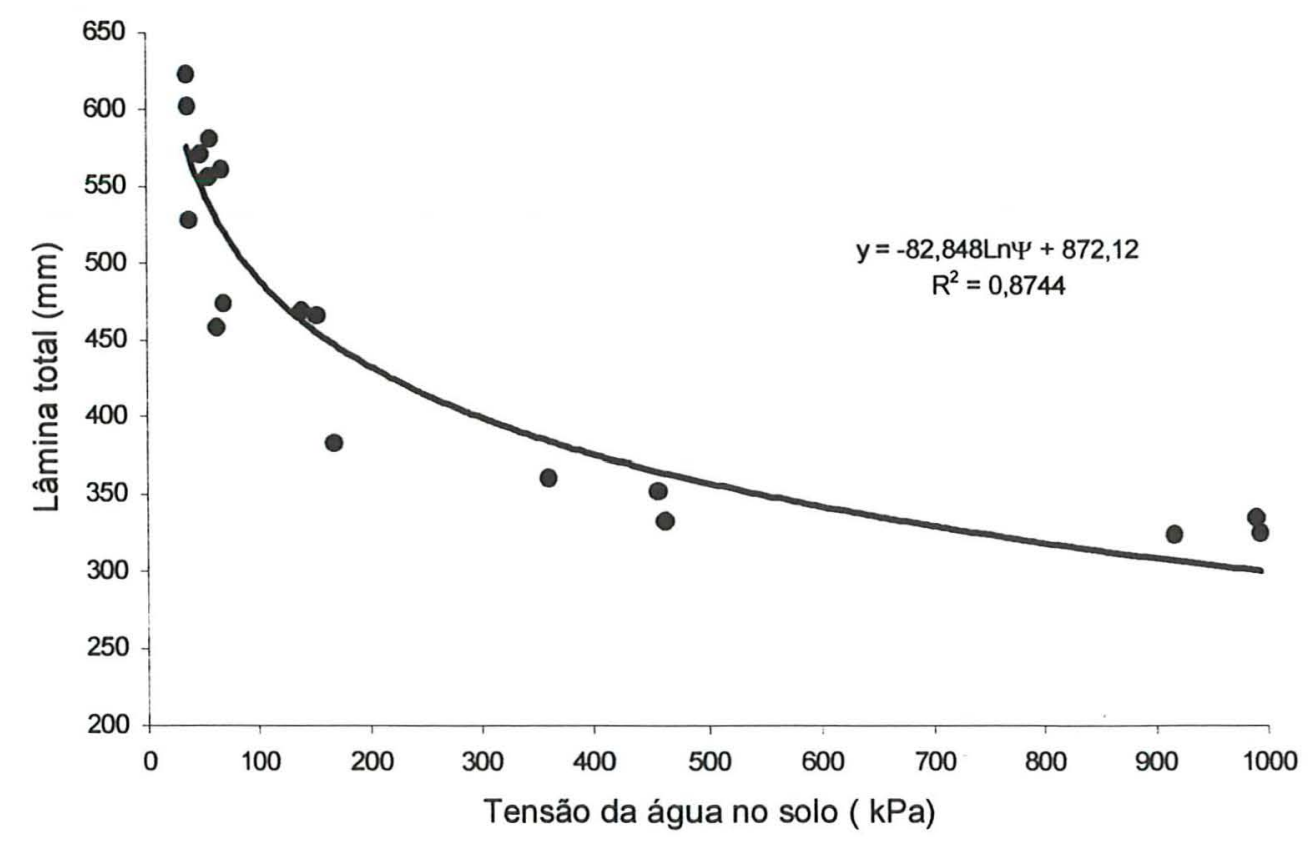

Figura 19- Lâminas totais em função da tensão da água no solo conjunta para os anos de 1988,1990 e 1991. 


\subsubsection{Rendimento de grãos em função das lâminas totais}

As funções de resposta da cultura do feijoeiro em função da lâmina total são importantes para serem usadas em decisões de caráter econômico referentes ao nível de manejo em que as irrigações devam ser feitas. Deste modo foram ajustadas as equações 25,26 e 27 respectivamente para os anos de 1988, 1990 e 1991, que tiveram um comportamento quadrático, sendo o comportamento apresentado na Figura 20.

$\hat{Y}=-1231,8+14,096 \mathrm{x}-0,0119 \mathrm{x}^{2}, \mathrm{R}^{2}=91,78 \%$, com ponto máximo de 592,3

$\hat{Y}=-1761,4+16,471 \mathrm{x}-0,0144 \mathrm{x}^{2}, \mathrm{R}^{2}=93,33 \%$, com ponto máximo de 571,9

$\hat{Y}=-949,78+14,459 \mathrm{x}-0,0126 \mathrm{x}^{2}, \mathrm{R}^{2}=89,45 \%$, com ponto máximo de 573,8

em que:

$\hat{Y}$ - Rendimento de grãos em kg.ha ${ }^{-1}$.

$\psi$ - laminas totais (LAM) em mm, em $\mathrm{kPa}$, tal que

$324 \mathrm{~mm} \leq \mathrm{LAM} \geq 623 \mathrm{~mm}$, em 1990;

$325 \mathrm{~mm} \leq \mathrm{LAM} \geq 556 \mathrm{~mm}$, em $1990 \mathrm{e}$

$335 \mathrm{~mm} \leq \mathrm{LAM} \geq 602 \mathrm{~mm}$, em 1991.

O comportamento quadrático era esperado por ser característico dessas variáveis. Diversos autores encontraram resultados semelhantes para várias culturas, como exemplo para o feijoeiro citam-se Frizzone (1990) e Stone \& Moreira (1995). Os pontos críticos máximos encontrados de 592,$3 ; 571,9$ e 573,8 , em mm, respectivamente para os três anos, apresentaram magnitude semelhante. Porém no ano de 1990 o ponto máximo ficou situado acima do intervalo de validade da respectiva equação, indicando a necessidade de tratamentos com tensões inferiores à $38 \mathrm{kPa}$, que foi a menor tensão média observada (T1) para o ano. Isso conseqüentemente proporcionaria maiores lâminas totais, o que seria necessário para uma verificação adequada do ponto de máximo, para esse ano.

Com os valores dos pontos críticos máximos das lâminas, podem ser calculadas a tensão da água no solo correspondente, fazendo-se uso das equações 21,22 e 23 , de maneira inversa, tendo como entrada os respectivos pontos de máximos para cada ano. 

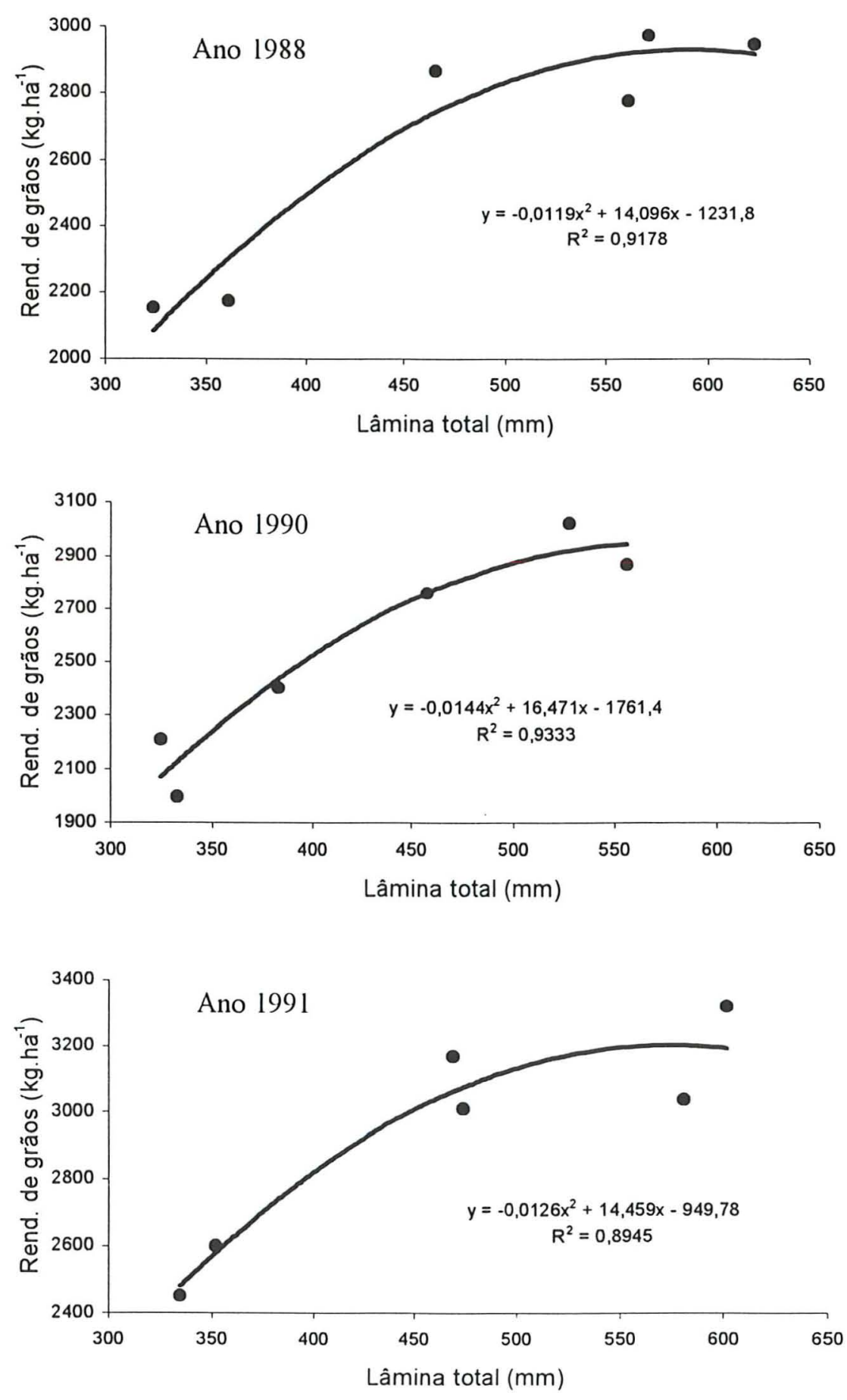

Figura 20 - Rendimento de grãos em função da lâmina total de água (irrigação e precipitação) para os anos de 1988, 1990 e 1991. 
Dessa forma obteve-se os valores da tensão da água no solo correspondentes a máxima produtividade de 43,7; 19,8 e 40,4 $\mathrm{kPa}$, para os três anos, respectivamente. Todavia, no ano de 1990 o ponto máximo encontrado de 19,8 kPa está fora do intervalo dos dados que geraram a equação, portanto, o mesmo não tem validade para determinação do momento de irrigar.

Fazendo-se uma regresssão conjunta para os anos de 1988, 1990 e 1991, ajustouse a Equação 28, cujo comportamento é mostrado na Figura 21.

$\hat{Y}=-1557,9+16,032 \mathrm{x}-0,014 \mathrm{x}^{2}, \mathrm{R}^{2}=79,80 \%$, com ponto máximo de 572,57

em que:

$\hat{Y}$ - Rendimento de grãos em kg.ha ${ }^{-1}$.

$\psi$ - laminas totais (LAM) em mm, em $\mathrm{kPa}$, tal que, $324 \mathrm{~mm} \leq \mathrm{LAM} \geq 623 \mathrm{~mm}$.

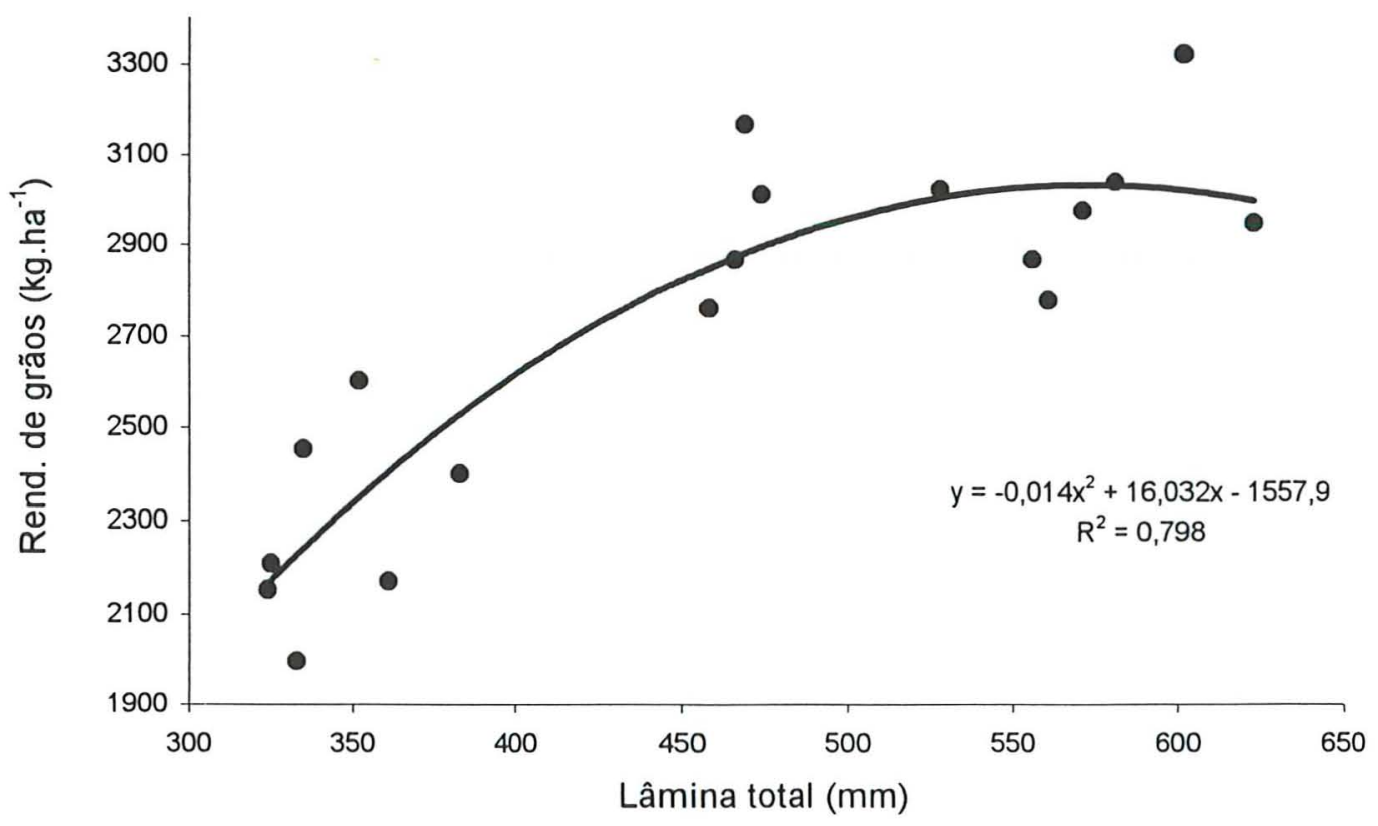

Figura 21 - Curva de rendimento conjunta para os anos de 1988, 1990 e 1991. 
O ponto de máximo observado foi de 572,57 , que é um valor semelhante ao encontrado por Frizzone (1986) onde o máximo rendimento de grãos foi encontrado para a lâmina de água de $570,4 \mathrm{~mm}$ com adubação nitrogenada de $117,4 \mathrm{~kg} \cdot \mathrm{ha}^{-1}$. Para o cálculo da tensão correspondente, pode-se fazer uso da Equação 24, de maneira inversa, tendo como entrada a lâmina de $572,57 \mathrm{~mm}$, obtendo-se o valor de $37,18 \mathrm{kPa}$, podendose considerar este valor como adequado para obtenção de produtividades máximas. Deve-se ressaltar que este valor foi obtido com leituras feitas a $10 \mathrm{~cm}$ de profundidade, na linha das plantas.

Apesar dos resultados indicarem que as irrigações devam ser feitas quando as tensões de água no solo atingirem em torno $37 \mathrm{kPa}$, para maiores produtividades, o uso desta recomendação pelos produtores irá depender dos custos da irrigação e do preço do feijão, que são variáveis ao longo do tempo. Portanto, a decisão deve ser complementada com os resultados da análise econômica. 


\section{CONCLUSÕES}

Diante das condições e resultados obtidos para a cultura do feijoeiro, pode-se concluir que:

- Para a obtenção de maiores produtividades, as irrigações devem ser feitas quando as leituras dos tensiômetros instalados na linha de plantio à $10 \mathrm{~cm}$ de profundidade estiverem em torno de $37 \mathrm{kPa}$.

- A produtividade de grãos reduziu-se continuamente em função do aumento da tensão da água no solo no intervalo entre $37 \mathrm{kPa}$ a $967 \mathrm{kPa}$, seguindo um comportamento logarítmico. Resultados semelhantes foram encontrados para a altura de plantas, número de vagens por planta e número de grãos por vagem. 


\section{REFERÊNCIAS BIBLIOGRÁFICAS}

ALMEIDA, V.M. de; RAMALHO, M.A.P.; REIS, A.J. DOS; MUNIZ, J.A. Avaliação agronômica e econômica de sistemas de produção de feijão irrigado (Phaseolus vulgaris L.). Ciência e Prática, v. 14, n.2. p.125-136, 1990.

ALVES, M.I.F. Introdução à análise exploratória de dados. Piracicaba: ESALQ, DME, 1987. 40p.

ARRUDA, F.B. Uso da água na produção agrícola. In: SIMPÓSIO SOBRE O MANEJO DE ÁGUA NA AGRICULTURA, Campinas, 1987. Fundação Cargill, 1987. p. 177-189.

AZEVEDO, J.A. de.; CAIXETA, T.J. Irrigação do feijoeiro. Planaltina: EMBRAPA, CPAC, 1986. 60p. (EMBRAPA, CPAC. Circular Técnica, 20).

AZEVEDO, J.A. de.; SILVA, E.M. da. Características fisico-hídricas importantes para a irrigação de solos representativos de cerrados. In: CONGRESSO BRASILEIRO DE ENGENHARIA AGRÍCOLA, 11., Brasilia, 1981. Anais. Brasilia: SBEA, 1983. p.843-844.

AZEVEDO. J.A. de; SILVA, E.M. da; RESENDE, M. ; GUERRA, A.F. Aspectos sobre manejo da irrigação por aspersão para o cerrado. Planaltina: EMBRAPA, CPAC, 1983. 53p. (EMBRAPA, CPAC. Circular Técnica, 16). 
BARROS, L.C.G.; HANKS, R.J. Evapotranspiration and yield of beans as affected by mulch and irrigation. Agronomy Journal, v.85, p.692-697, 1993.

BASCUR, B.G.; FRITSCH, F. N. Efectos de métodos y frequencias de riego sobre componentes de rendimiento en frijol (Phaseolus vulgaris L.). Agricultura Técnica, v.35, n.3, p. 145-152, 1975.

BERNARDO, S.; GALVÃO, J. D.; GUERINI, H; CARVALHO, J.B. de. Efeito de níveis de tensão de água no solo sobre a produção do feijoeiro (Phaseolus vulgaris L.). Seiva, v. 30, n. 71, p. $7-13,1970$.

BHAN, S. It pays to irrigate wheat the scientific way. Indian Farming, v.27, n.3, p.13-18, 1977.

BOUYOUCOS, G.J. Soil moisture measurement improved. Agricultural Engineering, v. 42, n. 3, p. $136-138,1961$.

CAIXETA, T.J. Irrigação do feijoeiro. Informe Agropecuário, v.4, n.6, p.36-40, 1978.

CANNEL, G.H.; ASBELL, C.W. Prefabrication of mold and construction of cylindrical eletrode-type resistence units. Soil Science, v.97, n.2, p.108-112, 1964.

CHOUDHURY, P.N.; KUMAR, V. The sensitivity of growth and yield of dwarf wheat to water stress at three growth stages. Irrigation Science, v.1, n.4, p.223-231, 1980. 
CORDEIRO, J.C. Características fisico-hídricas de latossolos sob vegetação de cerrados do Brasil/Central. Rio de Janeiro, 1977. 122p. Dissertação (Mestrado) Universidade Federal Rural do Rio de Janeiro.

COSTA, A.C.S. da. Balanço hidrico em culturas de feijão (Phaseolus vulgaris L.) sob condições de campo. Piracicaba, 1986. 166p. Dissertação (Mestrado) Escola Superior de Agricultura "Luiz de Queiroz", Universidade de São Paulo.

COSTA, R.C.L. Efeito de níveis de água e de doses de nitrogênio sobre o crescimento, morfologia, partição de assimilados e troca de CO em Phaseolus vulgaris L. Viçosa, 1986. 90 p. Dissertação (M.S.) - Universidade Federal de Viçosa.

COSTA, R.C.L.; LOPES, N.F.; OLIVA, M. A. Crescimento, morfologia, partição de assimilados e produção de matéria seca em Phaseolus vulgaris L. submetidos a três níveis de nitrogênio e dois regimes hídricos. Pesquisa Agropecuária Brasileira, v.26, n.9, p. 1453-1465, 1991.

COUTO, L. Effects of water stress on growth, reproductive development, dry matter partitioning, and yeld components of beans (Phaseolus vulgaris L.) in the field. Dissertation Abstracts International. B Sciences Engineering, Ann Arbor, v.394, p. $56-95,1979$

CURL, E.A. Control of plant deseases by plant rotation. Botanical Review, v.29. n.4, p.413-477, 1963.

DOORENBOS, J. ; KASSAN, A.H. Crop response to water. Rome: FAO, 1979 194p. (FAO. Irrigation and Drainage Paper, 33). 
DOORENBOS, J.; PRUITT, W.O. Guidelines for predicting crop water requirement. Rome: FAO, 1975. 179p. (FAO Irrigation and Drainage Paper, 24).

EMPRESA BRASILEIRA DE PESQUISA AGROPECUÁRIA. Centro Nacional de Pesquisa da Arroz e Feijão. Informações técnicas para o cultivo do feijão irrigado (GO, DF, MG, ES, SP, RJ) . Goiània, 1989. 35p. (EMBRAPA - CNPAF-Circular Técnica, 23).

FANCELLI, A.L.; DOURADO NETO, D. (Ed.) Tecnologia da produção do feijão irrigado. Piracicaba: ESALQ, Departamento de Agricultura, 1987. p.121-133: Recomendações gerais na operacionalização e manutenção de sistemas de irrigação.

FANCELLI, A.L.; DOURADO NETO, D. Tecnologia da produção do feijão irrigado. Piracicaba: ESALQ, Departamento de Agricultura, 1997.65p.

FAVARO, J.C.; PILATTI, R.A. Efecto de la temperatura y el deficit hídrico sobre el crecimiento de los frutos de frijol (Phaseolus vulgaris L.). Turrialba, v.38, n.3, p. $168-172,1988$

FNP CONSULTORIA. Agrianual-96. São Paulo, 1996. p.249.

FOLEGATTI, M.V. Avaliação do desempenho de um "scheduler" na detecção do estresse hidrico em cultura do feijoeiro (Phaseolus vulgaris L.) irrrigada com diferentes lâminas. Piracicaba, 1988. 133p. Tese (Doutorado) - Escola Superior de Agricultura "Luiz de Queiroz", Universidade de São Paulo. 
FORSYTHE, W.M.; LEGARDA, L.B. Soil water and aeration and red bean production. I. Mean maximum soil moisture suction. Turrialba, v.28, n.1, p.81-86, ene/mar. 1978.

FRIZZONE, J.A. Funções de resposta do feijoeiro (Phaseolus vulgaris L.) ao uso de nitrogênio e lâmina de irrigação. Piracicaba, 1986. 133p. Tese (Doutorado)- Escola Superior de Agricultura "Luiz de Queiroz", Universidade de São Paulo.

FRIZZONE, J.A; OLLITA, A.F.L.; PEREIRA, G.T. Funções de resposta do feijoeiro (Phaseolus vulgaris L.) ao uso do nitrogênio e lâmina de irrigação. I. Região de produção racional. ITEM. Irrigação e Tecnologia Moderna, n.28, p.26-32, 1987.

GARDNER, W.H. Water content. In: BLACK, C.A. Methods of soil analysis. Madison: American Society of Agronomy, 1965. pt.1, cap.7, p.82-127.

GORNAT, B.; SILVA, W.L.C. Sistema de controle e automatização da irrigação. ITEM. Irrigação e Tecnologia Moderna, v.43, p.37-39, 1990.

GUERRA, A.F.; SILVA, E.M. da; AZEVEDO, J.A. de. Estabelecimento do momento de irrigação em trigo e cevada baseado em níveis de tensão de água em latossolo dos Cerrados. In: EMPRESA BRASILEIRA DE PESQUISA AGROPECUÁRIA. Centro de Pesquisa Agropecuária dos Cerrados. Relatório técnico anual. 19821985. Planaltina, 1987. p.227-231.

GUERRA, A. F.; SILVA, E.M. da.; AZEVEDO, J.A. de. Tensão de água no solo: um critério viável para a irrigação do trigo na região dos cerrados. Pesquisa Agropecuária Brasileira, v.29, n.4, p.631-636, 1994. 
HAISE, H.R. ; HAGAN, R. M. Soil, plant, and evaporative measurements a criteria for scheduling irrigation. In: HAGAN, R. M. ; ADMINISTER, T.W. (Ed.) Irrigation of agricultural lands. Madison: America Society of Agronomy, 1967. p.577-604.

HEERMANN, D.F.; MARTIN, D.L.; JACKSON, R.D.; STEGMAN, E.C. Irrigation scheduling controls and techniques. In: STEWART, B.A. ; NIELSEN, D.R. (Ed.) Irrigation of agricultural crops. Madison. ASAE, 1990. p.509-535 (ASAE. Agronomy Séries, 30).

HEGDE, D.M.; SRINIVAS, K. Effect of irrigation and nitrogen on growth, yield and water use frenchbean. Indian Journal of Agronomy, v.34, n.2, p.180-184, 1989.

HILLEL, D. Fundamental soil physics. Academic Press, London. 1980. p.70-72.

HOAGLIN, D.C.; MOSTELLER, F.; TUKEY, J.W. Análise exploratória de dados. Técnicas robustas. Lisboa: Edições Salamandra. 1992. 446p. (Série Novas Tecnologias).

HOSTALÁCIO, S.; VÁLIO, I.F.M. Desenvolvimento de plantas de feijão cv. Goiano Precoce, em diferentes regimes de irrigação. Pesquisa Agropecuária Brasileira, v.19, p.211-218, 1984.

LUCHIARI JÚNIOR, A. Determinação do coeficiente de cultura $(\mathrm{kc})$ para feijão (Phaseolus vulgaris L.) pelo método do balanço hídrico. Piracicaba, 1978. 59p. Dissertação (Mestado) - Escola Superior de Agricultura "Luiz de Queiroz", Universidade de São Paulo. 
MACK, H.J.; VARSVELD, G.H. Response of bush snap beans (Phaseolus vulgaris L.) to irrigation and plant density. Journal of the American Society for Horticultural Science, v.107, n.2, p.286-290, 1982.

MAGALHÃES, A.A.; MILLAR, A.A. Efeito do déficit de água no período reprodutivo sobre a produção de feijão. Pesquisa Agropecuária Brasileira, v. 13, n.2, p. 55-60, 1978.

MAGALHÃES, A.A.; MILlAR, A.A.; CHOUDHURY, E.N. Efeito do déficit fenológico de água sobre a produção de feijão. Turrialba, v.29, n.4, p.262-73, 1979.

MAROUELLI, W.A.; GIORDANO, L.B.; OLIVEIRA, C.A.S.; CARRIJO, O.A. Desenvolvimento, produção e qualidade de ervilha sobre diferentes tensões de água no solo. Pesquisa Agropecuária Brasileira, v.26, n.7, p.1041-1047, 1991.

MIRANDA, O.; BELMAR, C. Déficit hídrico y frequencia de riego en frijol (Phaseolus vulgaris L.). Agricultura Técnica, v.494, p.271-278, 1977.

MISHRA, R.D.; SHARMA, K.C.; WRIGHT, B.C.; SINGH, V.P. Critical stages in irrigation requirements of wheat variety Lermarojo. Indian Journal for Agricultural Science, v.39, p.898-904, 1969.

MYIAZAWA, K.; FIGUERÊDO, S.F.; PERES, J.R.; ANDRADE, L.M. Estabelecimento do momento de irrigação em feijão e ervilha baseado em niveis de tensão de água em Latossolo Vermelho Escuro dos Cerrados. In: EMPRESA BRASILEIRA DE PESQUISA AGROPECUÁRIA. Centro de Pesquisa Agropecuária dos Cerrrados. Relatório Técnico do Projeto Nipo-Brasileiro de Cooperação em Pesquisa Agrícola nos Cerrados 1987/1992. Brasília, 1994. p.368-402 
OLIVEIRA, F.A. de; SILVA, J.J.S. Evapotranspiração, índice de área foliar e desenvolvimento radicular do feijão irrigado. Pesquisa Agropecuária Brasileira, v. 25, n. 3, p. $317-322,1990$.

PARJOL, L. Investigation of drought resistence in beans at different growth stages. Field Crops Abstracts, Wallingford, 1976, v.29, n.11, p.776. (Abstract 8774).

PERES, J.R.R.; SUHET, A.R.; VARGAS, M.A.T. Fixação de nitrogênio atmosférico pela ervilha em solo de cerrados. Ervilha: integraçõao pesquisa iniciativa privada. Informe Agropecuário, v. 14, n. 158, p. 16-19, 1989.

PHENE, C.J.; ALLEE, C.P.; PIERRO, J.D. Soil matric potential sensor measurements in real-time irrigation scheduling. Agricultural Water and Management, v.16, n.3, p.173-185, 1989.

PINTER JUNIOR, P.J.; ZIPOLI, G.; REGINATO, R.J.; JACKSON, R.J.; IDSO, S.B.; HOFMAN, J.P. Canopy temperaure as an indicator of differential water use and yield performance among wheat cultivars. Agricultural Water and Management, v. 18, n. 1, p. $35-48,1990$.

PORTES, T. de A. Manual de métodos de pesquisa em feijão: parâmetros fisiológicos e agronômicos empregados na pesquisa com feijão (Phaseolus vulgaris L.) Suplemento I. Goiânia :EMBRAPA, CNPAF, 1981. 22p.

POZZEBON, E.J. Resposta da cultura do feijão à irrigação, fertirrigação e uso de micronutrientes. Santa Maria, 1995. 127p. Dissertação (Mestrado). Universidade Federal de Santa Maria. 
PRUITT, W.O.; LOURENCE, F.G. (Ed) Water science and engineering. University of Califórnia, Davis: Dep. of Water Science and Engineering, 1968. v.1, p.41-47: Correlating climatological data with water management of crops.

QUEIROZ, J.E.; CALHEIROS, C.B.M.; PESSOA, P.C.; FRIZZONE, J.A. Estratégias ótimas de irrigação do feijoeiro: Terra como fator limitante da produção. Pesquisa Agropecuária Brasileira, v.31, n. 1, p.55-61, 1996.

REICHARDT, K; LIBARDI, P.L.; SANTOS, J.M. dos. An analysis of soil-water movement in the field. II - Water balance in snap bean crop. Piracicaba: CENA, 1974. 20p. (CENA. Boletim Científico, 22).

RICHARDS, S.J.; MARSH, A.W. Irrigation based on soil measurements. Soil Science of América Proceedings, v.25, n.1, p.65-69, 1961.

ROBINS, J.S.; MUSICK, J.T; FINFROCK, D.C. RHODES, H.F. Grain in field crops. In: HAGAN, R.M.; HAISE, R.H.; EDMINISTER, T.W. et al. (Ed.) Irrigation of agricultural lands. Moisture deficits in relation to the growth and development of dry beans. Irrigation of agricultural lands. Madison, Wiscosin, USA. America Society of Agronomy, 1967. p.622-639.

SAAD, A.M.; LIBARDI, P.L. Uso prático do tensiômetro pelo agricultor irrigante. São Paulo: IPT, 1992. 27p.

SAAD, A.M.; LIBARDI, P.L. Qualidade da irrigação controlada por tensiômetros, em pivô central. Scientia Agricola, v.51, n.3, p.549-555, set./dez. 1994. 
SILVA, H.T. da Caracterização morfológica, agronômica e fenológica de cultivares de feijão (Phaseolus vulgaris $\mathrm{L}$ ) comumente plantados em diversas regiōes do Brasil. Goiânia: EMBRAPA, CNPAF1981, 51p. (EMBRAPA CNPAF. Circular Técnica, 15).

SILVA, V.M. Calibração de blocos de resistência elétrica para estimativa da umidade do solo. In: REUNIÃO PAULISTA DE INICIAÇÃO CIENTÍFICA, 1,; CONGRESSO DE INICIAÇÃO CIENTÍFICA DA ESALQ, 4., Piracicaba, 1989. Anais. Piracicaba, ESALQ, 1989. p.32

SILVEIRA, P.M. da.; MOREIRA, J.A.A. Resposta do feijoeiro a doses de fósforo e lâminas de água de irrigação. Revista Brasileira de Ciência do Solo, v.14, n.1, p.63-67, 1990.

SINGH, G.; SINGH, P.W.; BHUSHAN, E.L.S. Water use and wheat yields in northern Índia under different irrigation regimes. Agricultural Water and Management, v.3, p.107-114, 1980.

SOUSA, D.M.G. de; CARVALHO, L.J.C.B.; MIRANDA, L.N. Correção da acidez do solo. In: Solos dos Cerrados. São Paulo:Nobel; Brasília:EMBRAPA-CPAC, 1986. p.99-127.

SPAANS, E.J.A; BAKER, J.M. Calibrating of watermak soil moisture sensors for soil matric potential and temperature. Plant and Soil, v.143, n.2, p.213-217, 1992.

STENMMETZ, S. Evatranspiração máxima no cultivo do feijão de inverno. Goiânia: EMBRAPA, CNPAF, 1984. 4 p. (EMBRAPA-CNPAF. Pesquisa em Andamento, 47). 
STONE, L.F.; MOREIRA, J.A. Irrigação do feijoeiro. Goiânia: EMBRAPA,CNPAF, 1986. 31 p. (EMBRAPA. CNPAF. Circular Técnica, 23).

STONE, L.F.; MOREIRA, J.A.A. Resposta de duas cultivares de feijão a diferentes lâminas de irrigação, sob diferentes preparos do solo. In: CONGRESSO BRASILEIRO DE CIÊNCIA DO SOLO, 25, Viçosa, 1995. Resumos expandidos. Viçosa: SBCS; UFV, 1995. p. 1743-1745.

STONE, L.F.; MOREIRA, J.A.A.; SILVA,S.C. Efeitos da tensão de água do solo sobre a produtividade e crescimento do feijoeiro. Pesquisa Agropecuária Brasileira, v.23, n.2, p.161-167, 1988.

TANNER, C.B. Gipsum moisture block calibration based on eletrical conductivity in destilled water. Soil Science Society of America Proceedings, v.1, n.1, p.62-65, 1949.

TANNER, C.B.; LEMON, E.R. Radiante energy utilized in evapotranspiration. Agronomy Journal, v.54, n.3, p.207-212, 1962.

TEIXEIRA, H.A.; RAMALHO, M.A.P.; LIMA, L.A.P. de; ANDRADE, M.A. de; SANTA-CECÍLIA, F.C. Viabilidade do cultivo do feijão irrigado no período de inverno em Lavras-MG. In: EMPRESA DE PESQUISA AGROPECUÁRIA DE MINAS GERAIS. Projeto Feijão: relatório 73/75. Belo Horizonte, 1978. p.39-40.

VIEIRA, H. J.; LIBARDI, P.L.; BERGAMASCHI, H.; ANGELOCCI, L.R. Comportamento de duas variedades de feijoeiro sob dois regimes de disponibilidade hidrica do solo. I. Extração de água do solo e evapotranspiração. Pesquisa Agropecuária Brasileira, v.24, n.2, p.165-176, 1989.

WOLF, J. Water constraints to corn production in Central Brasil. Ithaca, 1975. 199p. Thesis (Ph.D.) - Cornel University. Cornell. 


\section{A NEX O I}

Tabela 21 - Valores de tensão da água no solo em $\mathrm{kPa}$ antes de serem efetuadas as irrigações, obtidos através de tensiômetros para os tratamentos T1, T2 e T3 e blocos de gesso T4, T5 e T6 e lâminas de água, para o ano de 1988 (a irrigação em 06/06/88 corresponde a 12 dias após a semeadura).

\begin{tabular}{|c|c|c|c|c|c|c|c|}
\hline \multirow[t]{2}{*}{ Dia/mês/ano } & \multicolumn{6}{|c|}{ Profundidade dos tensiômetros $(\mathrm{cm})$} & \multirow{2}{*}{$\begin{array}{r}\text { Lâminas } \\
(\mathrm{mm})\end{array}$} \\
\hline & 10 & 20 & 30 & 40 & 60 & 80 & \\
\hline \multicolumn{8}{|c|}{ Tratamento $\mathrm{T} 1(33 \mathrm{kPa})$} \\
\hline $06 / 06 / 88$ & 33,45 & 22,70 & 22,59 & 24,20 & 24,71 & 24,85 & 28,61 \\
\hline $10 / 06 / 88$ & 30,48 & 30,74 & 15,79 & 15,55 & 20,76 & 21,89 & 24,41 \\
\hline $14 / 06 / 88$ & 35,79 & 19,74 & 17,40 & 17,41 & 20,76 & 22,13 & 25,95 \\
\hline $18 / 06 / 88$ & 37,28 & 13,81 & 18,02 & 17,16 & 19,52 & 20,03 & 24,90 \\
\hline $22 / 06 / 88$ & 35,79 & 18,50 & 16,53 & 15,31 & 18,53 & 19,66 & 24,86 \\
\hline $26 / 06 / 88$ & 34.68 & 14,43 & 17,27 & 15,18 & 18,41 & 18,67 & 24,18 \\
\hline $03 / 07 / 88$ & 47,90 & 15,04 & 21,48 & 18,64 & 19,15 & 20,90 & 26,87 \\
\hline $07 / 07 / 88$ & 52,47 & 32,34 & 22,71 & 19,26 & 23,23 & 22,50 & 30,57 \\
\hline $10 / 07 / 88$ & 40,74 & 23,32 & 20,86 & 18,02 & 24,09 & 22,75 & 28,14 \\
\hline $13 / 07 / 88$ & 36,66 & 23,07 & 19,99 & 18,02 & 24,47 & 23,99 & 27,62 \\
\hline $16 / 07 / 88$ & 27,14 & 20,23 & 19,38 & 18,27 & 24,09 & 22,75 & 26,03 \\
\hline $19 / 07 / 88$ & 28,01 & 19,99 & 19,99 & 17,78 & 25,33 & 23,99 & 26,29 \\
\hline $22 / 07 / 88$ & 30,85 & 24,31 & 22,71 & 20,50 & 26,57 & 24,97 & 28,27 \\
\hline $26 / 07 / 88$ & 40,37 & 28,39 & 25,18 & 22,97 & 29,65 & 26,46 & 30,88 \\
\hline $29 / 07 / 88$ & 28,38 & 26,16 & 26,42 & 25,44 & 37,07 & 29,55 & 30,62 \\
\hline $01 / 08 / 88$ & 26,90 & 23,07 & 24,57 & 23,71 & 45,72 & 32,02 & 30,33 \\
\hline $05 / 08 / 88$ & 42,96 & 29,87 & 27,65 & 25,44 & 55,11 & 36,71 & 34,24 \\
\hline $09 / 08 / 88$ & 40,98 & 15,91 & 26,17 & 23,58 & 63,02 & 40,67 & 32,14 \\
\hline $12 / 08 / 88$ & 32,70 & 30,49 & 27,90 & 25,44 & 70,43 & 45,61 & 34,36 \\
\hline $16 / 08 / 88$ & 41.60 & 22,21 & 21,48 & 25,44 & 74,14 & 50,55 & 33,48 \\
\hline Mínimo: & 26,90 & 13,81 & 15,79 & 15,18 & 18,41 & 18,67 & 24,18 \\
\hline Máximo: & 52.47 & 32,34 & 27,90 & 25,44 & 74,14 & 50,55 & 34,36 \\
\hline Média: & 36.26 & 22,72 & 21,70 & 20,37 & 33,24 & 27,53 & 28,64 \\
\hline Desvio padrão: & 6.96 & 5,66 & 3,73 & 3,75 & 18,15 & 9.03 & 3,29 \\
\hline Lâm. ap. (mm): & - & 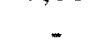 & 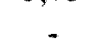 & 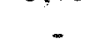 & - & - & 572,75 \\
\hline Núm. de irrigaçōes & - & - & - & - & - & - & 20 \\
\hline Lâm. inicial (mm) & - & - & - & - & - & - & 50 \\
\hline Precipitação (mm) & - & - & - & - & - & - & 0 \\
\hline Lâmina total (mm) & - & - & - & - & - & - & 622,75 \\
\hline
\end{tabular}


Tabela 21 - Continuação.

\begin{tabular}{|c|c|c|c|c|c|c|c|}
\hline \multirow[t]{2}{*}{ Dia/mês/ano } & \multicolumn{6}{|c|}{ Profundidade dos tensiômetros $(\mathrm{cm})$} & \multirow{2}{*}{$\begin{array}{r}\text { Lâminas } \\
(\mathrm{mm})\end{array}$} \\
\hline & 10 & 20 & 30 & 40 & 60 & 80 & \\
\hline \multicolumn{8}{|c|}{ Tratamento T2 $(50 \mathrm{kPa})$} \\
\hline 04/06/88 & 31,59 & 22,09 & 20,24 & 20,74 & 21,75 & 21,39 & 10,00 \\
\hline $08 / 06 / 88$ & 46,17 & 23,45 & 21,97 & 20,50 & 21,87 & 21,27 & 29,04 \\
\hline $15 / 06 / 88$ & 46,67 & 23,69 & 20,86 & 19,26 & 21,99 & 21,52 & 28,57 \\
\hline $22 / 06 / 88$ & 41,97 & 18,50 & 16,53 & 15,31 & 18,53 & 19,66 & 29,19 \\
\hline $28 / 06 / 88$ & 49,14 & 24,93 & 20,98 & 20,74 & 20,88 & 20,28 & 29,08 \\
\hline 03/07/88 & 46,91 & 23,32 & 18,63 & 18,64 & 22,98 & 22,38 & 28,26 \\
\hline 08/07/88 & 60,75 & 26,16 & 19,00 & 18,02 & 23,23 & 22,13 & 29,70 \\
\hline $12 / 07 / 88$ & 58,65 & 28,63 & 20,24 & 19,88 & 30,27 & 23,74 & 31,14 \\
\hline $16 / 07 / 88$ & 54,33 & 33,33 & 25,18 & 23,83 & 29,04 & 25,22 & 32,64 \\
\hline $20 / 07 / 88$ & 53,34 & 32,09 & 26,17 & 25,44 & 32,13 & 26,21 & 29,30 \\
\hline $24 / 07 / 88$ & 46,67 & 32,59 & 27,04 & 27,54 & 36,20 & 28,93 & 33,49 \\
\hline $28 / 07 / 88$ & 56,80 & 49,02 & 40,88 & 39,65 & 44,48 & 32,39 & 35,14 \\
\hline $02 / 08 / 88$ & 57,91 & 30,86 & 24,94 & 27,91 & 52,76 & 37,33 & 33,54 \\
\hline $06 / 08 / 88$ & 37,89 & 28,02 & 25,80 & 30,63 & 52,51 & 37,83 & 33,79 \\
\hline $10 / 08 / 88$ & 39,99 & 23,69 & 22,84 & 26,67 & 54,86 & 38,94 & 32,71 \\
\hline $14 / 08 / 88$ & 53,09 & 28,88 & 28,89 & 36,06 & 59,56 & 41,66 & 36,67 \\
\hline $18 / 08 / 88$ & 55,19 & 28,39 & 43,22 & 42.37 & 61,16 & 45,12 & 38,94 \\
\hline Mínimo: & 31,59 & 18,50 & 16,53 & 15,31 & 18,53 & 19,66 & 10,00 \\
\hline Máximo: & 60,75 & 49,02 & 43,22 & 42,37 & 61,16 & 45,12 & 38,94 \\
\hline Média: & 49,24 & 28,10 & 24,91 & 25,48 & 35,54 & 28,59 & 30,66 \\
\hline Desvio padrão: & 8,11 & 6,78 & 7,27 & 7,84 & 15,26 & 8,49 & 6,16 \\
\hline Lâm. ap. (mm): & - & - & - & - & - & - & 521,20 \\
\hline Núm. de irrigações & - & - & - & - & - & - & 17 \\
\hline Lâm. inicial (mm) & - & - & - & - & - & - & 50 \\
\hline Precipitação (mm) & - & - & - & - & - & - & 0 \\
\hline Lâmina total (mm) & - & - & - & - & - & - & 571,20 \\
\hline
\end{tabular}


Tabela 21 - Continuação.

\begin{tabular}{|c|c|c|c|c|c|c|c|}
\hline \multirow[t]{2}{*}{$\mathrm{Dia} / \mathrm{mês} / \mathrm{ano}$} & \multicolumn{6}{|c|}{ Profundidade dos tensiômetros $(\mathrm{cm})$} & \multirow{2}{*}{$\begin{array}{r}\text { Lâminas } \\
(\mathrm{mm})\end{array}$} \\
\hline & 10 & 20 & 30 & 40 & 60 & 80 & \\
\hline \multicolumn{8}{|c|}{ Tratamento T3 $(70 \mathrm{kPa})$} \\
\hline $09 / 06 / 88$ & 64,83 & 30,49 & 25,18 & 24,45 & 24,34 & 22,75 & 32,51 \\
\hline $16 / 06 / 88$ & 66,93 & 30,24 & 22,46 & 21,11 & 23,23 & 22,13 & 31,57 \\
\hline $24 / 06 / 88$ & 72,86 & 34,81 & 22,46 & 20,50 & 23,48 & 22,13 & 32,38 \\
\hline $02 / 07 / 88$ & 76,82 & 47,79 & 33,34 & 26,92 & 26,44 & 23,86 & 36,46 \\
\hline 07/07/88 & 74,96 & 41,86 & 36,06 & 34,09 & 30,64 & 27,45 & 37,48 \\
\hline $12 / 07 / 88$ & 75,09 & 43,09 & 36,30 & 36,19 & 32,13 & 27,45 & 38,01 \\
\hline $17 / 07 / 88$ & 73,73 & 52,85 & 49.89 & 52,62 & 35.83 & 29,55 & 41,76 \\
\hline $22 / 07 / 88$ & 70,39 & 50,88 & 49,52 & 59,42 & 42,63 & 32,39 & 42,52 \\
\hline $28 / 07 / 88$ & 69,77 & 53,96 & 52,98 & 60,65 & 53,75 & 37,95 & 43,96 \\
\hline $02 / 08 / 88$ & 63,84 & 29,50 & 54,84 & 59,66 & 64,99 & 37.33 & 42,17 \\
\hline 07/08/88 & 65,70 & 42,23 & 50,88 & 64,11 & 67,59 & 53,39 & 43,75 \\
\hline $12 / 08 / 88$ & 47,04 & 42.23 & 59.66 & 67,94 & 65.24 & 49.93 & 43,05 \\
\hline $17 / 08 / 88$ & 65,45 & 55,82 & 55,83 & 68,07 & 59,31 & 61,67 & 44,90 \\
\hline Mínimo: & 47,04 & 29,50 & 22,46 & 20,50 & 23,23 & 22,13 & 31,57 \\
\hline Máximo: & 76,82 & 55.82 & 59,66 & 68,07 & 67,59 & 61,67 & 44,90 \\
\hline Média: & 68,26 & 42,75 & 42,26 & 45,83 & 42,28 & 34,46 & 39,27 \\
\hline Desvio padrão: & 7,75 & 9,30 & 13,46 & 18,84 & 17.50 & 13,04 & 4,82 \\
\hline Lâm. ap. (mm): & - & - & - & - & - & - & 510,52 \\
\hline Núm. de irrigações & - & - & - & - & - & - & 13 \\
\hline Lâm. inicial (mm) & - & - & - & - & - & - & 50 \\
\hline Precipitação (mm) & - & - & - & - & - & - & 0 \\
\hline Lâmina total (mm) & - & - & - & - & - & - & 560,52 \\
\hline
\end{tabular}

Tratamento T4 $(100 \mathrm{kPa})$

\begin{tabular}{lrrrrrrr}
\hline $15 / 06 / 88$ & 127,31 & 57,28 & 51,69 & 48,69 & - & - & 35,81 \\
$26 / 06 / 88$ & 146,23 & 69,36 & 56,47 & 50,15 & - & - & 39,14 \\
$04 / 07 / 88$ & 146,23 & 77,81 & 64,01 & 52,62 & - & - & 41,29 \\
$11 / 07 / 88$ & 172,75 & 59,45 & 91,53 & 70,05 & - & - & 44,43 \\
$18 / 07 / 88$ & 166,47 & 123,23 & 123,23 & 100,76 & - & - & 48,71 \\
$24 / 07 / 88$ & 146,23 & 127,31 & 131,28 & 127,31 & - & - & 50,74 \\
$31 / 07 / 88$ & 166,47 & 131,28 & 153,23 & 153,23 & - & - & 52,44 \\
$07 / 08 / 88$ & 172,75 & 131,28 & 138,93 & 156,63 & - & - & 52,74 \\
$13 / 08 / 88$ & 146,23 & 87,72 & 75,94 & 131,28 & - & - & 50,54 \\
\hline Mínimo: & 127,31 & 57,28 & 51,69 & 48,69 & - & - & 35,81 \\
Máximo: & 127,31 & 57,28 & 51,69 & 48,69 & - & - & 35,81 \\
Média: & 154,52 & 96,08 & 98,48 & 98,97 & - & - & 46,20 \\
Desvio padrão: & 15,67 & 31,93 & 38,76 & 44,74 & - & - & 6,25 \\
Lâm. ap. (mm): & - & - & - & - & - & - & 415,84 \\
Núm. de irrigações & - & - & - & - & - & - & 9 \\
Lâm. inicial (mm) & - & - & - & - & - & - & - \\
Precipitação (mm) & - & - & - & - & - & - & - \\
Lâmina total (mm) & - & - & - & - & - & - & 465,84 \\
\hline
\end{tabular}


Tabela 21 - Continuação.

\begin{tabular}{|c|c|c|c|c|c|c|c|}
\hline \multirow[t]{2}{*}{ Dia/mês/ano } & \multicolumn{6}{|c|}{ Profundidade dos tensiômetros $(\mathrm{cm})$} & \multirow{2}{*}{$\begin{array}{r}\text { Lâminas } \\
(\mathrm{mm})\end{array}$} \\
\hline & 10 & 20 & 30 & 40 & 60 & 80 & \\
\hline \multicolumn{8}{|c|}{ Tratamento T5 $(500 \mathrm{kPa})$} \\
\hline $18 / 06 / 88$ & 163,25 & 60,10 & 50,15 & 49,44 & - & - & 39,57 \\
\hline $02 / 07 / 88$ & 379,89 & 193,36 & 68,65 & 57,28 & - & - & 45,83 \\
\hline $11 / 07 / 88$ & 431,82 & 241,60 & 166,47 & 166,47 & - & - & 54,52 \\
\hline $22 / 07 / 88$ & 338,70 & 222,39 & 193,36 & 209,63 & - & - & 55,82 \\
\hline $01 / 08 / 88$ & 410,26 & 261,75 & 219,89 & 246,20 & - & - & 57,37 \\
\hline $11 / 08 / 88$ & 438,80 & 282,67 & 232,17 & 272,38 & - & - & 58 \\
\hline Mínimo: & 163,25 & 60,10 & 50,15 & 49,44 & 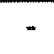 & - & 39,57 \\
\hline Máximo: & 438,80 & 282,67 & 232,17 & 272,38 & - & - & 58,00 \\
\hline Média: & 360,45 & 210,31 & 155,11 & 166,90 & - & - & 51,85 \\
\hline Desvio padrão: & 103,40 & 79,82 & 77,74 & 94,93 & - & - & 7,46 \\
\hline Lâm. ap. (mm): & - & - & - & - & - & - & 311,11 \\
\hline Núm. de irrigações & - & $=$ & - & - & - & - & 6 \\
\hline Lâm. inicial (mm) & - & - & - & - & - & - & 50 \\
\hline Precipitação (mm) & - & - & - & - & - & - & 0 \\
\hline Lâmina total (mm) & - & - & - & - & - & - & 361,11 \\
\hline \multicolumn{8}{|c|}{ Tratamento T6 $(1000 \mathrm{kPa})$} \\
\hline $21 / 06 / 88$ & 864,18 & 193,36 & 60,10 & 51,45 & - & - & 46,19 \\
\hline $05 / 07 / 88$ & 902,16 & 329,93 & 163,25 & 84,34 & $=$ & - & 52,05 \\
\hline $17 / 07 / 88$ & 938,82 & 395,33 & 193,36 & 156,63 & - & - & 57,69 \\
\hline $29 / 07 / 88$ & 938,82 & 336,96 & 232,17 & 198,91 & - & - & 58,62 \\
\hline $10 / 08 / 88$ & 938,82 & 352.33 & 272,38 & 250,73 & - & - & 59,71 \\
\hline Mínimo: & 864,18 & 193,36 & 60,10 & 51,45 & - & - & 46,19 \\
\hline Máximo: & 938,82 & 395,33 & 272,38 & 250,73 & - & - & 59,71 \\
\hline Média: & 916,56 & 321,58 & 184,25 & 148,41 & - & - & 54,85 \\
\hline Desvio padrão: & 33,31 & 76,04 & 80,62 & 81,54 & - & - & 5,67 \\
\hline Lâm. ap. (mm): & - & - & - & - & - & - & 274,26 \\
\hline Núm. de irrigações & - & - & - & - & - & - & 5 \\
\hline Lâm. inicial (mm) & - & - & * & - & - & - & 50 \\
\hline Precipitação (mm) & - & - & - & - & - & - & 0 \\
\hline Lâmina total (mm) & $=$ & - & - & - & - & - & 324,26 \\
\hline
\end{tabular}


Tabela 22 - Valores de tensão da água no solo em $\mathrm{kPa}$ antes de serem efetuadas as irrigações, obtidos através de tensiômetros para os tratamentos T1, T2 e T3 e blocos de gesso T4, T5 e T6 e lâminas de água, para o ano de 1990 (a irrigação em 13/06/90 corresponde a 16 dias após a semeadura).

\begin{tabular}{|c|c|c|c|c|c|c|c|}
\hline \multirow[t]{2}{*}{ Dia/mês/ano } & \multicolumn{6}{|c|}{ Profundidade dos tensiômetros $(\mathrm{cm})$} & \multirow{2}{*}{$\begin{array}{l}\text { Lâminas } \\
(\mathrm{mm})\end{array}$} \\
\hline & 10 & 20 & 30 & 40 & 60 & 80 & \\
\hline \multicolumn{8}{|c|}{ Tratamento $\mathrm{Tl}(33 \mathrm{kPa})$} \\
\hline $13 / 06 / 90$ & 41,97 & 10,10 & 13,69 & 13,70 & 14,83 & 16,33 & 9,29 \\
\hline $16 / 06 / 90$ & 45,43 & 18,75 & 13,44 & 15,55 & 16,06 & 17,19 & 9,55 \\
\hline $18 / 06 / 90$ & 25,91 & 17,27 & 16,53 & 16,54 & 17,30 & 17,56 & 8,24 \\
\hline $21 / 06 / 90$ & 34,56 & 18,50 & 16,29 & 17,41 & 17,92 & 17,81 & 9,62 \\
\hline $24 / 06 / 90$ & 41,97 & 19,99 & 15,92 & 17,78 & 18,29 & 17,56 & 11,46 \\
\hline $27 / 06 / 90$ & 41,97 & 23,32 & 17,77 & 19,01 & 19,40 & 19,04 & 11,75 \\
\hline $30 / 06 / 90$ & 40,74 & 21,84 & 17,77 & 19,88 & 19,77 & 19,04 & 11,57 \\
\hline $03 / 07 / 90$ & 38,88 & 24,93 & 18,76 & 20,50 & 21,01 & 19,66 & 13,15 \\
\hline $05 / 07 / 90$ & 40,83 & 26,78 & 18,76 & 22,35 & 22,24 & 20,90 & 13,56 \\
\hline $09 / 07 / 90$ & 37,65 & 24,93 & 17.77 & 21,73 & 24,71 & 21,52 & 12,08 \\
\hline $11 / 07 / 90$ & 38,02 & 31,11 & 20,24 & 23,96 & 25,95 & 22,50 & 15,41 \\
\hline $20 / 07 / 90$ & 34,32 & 16,28 & 12,83 & 11,85 & 9,88 & 10,15 & 17,99 \\
\hline $21 / 07 / 90$ & 33,94 & 19,37 & 15,30 & 14,07 & 11,74 & 11,01 & 8,74 \\
\hline $23 / 07 / 90$ & 29,37 & 21,84 & 18,76 & 16,79 & 14,21 & 12,62 & 10,01 \\
\hline $26 / 07 / 90$ & 37,03 & 23,07 & 20,86 & 21,11 & 15,45 & 14,72 & 12,22 \\
\hline $28 / 07 / 90$ & 44,44 & 29,25 & 22,09 & 24,20 & 17,92 & 15,96 & 14,38 \\
\hline $30 / 07 / 90$ & 44,44 & 26,16 & 22,71 & 26,06 & 19,15 & 16,57 & 14,35 \\
\hline $02 / 08 / 90$ & 45,68 & 31,72 & 20,24 & 21,73 & 19,77 & 18,43 & 14,96 \\
\hline $05 / 08 / 90$ & 35,79 & 45,93 & 19,99 & 39,03 & 25,95 & 19,04 & 16,54 \\
\hline $07 / 08 / 90$ & 35,18 & 42,84 & 20,86 & 45,83 & 29,04 & 21,27 & 16,95 \\
\hline $10 / 08 / 90$ & 32,70 & 32,96 & 20,24 & 37,55 & 24,71 & 21,52 & 18,58 \\
\hline $13 / 08 / 90$ & 37,28 & 36,67 & 21,48 & 33,84 & 21.99 & 21,27 & 16,72 \\
\hline $16 / 08 / 90$ & 39,50 & 36,05 & 29.51 & 33,84 & 22,86 & 21,52 & 20,09 \\
\hline $19 / 08 / 90$ & 39,25 & 34,57 & 22,71 & 35,32 & 34,60 & 22.75 & 21,93 \\
\hline $21 / 08 / 90$ & 35,18 & 41,98 & 22,09 & 31,00 & 26,94 & 23,74 & 17,94 \\
\hline $23 / 08 / 90$ & 34,56 & 35,80 & 20,86 & 39,03 & 24,09 & 23,99 & 20,69 \\
\hline $26 / 08 / 90$ & 45,06 & 34,57 & 21,48 & 32,23 & 18,29 & 22,50 & 20,93 \\
\hline $29 / 08 / 90$ & 42,96 & 34,57 & 22,46 & 39,03 & 20,39 & 22,75 & 21,59 \\
\hline Mínimo: & 25,91 & 10,10 & 12,83 & 11,85 & 9,88 & 10,15 & 8,24 \\
\hline Máximo: & 45,68 & 45,93 & 29,51 & 45,83 & 34,60 & 23,99 & 21,93 \\
\hline Média: & 38,38 & 27,90 & 19,34 & 25,39 & 20,52 & 18,89 & 14,65 \\
\hline Destio padrão: & 4,94 & 8,92 & 3,51 & 9,46 & 5,36 & 3,68 & 4,22 \\
\hline Lâm. ap. (mm): & 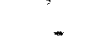 & - & - & - & - & - & 410,29 \\
\hline Núm. de irrigações & - & - & - & - & - & - & 28 \\
\hline Lâm. inicial (mm) & - & - & - & - & - & - & 50 \\
\hline Precipitação (mm) & - & - & - & - & - & - & 67,7 \\
\hline Lâmina total (mm) & - & - & - & - & - & - & 527,99 \\
\hline
\end{tabular}


Tabela 22 - Continuação.

\begin{tabular}{|c|c|c|c|c|c|c|c|}
\hline \multirow[t]{2}{*}{ Dia/mês/ano } & \multicolumn{6}{|c|}{ Profundidade dos tensiômetros $(\mathrm{cm})$} & \multirow{2}{*}{$\begin{array}{r}\text { Lâminas } \\
(\mathrm{mm})\end{array}$} \\
\hline & 10 & 20 & 30 & 40 & 60 & 80 & \\
\hline \multicolumn{8}{|c|}{ Tratamento T2 ( $50 \mathrm{kPa})$} \\
\hline $17 / 06 / 90$ & 59,27 & 34,57 & 24,19 & 21,73 & 21,99 & 21,52 & 15,92 \\
\hline $21 / 06 / 90$ & 50,99 & 35,68 & 26,17 & 23,58 & 22,24 & 22,13 & 16,07 \\
\hline $25 / 06 / 90$ & 58,03 & 40,74 & 29,51 & 25,44 & 23,48 & 22,50 & 17,68 \\
\hline $29 / 06 / 90$ & 63,97 & 48,16 & 31,98 & 27,29 & 25,33 & 23,99 & 19,14 \\
\hline $02 / 07 / 90$ & 55,56 & 50,63 & 34,82 & 28,90 & 25,95 & 24,97 & 19,32 \\
\hline $06 / 07 / 90$ & 69,77 & 58,04 & 35,07 & 30,13 & 26,57 & 25,22 & 20,77 \\
\hline 07/07/90 & 66,68 & 45,32 & 47,18 & 35,94 & 29,65 & 28,31 & 21,41 \\
\hline $11 / 07 / 90$ & 47,53 & 45,69 & 28,64 & 26,06 & 25,95 & 25,84 & 18,83 \\
\hline $20 / 07 / 90$ & 61,74 & 19,99 & 14,68 & 11,60 & 10,50 & 9,78 & 10,11 \\
\hline $22 / 07 / 90$ & 60,51 & 37,28 & 21,97 & 14,94 & 11,74 & 11,01 & 14,08 \\
\hline $25 / 07 / 90$ & 62,73 & 53,96 & 32,35 & 20,50 & 14,83 & 13,85 & 18,5 \\
\hline $28 / 07 / 90$ & 51,72 & 71,26 & 46,81 & 31,00 & 21,99 & 19,66 & 22,05 \\
\hline $30 / 07 / 90$ & 55,56 & 70,03 & 50,88 & 34,70 & 24,47 & 21,27 & 22,48 \\
\hline $02 / 08 / 90$ & 59,02 & 61,75 & 43,72 & 36,31 & 28,17 & 23,37 & 21,84 \\
\hline $05 / 08 / 90$ & 48,15 & 52,73 & 39,02 & 36,56 & 30,27 & 25,47 & 21,64 \\
\hline $08 / 08 / 90$ & 51,60 & 64,22 & 42,23 & 37,18 & 32,74 & 27,69 & 22,83 \\
\hline $12 / 08 / 90$ & 50,37 & 64,47 & 41,86 & 37,18 & 33,11 & 29,55 & 22,76 \\
\hline $15 / 08 / 90$ & 49,39 & 66,94 & 45,94 & 40,02 & 33,36 & 31,15 & 22,01 \\
\hline $18 / 08 / 90$ & 52,47 & 56,81 & 37,29 & 36,56 & 30,89 & 32,02 & 20,69 \\
\hline $21 / 08 / 90$ & 51,23 & 59,52 & 41,86 & 41,25 & 32,13 & 32,64 & 22,89 \\
\hline $24 / 08 / 90$ & 53,09 & 61,38 & 43,72 & 44,96 & 33,36 & 33,87 & 23,53 \\
\hline $27 / 08 / 90$ & 46,91 & 63,85 & 49,65 & 49,53 & 36,45 & 35,11 & 24,14 \\
\hline Mínimo: & 46,91 & 19,99 & 14,68 & 11,60 & 10,50 & 9,78 & 10,11 \\
\hline Máximo: & 69,77 & 71,26 & 50,88 & 49,53 & 36,45 & 35,11 & 24,14 \\
\hline Média: & 55,74 & 52,86 & 36,80 & 31,42 & 26,14 & 24,59 & 19,94 \\
\hline Desvio padrão: & 6,50 & 13,26 & 9,73 & 9.47 & 7,02 & 6,85 & 3,47 \\
\hline Lâm. ap. (mm): & - & - & - & - & - & - & 438,69 \\
\hline Núm. de irrigações & - & - & - & - & - & - & 22 \\
\hline Lâm. inicial (mm) & - & - & - & - & - & - & 50 \\
\hline Precipitação (mm) & - & - & - & - & - & - & 67,7 \\
\hline Lâmina total (mm) & - & - & - & . & - & - & 556,39 \\
\hline
\end{tabular}


Tabela 22 - Continuação.

\begin{tabular}{|c|c|c|c|c|c|c|c|}
\hline \multirow[t]{2}{*}{ Dia/mês/ano } & \multicolumn{6}{|c|}{ Profundidade dos tensiômetros $(\mathrm{cm})$} & \multirow{2}{*}{$\begin{array}{r}\text { Lâminas } \\
(\mathrm{mm})\end{array}$} \\
\hline & 10 & 20 & 30 & 40 & 60 & 80 & \\
\hline \multicolumn{8}{|c|}{ Tratamento $\mathrm{T} 3(70 \mathrm{kPa})$} \\
\hline $17 / 06 / 90$ & 59,27 & 33,82 & 25,68 & 24,45 & 22,86 & 22,75 & 16,47 \\
\hline $24 / 06 / 90$ & 72,61 & 39,14 & 28,27 & 26,67 & 24,71 & 22,75 & 18,34 \\
\hline $29 / 06 / 90$ & 69,15 & 45,32 & 36,92 & 30,38 & 27,18 & 25,84 & 20,08 \\
\hline $03 / 07 / 90$ & 62,98 & 43,46 & 38,77 & 32,85 & 28,42 & 26,21 & 20,06 \\
\hline $07 / 07 / 90$ & 66,68 & 45,32 & 47,18 & 35,94 & 29,65 & 28,31 & 21,41 \\
\hline $12 / 07 / 90$ & 69,15 & 45,93 & 46,19 & 37,79 & 30,27 & 28,93 & 21,69 \\
\hline $21 / 07 / 90$ & 65,45 & 22,46 & 16,29 & 14,94 & 10,50 & 10,15 & 19,3 \\
\hline $27 / 07 / 90$ & 71,63 & 43,46 & 35,07 & 33,47 & 18,29 & 15,09 & 20,22 \\
\hline $30 / 07 / 90$ & 64,83 & 43,46 & 40,63 & 45,83 & 22,24 & 17,19 & 31,75 \\
\hline $07 / 08 / 90$ & 67,92 & 59,28 & 61,02 & 73,63 & 39,54 & 25,22 & 30,83 \\
\hline $12 / 08 / 90$ & 71,01 & 64,47 & 81,40 & 53,24 & 46,34 & 31,03 & 32,53 \\
\hline $17 / 08 / 90$ & 66,68 & 53,10 & 64,72 & 72,39 & 54,37 & 33,25 & 32,03 \\
\hline $23 / 08 / 90$ & 29,00 & 53,96 & 63,24 & 67,20 & 59,93 & 38,81 & 25,21 \\
\hline $27 / 08 / 90$ & 50,37 & 40,99 & 36,30 & 34,09 & 57,46 & 41,90 & 30,3 \\
\hline Mínimo: & 29,00 & 22,46 & 16,29 & 14,94 & 10,50 & 10,15 & 16,47 \\
\hline Máximo: & 72,61 & 64,47 & 81,40 & 73,63 & 59,93 & 41,90 & 32,53 \\
\hline Média: & 63,34 & 45,30 & 44,41 & 41,63 & 33,70 & 26,25 & 24,30 \\
\hline Desvio padrão: & 11,42 & 10,45 & 17,71 & 18,36 & 15,38 & 8,67 & 5,90 \\
\hline Lâm. ap. (mm): & - & - & - & - & - & - & 340,22 \\
\hline Núm. de irrigações & - & - & - & $\sim$ & - & - & 14 \\
\hline Lâm. inicial (mm) & - & - & - & $=$ & - & - & 50 \\
\hline Precipitação (mm) & - & - & - & - & - & - & 67,7 \\
\hline Lâmina total (mm) & - & - & - & - & - & - & 457,92 \\
\hline
\end{tabular}

Tratamento T4 $(100 \mathrm{kPa})$

\begin{tabular}{lcccccrr}
\hline $18 / 06 / 90$ & 201,64 & 61,91 & 64,01 & 57,28 & - & - & 27 \\
$26 / 06 / 90$ & 219,89 & 63,00 & 61,91 & 58,04 & - & - & 29,19 \\
$02 / 07 / 90$ & 131,28 & 69,01 & 63,51 & 58,76 & - & - & 36,91 \\
$11 / 07 / 90$ & 138,93 & 114,70 & 68,28 & 63,00 & - & - & 28,36 \\
$24 / 07 / 90$ & 123,23 & 204,33 & 64,96 & 60,73 & - & - & 37,09 \\
$01 / 08 / 90$ & 193,36 & 73,39 & 67,11 & 65,42 & - & - & 33,29 \\
$09 / 08 / 90$ & 163,25 & 83,18 & 68,65 & 59,28 & - & - & 35,12 \\
$18 / 08 / 90$ & 178,85 & 73,39 & 67,11 & 68,28 & - & - & 38,34 \\
\hline Mínimo: & 123,23 & 61,91 & 61,91 & 57,28 & - & - & 27,00 \\
Máximo: & 219,89 & 204,33 & 68,65 & 68,28 & - & - & 38,34 \\
Média: & 168,80 & 92,86 & 65,69 & 61,35 & - & - & 33,16 \\
Desvio padrão: & 35,46 & 48,07 & 2,45 & 3,89 & - & - & 4,42 \\
Lâm. ap. (mm): & - & - & - & - & - & - & 265,3 \\
Núm. de irrigações & - & - & - & - & - & - & 8 \\
Lâm. inicial (mm) & - & - & - & - & - & - & 50 \\
Precipitação (mm) & - & - & - & - & - & - & 67,7 \\
Lâmina total (mm) & - & - & - & - & - & - & 383,00 \\
\hline
\end{tabular}


Tabela 22 - Continuação

\begin{tabular}{|c|c|c|c|c|c|c|c|}
\hline \multirow[t]{2}{*}{ Dia/mês/ano } & \multicolumn{6}{|c|}{ Profundidade dos tensiômetros $(\mathrm{cm})$} & \multirow{2}{*}{$\begin{array}{r}\text { Lâminas } \\
(\mathrm{mm})\end{array}$} \\
\hline & 10 & 20 & 30 & 40 & 60 & 80 & \\
\hline \multicolumn{8}{|c|}{ Tratamento T5 $(500 \mathrm{kPa})$} \\
\hline $19 / 06 / 90$ & 379,89 & 66,71 & 64,49 & 60,10 & - & - & 36,24 \\
\hline $29 / 06 / 90$ & 387,67 & 65,86 & 65,42 & 61,33 & - & - & 36,34 \\
\hline $26 / 07 / 90$ & 379,89 & 241,60 & 67,11 & 66,71 & - & - & 34,29 \\
\hline $04 / 08 / 90$ & 573,76 & 227,33 & 172,75 & 131,28 & - & - & 35,91 \\
\hline $14 / 08 / 90$ & 379,89 & 222,39 & 227,33 & 227,33 & - & - & 34,26 \\
\hline $24 / 08 / 90$ & 685.59 & 236,93 & 227,33 & 239,27 & - & - & 38,23 \\
\hline Mínimo: & 379,89 & 65,86 & 64,49 & 60,10 & $=$ & - & 34,26 \\
\hline Máximo: & 685,59 & 241,60 & 227,33 & 239,27 & - & - & 38,23 \\
\hline Média: & 464,45 & 176,80 & 137,41 & 131,00 & - & - & 35,88 \\
\hline Desvio padrão: & 132,81 & 85,88 & 81,07 & 83,69 & - & - & 1,48 \\
\hline Lâm. ap. (mm): & - & - & - & - & - & - & 215,27 \\
\hline Núm. de irrigações & - & - & - & - & - & - & 6 \\
\hline Lâm. inicial (mm) & - & - & - & - & - & - & 50 \\
\hline Precipitação (mm) & - & - & - & - & - & - & 67,7 \\
\hline Lâmina total (mm) & - & - & - & - & - & - & 332,97 \\
\hline \multicolumn{8}{|c|}{ Tratamento T6 $(1000 \mathrm{kPa})$} \\
\hline $21 / 06 / 90$ & 938,82 & 731,50 & 562,65 & 57,28 & - & - & 32,53 \\
\hline $02 / 07 / 90$ & 938,82 & 288,69 & 239,27 & 57,28 & - & - & 33,38 \\
\hline $25 / 07 / 90$ & 938,82 & 298,50 & 219,89 & 60,10 & - & - & 33,49 \\
\hline $04 / 08 / 90$ & 1137,17 & 539,86 & 491,57 & 68,28 & - & - & 35,91 \\
\hline $15 / 08 / 90$ & 938,82 & 510,14 & 551,36 & 72,09 & - & - & 35,48 \\
\hline $24 / 08 / 90$ & 1074,57 & 616,44 & 504,02 & 85,48 & - & - & 36,37 \\
\hline Mínimo: & 938,82 & 288,69 & 219,89 & 57,28 & $\cdot$ & - & 32,53 \\
\hline Máximo: & 1137,17 & 731,50 & 562,65 & 85,48 & . & - & 36,37 \\
\hline Média: & 994,50 & 497,52 & 428,13 & 66,75 & - & - & 34,53 \\
\hline Desvio padrão: & 88,51 & 175,53 & 156,26 & 11,00 & - & - & 1,59 \\
\hline Lâm. ap. (mm): & - & - & - & - & - & - & 207,16 \\
\hline Núm. de irrigações & - & - & - & - & - & - & 6 \\
\hline Lâm. inicial (mm) & - & - & - & - & - & - & 50 \\
\hline Precipitação (mm) & - & - & - & - & - & - & 67.7 \\
\hline Lâmina total (mm) & - & - & - & - & - & - & 324,86 \\
\hline
\end{tabular}


Tabela 23 - Valores de tensão da água no solo em $\mathrm{kPa}$ antes de serem efetuadas as irrigações, obtidos através de tensiômetros para os tratamentos T1, T2 e T3 e blocos de gesso T4, T5 e T6 e lâminas de água, para o ano de 1991 (a irrigação em 11/06/91 corresponde a 15 dias após a semeadura).

\begin{tabular}{|c|c|c|c|c|c|c|c|}
\hline \multirow[t]{2}{*}{ Dia/mès/ano } & \multicolumn{6}{|c|}{ Profundidade dos tensiômetros $(\mathrm{cm})$} & \multirow{2}{*}{$\begin{array}{r}\text { Lâminas } \\
(\mathrm{mm})\end{array}$} \\
\hline & 10 & 20 & 30 & 40 & 60 & 80 & \\
\hline \multicolumn{8}{|c|}{ Tratamento $\mathrm{Tl}(33 \mathrm{kPa})$} \\
\hline $11 / 06 / 91$ & 29,12 & 36,67 & 29,88 & 30,01 & 29,04 & 27,69 & 17,79 \\
\hline $14 / 06 / 91$ & 24,67 & 22,21 & 28.64 & 29,76 & 29,04 & 28,31 & 12,97 \\
\hline $17 / 06 / 91$ & 24,30 & 21,22 & 27,41 & 29,14 & 29,41 & 28,68 & 12,53 \\
\hline $19 / 06 / 91$ & 36,78 & 38,27 & 28.89 & 29,14 & 28,42 & 27,69 & 17,28 \\
\hline $24 / 06 / 91$ & 10,59 & 21,84 & 33,21 & 29,64 & 28,79 & 27,69 & 16,1 \\
\hline $26 / 06 / 91$ & 32,09 & 33,58 & 30.74 & 29,02 & 29,04 & 28,31 & 15,52 \\
\hline $29 / 06 / 91$ & 30,60 & 36,67 & 32,35 & 31,00 & 29,65 & 29,92 & 15,96 \\
\hline $02 / 07 / 91$ & 41,97 & 40,99 & 35.07 & 31,62 & 30,64 & 29,92 & 17,71 \\
\hline $05 / 07 / 91$ & 32,09 & 48,16 & 39,39 & 33,47 & 31,51 & 31,40 & 17,9 \\
\hline 09/07/91 & 48,77 & 56,44 & 36.06 & 31,00 & 30.64 & 29,92 & 19,52 \\
\hline $13 / 07 / 91$ & 39,25 & 66,32 & 37,54 & 32,85 & 33,11 & 31,15 & 20,67 \\
\hline $16 / 07 / 91$ & 40,12 & 66,69 & 47,18 & 39.65 & 36,82 & 33,87 & 26,48 \\
\hline $19 / 07 / 91$ & 38,88 & 39,51 & 44,71 & 43,97 & 39,54 & 36,34 & 23,09 \\
\hline $22 / 07 / 91$ & 7,99 & 7,01 & 48,66 & 49,53 & 44,23 & 39,80 & 19,3 \\
\hline $25 / 07 / 91$ & 50,00 & 50,63 & 50,88 & 53,86 & 48,81 & 43,51 & 23,92 \\
\hline $28 / 07 / 91$ & 45,43 & 58,04 & 36,30 & 63,49 & 55,36 & 49,32 & 25,07 \\
\hline $31 / 07 / 91$ & 51,24 & 68,17 & 68,43 & 70,91 & 62,77 & 56,11 & 26,56 \\
\hline $03 / 08 / 91$ & 34,31 & 68,79 & 54,59 & 60,65 & 66,48 & 62,04 & 25,92 \\
\hline $06 / 09 / 91$ & 46,67 & 62,98 & 62,87 & 63,49 & 56,84 & 58,34 & 25,49 \\
\hline $09 / 08 / 91$ & 39,38 & 50,88 & 68,18 & 73,38 & 68,95 & 65,75 & 24,09 \\
\hline $12 / 08 / 91$ & 47,90 & 59,28 & 69,66 & 72,39 & 70,43 & 66,99 & 26,05 \\
\hline $15 / 08 / 91$ & 38,02 & 30,86 & 71,52 & 74,86 & 72,65 & 69,46 & 24,14 \\
\hline $18 / 08 / 91$ & 45,06 & 57,05 & 71,89 & 64,36 & 73,89 & 70,69 & 25,98 \\
\hline $21 / 08 / 91$ & 45,68 & 39,51 & 71,89 & 74,61 & 72,90 & 33,87 & 24,75 \\
\hline $24 / 08 / 91$ & 30,11 & 25,67 & 70,90 & 75,60 & 73,52 & 70,94 & 21,54 \\
\hline $28 / 08 / 91$ & 48,15 & 44,45 & 72,75 & 74,86 & 70,43 & 70,69 & 25,37 \\
\hline Mínimo: & 7,99 & 7,01 & 27,41 & 29,02 & 28,42 & 27,69 & 12,53 \\
\hline Máximo: & 51,24 & 68,79 & 72,75 & 75,60 & 73,89 & 70,94 & 26,56 \\
\hline Média: & 36,89 & 44,30 & 48,83 & 49,70 & 47,80 & 44,17 & 21,22 \\
\hline Desvio padrão: & 11,25 & 16,85 & 17,06 & 18,96 & 18,45 & 17,01 & 4,48 \\
\hline Lâm. ap. $(\mathrm{mm})$ : & - & - & - & - & - & - & 551,7 \\
\hline Núm. de irrigações & - & - & - & - & $=$ & - & 26 \\
\hline Lâm. inicial (mm) & - & - & - & - & - & - & 50 \\
\hline Precipitação (mm) & - & - & - & $=$ & - & - & 0 \\
\hline Lâmina total (mm) & - & - & - & - & - & - & 601,70 \\
\hline
\end{tabular}


Tabela 23 - Continuação.

\begin{tabular}{|c|c|c|c|c|c|c|c|}
\hline \multirow[t]{2}{*}{ Dia/mês/ano } & \multicolumn{6}{|c|}{ Profundidade dos tensiômetros $(\mathrm{cm})$} & \multirow{2}{*}{$\begin{array}{r}\text { Lâminas } \\
(\mathrm{mm})\end{array}$} \\
\hline & 10 & 20 & 30 & 40 & 60 & 80 & \\
\hline \multicolumn{8}{|c|}{ Tratamento T2 (50 kPa) } \\
\hline $11 / 06 / 91$ & 46,91 & 30,86 & 28,89 & 27,66 & 24,71 & 27,08 & 16,18 \\
\hline $16 / 06 / 91$ & 57,54 & 42,60 & 34,45 & 29,52 & 26,32 & 27,20 & 18,87 \\
\hline $20 / 06 / 91$ & 54,95 & 49,64 & 37,29 & 30,13 & 27,18 & 27,69 & 21,75 \\
\hline $24 / 06 / 91$ & 52,10 & 49,89 & 35,07 & 30,38 & 27,18 & 27,69 & 19,24 \\
\hline $28 / 06 / 91$ & 59,02 & 57,05 & 40,01 & 32,23 & 28,42 & 29,55 & 20,2 \\
\hline $02 / 07 / 91$ & 47,64 & 65,46 & 48,66 & 36,31 & 34,60 & 31,40 & 22.1 \\
\hline $06 / 07 / 91$ & 56,43 & 67,93 & 51,13 & 37,79 & 32,13 & 32,64 & 26,27 \\
\hline $10 / 07 / 91$ & 50,25 & 54,34 & 55,46 & 42,12 & 33,36 & 33,87 & 25,77 \\
\hline $14 / 07 / 91$ & 45,68 & 55,57 & 59,53 & 42,49 & 33,36 & 36,96 & 27,21 \\
\hline $17 / 07 / 91$ & 66,07 & 63,85 & 65,71 & 47,43 & 35,83 & 41,04 & 23,47 \\
\hline $22 / 07 / 91$ & 46,91 & 37,28 & 37,29 & 36,56 & 33,11 & 45,98 & 21,59 \\
\hline $25 / 07 / 91$ & 64,46 & 46,80 & 49,52 & 43,72 & 37,69 & 48,70 & 23,68 \\
\hline $28 / 07 / 91$ & 64,46 & 51,49 & 54,84 & 48,67 & 39,54 & 52,16 & 24,65 \\
\hline $01 / 08 / 91$ & 50,87 & 38,52 & 68,18 & 58,55 & 45,72 & 60,44 & 25,33 \\
\hline $04 / 08 / 91$ & 64,21 & 48,16 & 70,65 & 64,36 & 50,66 & 64,76 & 26,01 \\
\hline $06 / 09 / 91$ & 55,56 & 37,04 & 70,65 & 64,73 & 51,90 & 66,61 & 24,7 \\
\hline $09 / 08 / 91$ & 57,79 & 39,51 & 50,88 & 64,98 & 52,51 & 67,23 & 24,9 \\
\hline $12 / 08 / 91$ & 69,15 & 39,76 & 47,42 & 63,49 & 54,37 & 67,85 & 24,34 \\
\hline $15 / 08 / 91$ & 50,62 & 30,86 & 38,77 & 63,49 & 57,46 & 69,46 & 21,78 \\
\hline $18 / 08 / 91$ & 54,33 & 32,34 & 38,77 & 61,02 & 60,30 & 69,46 & 22,07 \\
\hline $21 / 08 / 91$ & 67,92 & 49,02 & 54,84 & 64,98 & 54,98 & 69,46 & 25,52 \\
\hline $25 / 08 / 91$ & 54,95 & 25,92 & 39,76 & 64,73 & 56,84 & 70,32 & 21,46 \\
\hline $29 / 08 / 91$ & 60,51 & 34.57 & 58,30 & 66,21 & 57,83 & 69,46 & 24,21 \\
\hline Mínimo: & 45,68 & 25,92 & 28,89 & 27,66 & 24,71 & 27,08 & 16,18 \\
\hline Máximo: & 69,15 & 67,93 & 70,65 & 66,21 & 60,30 & 70,32 & 27,21 \\
\hline Média: & 56,45 & 45,58 & 49,40 & 48,76 & 41,56 & 49,43 & 23,10 \\
\hline Desvio padrão: & 7,10 & 11,71 & 12,36 & 14,42 & 12,19 & 17,55 & 2,73 \\
\hline Lâm. ap. (mm): & - & - & - & - & - & - & 531,3 \\
\hline Núm. de irrigações & - & - & - & - & - & - & 23 \\
\hline Lâm. inicial (mm) & - & - & - & - & - & - & 50 \\
\hline Precipitação (mm) & $=$ & - & - & - & - & - & 0 \\
\hline Lâmina total (mm) & - & - & - & - & - & - & 581,30 \\
\hline
\end{tabular}


Tabela 23 - Continuação.

\begin{tabular}{|c|c|c|c|c|c|c|c|}
\hline \multirow[t]{2}{*}{ Dia/mês/ano } & \multicolumn{6}{|c|}{ Profundidade dos tensiômetros $(\mathrm{cm})$} & \multirow{2}{*}{$\begin{array}{r}\text { Lâminas } \\
(\mathrm{mm})\end{array}$} \\
\hline & 10 & 20 & 30 & 40 & 60 & 80 & \\
\hline \multicolumn{8}{|c|}{ Tratamento $\mathrm{T} 3(70 \mathrm{kPa})$} \\
\hline $12 / 06 / 91$ & 48,77 & 35,43 & 30,74 & 29,14 & 29,04 & 26,21 & 17,21 \\
\hline $19 / 06 / 91$ & 70,39 & 52,11 & 35,07 & 31,62 & 29,04 & 26,46 & 20,59 \\
\hline $24 / 06 / 91$ & 65,82 & 43,21 & 35,44 & 31,37 & 29,65 & 26,46 & 19,71 \\
\hline $29 / 06 / 91$ & 67,30 & 45,69 & 34,82 & 31,37 & 29,04 & 28.31 & 19,35 \\
\hline 03/07/91 & 74,10 & 58,91 & 33,46 & 33,47 & 30,27 & 28,93 & 20,38 \\
\hline $07 / 07 / 91$ & 73,23 & 24,06 & 45,20 & 35,32 & 31,88 & 28,93 & 18,57 \\
\hline $11 / 07 / 91$ & 73,85 & 65,70 & 49,89 & 37,18 & 33,36 & 30,78 & 22,31 \\
\hline $15 / 07 / 91$ & 73,85 & 65,70 & 48,41 & 32,60 & 32,13 & 29,92 & 26,13 \\
\hline $20 / 07 / 91$ & 75,33 & 67,31 & 27,65 & 21,73 & 22,24 & 26,46 & 20,56 \\
\hline $24 / 07 / 91$ & 72,61 & 65,46 & 44,71 & 31,37 & 29,41 & 29,92 & 23,48 \\
\hline $30 / 07 / 91$ & 75,95 & 23,45 & 58,54 & 42,74 & 39,54 & 35,97 & 21,9 \\
\hline 03/08/91 & 74,71 & 66,69 & 75,60 & 60,65 & 54,98 & 43,51 & 27,43 \\
\hline $07 / 08 / 91$ & 69,77 & 73,12 & 73,12 & 66,83 & 64,00 & 42,52 & 27,69 \\
\hline $11 / 08 / 91$ & 71,38 & 73,12 & 77,70 & 66,83 & 71,05 & 47,46 & 27,91 \\
\hline $14 / 08 / 91$ & 61,12 & 67,93 & 75,22 & 72,14 & 73,52 & 23,99 & 27,4 \\
\hline $18 / 07 / 91$ & 68,91 & 24,93 & 75,84 & 71,77 & 71,67 & 53,64 & 28,11 \\
\hline $22 / 08 / 91$ & 54,33 & 74,35 & 72,14 & 73,01 & 75,37 & 13,85 & 27,21 \\
\hline $27 / 08 / 91$ & 75,33 & 78,06 & 69,42 & 66,21 & 72,28 & 14,10 & 27,9 \\
\hline Mínimo: & 48,77 & 23,45 & 27,65 & 21,73 & 22,24 & 13,85 & 17,21 \\
\hline Máximo: & 75,95 & 78,06 & 77,70 & 73,01 & 75,37 & 53,64 & 28,11 \\
\hline Média: & 69,26 & 55,85 & 53,50 & 46,41 & 45,47 & 30,97 & 23,55 \\
\hline Desvio padrão: & 7,56 & 18,52 & 18,54 & 18,51 & 20,01 & 10,37 & 3,87 \\
\hline Lâm. ap. $(\mathrm{mm})$ : & - & - & - & - & - & - & 423,84 \\
\hline Núm. de irrigações & - & - & - & - & - & - & 18 \\
\hline Lâm. inicial (mm) & - & - & - & - & - & - & 50 \\
\hline Precipitação (mm) & $=$ & - & - & - & - & - & 0 \\
\hline Lâmina total (mm) & - & - & - & - & - & - & 473.84 \\
\hline
\end{tabular}


Tabela 23 - Continuação.

\begin{tabular}{|c|c|c|c|c|c|c|c|}
\hline \multirow[t]{2}{*}{ Dia/mês/ano } & \multicolumn{6}{|c|}{ Profundidade dos tensiômetros $(\mathrm{cm})$} & \multirow{2}{*}{$\begin{array}{r}\text { Lâminas } \\
(\mathrm{mm})\end{array}$} \\
\hline & 10 & 20 & 30 & 40 & 60 & 80 & \\
\hline \multicolumn{8}{|c|}{ Tratamento T4 $(100 \mathrm{kPa})$} \\
\hline $14 / 06 / 91$ & 123,23 & 77,81 & 67,36 & 88,82 & - & - & 22,21 \\
\hline $23 / 06 / 91$ & 131,28 & 94,69 & 77,19 & 82,01 & - & - & 29,27 \\
\hline $02 / 07 / 91$ & 131,28 & 82,01 & 84,91 & 87,72 & - & - & 20,57 \\
\hline $08 / 07 / 91$ & 153,23 & 127,31 & 119,03 & 105,58 & - & - & 21,57 \\
\hline $13 / 07 / 91$ & 146,23 & 163,25 & 127,31 & 110,22 & - & - & 32,23 \\
\hline $17 / 07 / 91$ & 123,23 & 119,03 & 131,28 & 119,03 & - & - & 34,72 \\
\hline $22 / 07 / 91$ & 131,28 & 92,06 & 105,58 & 89,91 & - & - & 24,96 \\
\hline $27 / 07 / 91$ & 127,31 & 90,46 & 100,76 & 95,73 & - & - & 34,04 \\
\hline $02 / 08 / 91$ & 142,62 & 95,73 & 110,22 & 114,70 & - & - & 33,91 \\
\hline $08 / 08 / 91$ & 159,97 & 119,03 & 114,70 & 201,64 & - & - & 35,52 \\
\hline $12 / 08 / 91$ & 135,15 & 123,23 & 127,31 & 227,33 & - & - & 32,65 \\
\hline $16 / 08 / 91$ & 149,77 & 119,03 & 127,31 & 272,38 & - & - & 31,97 \\
\hline $21 / 08 / 91$ & 153,23 & 114,70 & 90,46 & 292,65 & - & - & 34,05 \\
\hline $26 / 08 / 91$ & 149.77 & 119.03 & 87,72 & 302.34 & - & - & 31,33 \\
\hline Minimo: & 123,23 & 77,81 & 67,36 & 82,01 & - & - & 20,57 \\
\hline Máximo: & 159,97 & 163,25 & 131,28 & 302,34 & - & - & 35,52 \\
\hline Média: & 139,83 & 109,81 & 105,08 & 156,43 & - & - & 29,93 \\
\hline Desvio padrão: & 12,28 & 22,56 & 20,80 & 83,74 & - & - & 5,30 \\
\hline Lâm. ap. (mm): & - & - & - & - & - & - & 419,00 \\
\hline Núm. de irrigações & - & - & - & - & - & - & 14 \\
\hline Lâm. inicial (mm) & - & - & - & - & - & - & 50 \\
\hline Precipitação (mm) & - & - & - & $=$ & - & - & 0 \\
\hline Lâmina total (mm) & - & - & - & - & - & - & 469,00 \\
\hline
\end{tabular}

Tratamento T5 (500 kPa)

\begin{tabular}{lccccccr}
\hline $20 / 06 / 91$ & 676,09 & 90,46 & 80,83 & 84,91 & - & - & 41,35 \\
$02 / 07 / 91$ & 452,49 & 172,75 & 131,28 & 95,73 & - & - & 38,9 \\
$11 / 07 / 91$ & 320,96 & 309,90 & 288,69 & 163,25 & - & - & 42,92 \\
$22 / 07 / 91$ & 465,83 & 227,33 & 234,56 & 255,19 & - & - & 45,12 \\
$30 / 07 / 91$ & 504,02 & 452,49 & 539,86 & 491,57 & - & - & 47,39 \\
$06 / 08 / 91$ & 363,90 & 227,33 & 478,85 & 551,36 & - & - & 43,85 \\
$12 / 08 / 91$ & 424,74 & 424,74 & 616,44 & 636,86 & - & - & 42,49 \\
\hline Mínimo: & 320,96 & 90,46 & 80,83 & 84,91 & - & - & 38,90 \\
Máximo: & 676,09 & 452,49 & 616,44 & 636,86 & - & - & 47,39 \\
Média: & 458,29 & 272,14 & 338,65 & 325,55 & - & - & 43,15 \\
Desvio padrão: & 114,39 & 131,75 & 208,21 & 230,03 & - & - & 2,71 \\
Lâm. ap. (mm): & - & - & - & - & - & - & 302,02 \\
Núm. de irrigações & - & - & - & - & - & - & 7 \\
Lâm. inicial (mm) & - & - & - & - & - & - & 50 \\
Precipitação (mm) & - & - & - & - & - & - & 0 \\
Lâmina total (mm) & - & - & - & - & - & - & 352,02 \\
\hline
\end{tabular}

Continua 
Tabela 23 - Continuação.

\begin{tabular}{|c|c|c|c|c|c|c|c|}
\hline \multirow[t]{2}{*}{ Dia/mês/ano } & \multicolumn{6}{|c|}{ Profundidade dos tensiômetros $(\mathrm{cm})$} & \multirow{2}{*}{$\begin{array}{r}\text { Lâminas } \\
\text { (mm) }\end{array}$} \\
\hline & 10 & 20 & 30 & 40 & 60 & 80 & \\
\hline \multicolumn{8}{|c|}{ Tratamento T6 $(1000 \mathrm{kPa})$} \\
\hline $23 / 06 / 91$ & 1001,87 & 322,77 & 114,70 & 77,81 & - & - & 33,75 \\
\hline $05 / 07 / 91$ & 1074,57 & 606,02 & 452,49 & 93,12 & - & - & 33,67 \\
\hline $15 / 07 / 91$ & 938,82 & 584,68 & 329,93 & 196,16 & - & - & 45,41 \\
\hline $27 / 07 / 91$ & 1008,66 & 606,02 & 424,74 & 217,37 & - & - & 42,08 \\
\hline $05 / 08 / 91$ & 938,82 & 783,52 & 606,02 & 516,20 & - & - & 43,49 \\
\hline $14 / 08 / 91$ & 1008,66 & 740,39 & 646,86 & 410,26 & - & - & 43,26 \\
\hline $23 / 08 / 91$ & 960,23 & 685,59 & 528,14 & 465,83 & $=$ & - & 43,13 \\
\hline Mínimo: & 938,82 & 322,77 & 114,70 & 77,81 & - & - & 33,67 \\
\hline Máximo: & 1074,57 & 783,52 & 646,86 & 516,20 & - & - & 45,41 \\
\hline Média: & 990,23 & 618,43 & 443,27 & 282,39 & - & - & 40,68 \\
\hline Desvio padrão: & 48,50 & 150,28 & 180.91 & 179,82 & - & - & 4,87 \\
\hline Lâm. ap. $(\mathrm{mm})$ : & - & - & - & - & - & - & 284,79 \\
\hline Núm. de irrigações & - & - & - & - & - & - & 7 \\
\hline Lâm. inicial (mm) & - & - & - & - & - & - & 50 \\
\hline Precipitação (mm) & - & - & - & - & - & - & 0 \\
\hline Lâmina total (mm) & - & - & - & - & - & - & 334,79 \\
\hline
\end{tabular}




\section{A N E X O III}

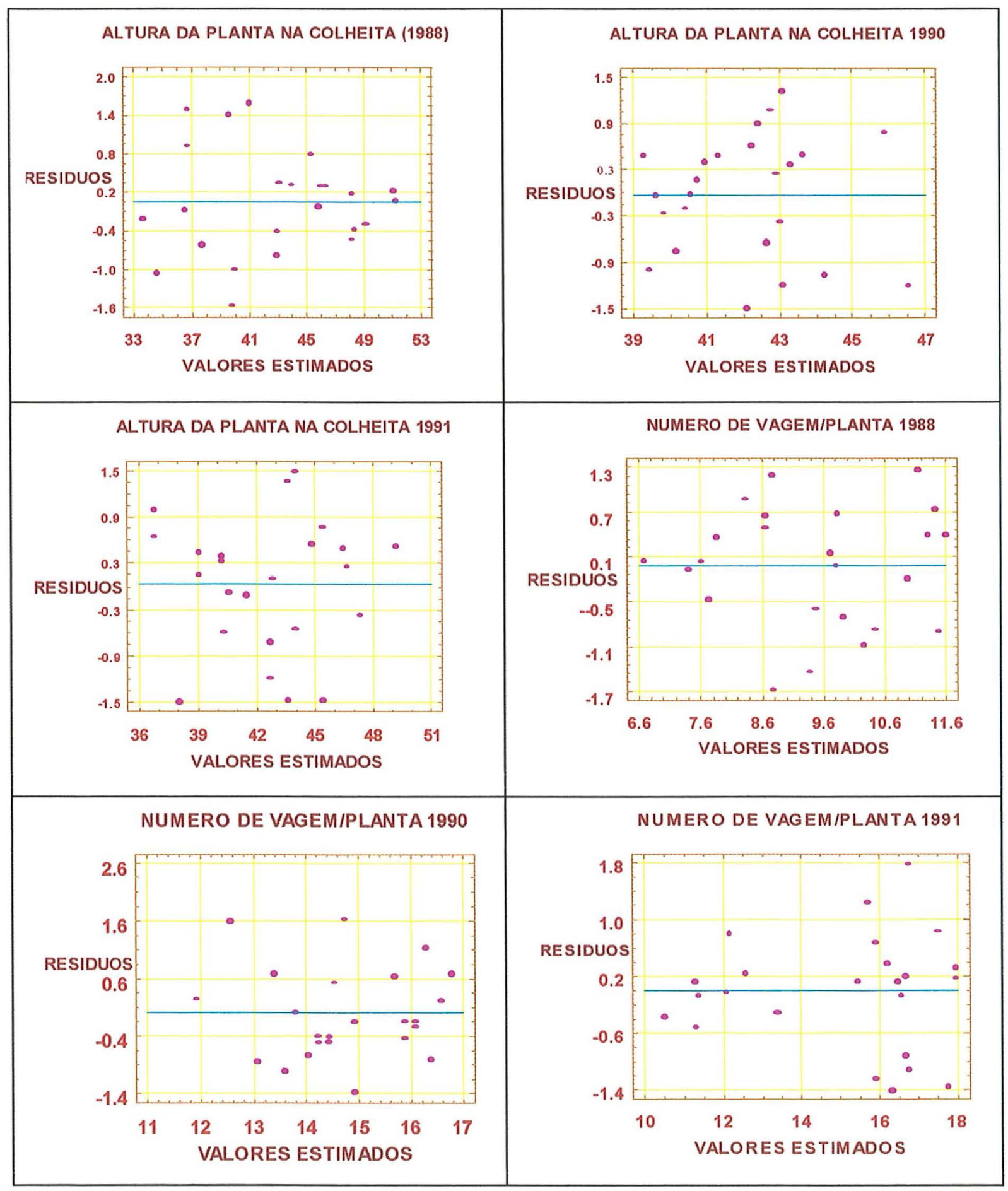

Figura 22 - Análise gráfica de resíduos para a altura de planta na colheita e número de vagens por planta do feijoeiro nos anos de 1988, 1990 e 1991. 


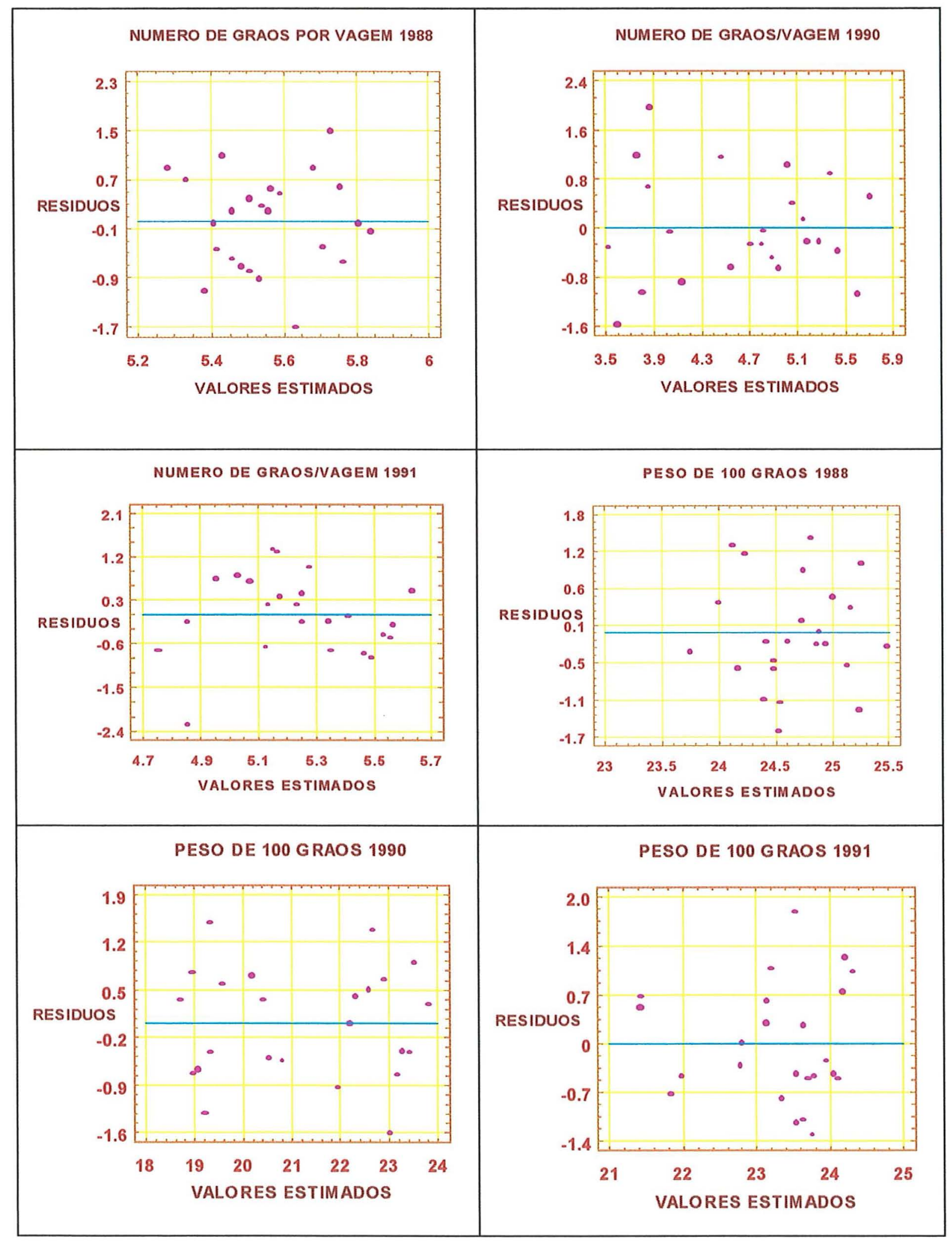

Figura 23 - Análise gráfica de resíduos para o número de grãos por vagem e peso de 100 grãos do feijoeiro nos anos de 1988, 1990 e 1991. 


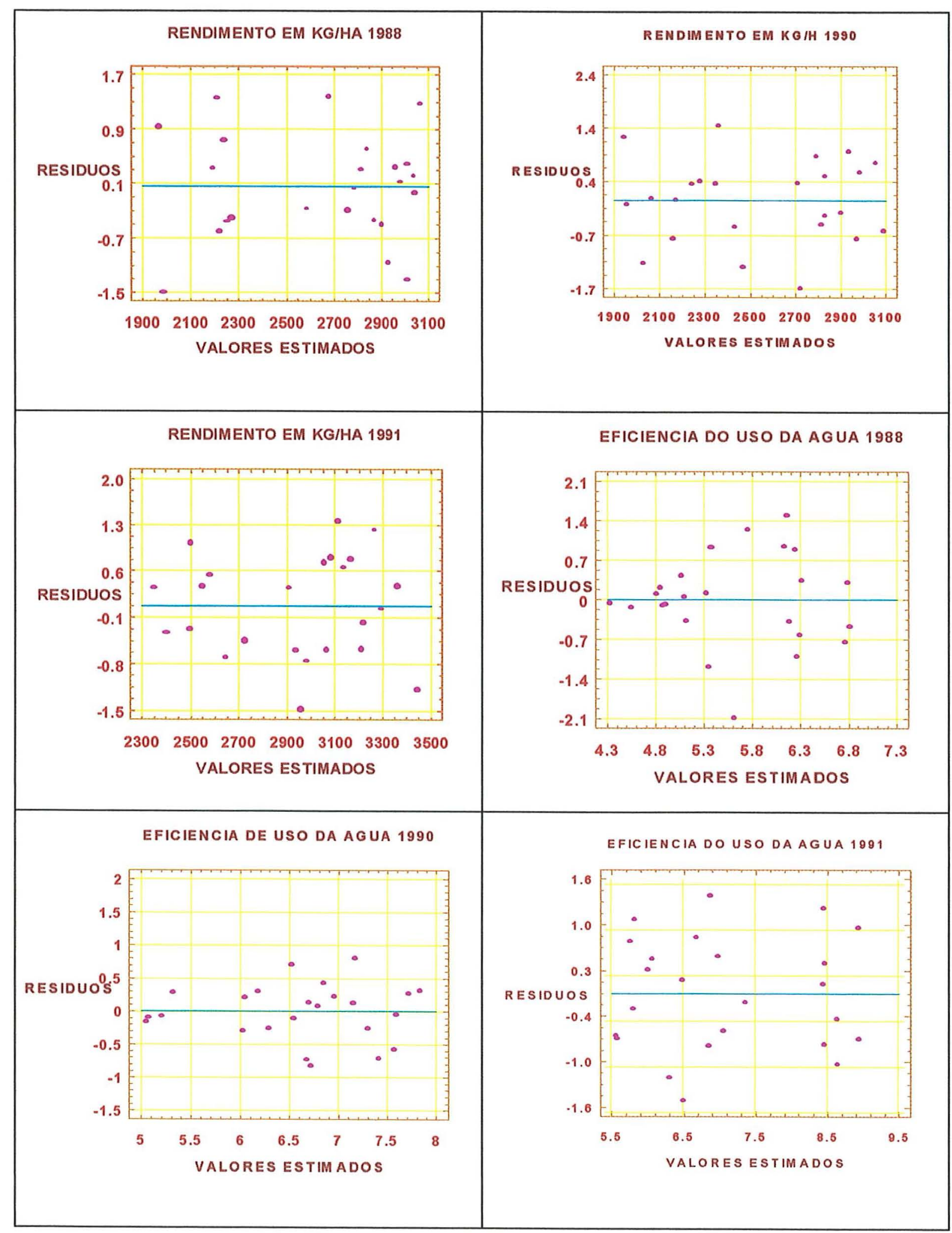

Figura 24 - Análise gráfica de resíduos para rendimento de grãos e eficiência de uso da água do feijoeiro nos anos de 1988, 1990 e 1991. 


\section{A N E X O III}

Tabela 24 - Diagramas de ramos e folhas para as variáveis estudadas

\begin{tabular}{|c|c|c|}
\hline $\begin{array}{l}\text { ALPL- } 88: \text { unidade }=1 \\
1 / 2 \text { representa } 12\end{array}$ & $\begin{array}{l}\text { ALPL-90: unidade }=0.1 \\
1 \mid 2 \text { representa } 1.2\end{array}$ & $\begin{array}{l}\text { ALPL-91: unidade }=1 \\
1 \mid 2 \text { representa } 12\end{array}$ \\
\hline $\begin{array}{rl}2 & 20 \mid 79 \\
5 & 3 * 1123 \\
8 & 30 \mid 579 \\
10 & 4 * 124 \\
(10) & 4015555667789 \\
4 & 5 \star 10112\end{array}$ & $\begin{array}{cl}1 & 36 \mid 2 \\
3 & 37 \mid 28 \\
3 & 38 \mid \\
7 & 39 \mid 0268 \\
10 & 40 \mid 668 \\
(3) & 41 \mid 048 \\
11 & 42 \mid 46 \\
9 & 43 \mid 08 \\
7 & 44 \mid 46 \\
5 & 45 \mid 45 \\
3 & 46 \mid 4 \\
2 & 47 \mid 6 \\
1 & 48 \mid 6\end{array}$ & $\begin{array}{l}3 \mathrm{~T} \mid 3 \\
3 \mathrm{~F} \mid \\
3 \mathrm{~S} \mid \\
30 \mid 88889 \\
4 \star 100000111 \\
4 \mathrm{~T} \mid 23 \\
4 \mathrm{E} \mid \\
4 \mathrm{~S} \mid 6677 \\
40 \mid 888 \\
5 \star 10\end{array}$ \\
\hline 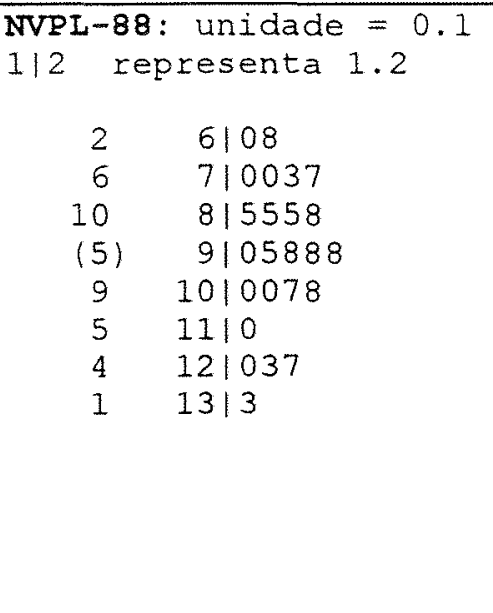 & 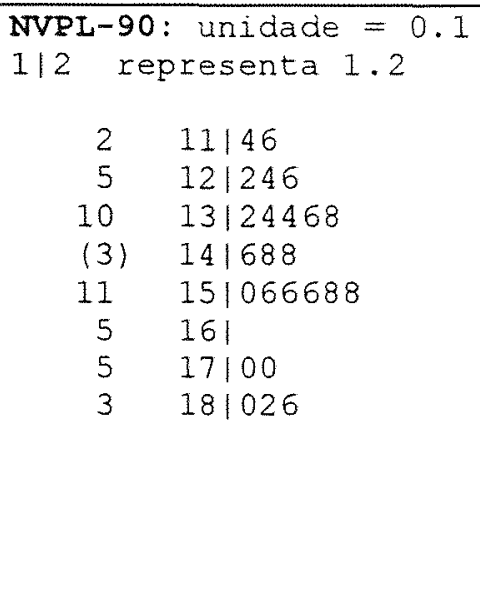 & $\begin{array}{l}\text { NVPL-91: unidade }=0.1 \\
1 \mid 2 \text { representa } 1.2 \\
\begin{array}{cl}1 & 9 \mid 6 \\
2 & 10 \mid 0 \\
4 & 11 \mid 26 \\
8 & 12 \mid 0688 \\
9 & 13 \mid 2 \\
(4) & 14 \mid 0244 \\
11 & 15 \mid 8 \\
10 & 16 \mid 48 \\
8 & 17 \mid 226 \\
5 & 18 \mid 488 \\
2 & 19 \mid 6 \\
1 & 201 \\
1 & 2112\end{array}\end{array}$ \\
\hline $\begin{array}{ll}\text { NGV-88: unidade }=0.01 \\
1 / 2 \text { representa } 0.12 \\
\begin{array}{rl}1 & 5110 \\
2 & 5210 \\
7 & 53100000 \\
8 & 5410 \\
11 & 551000 \\
(5) & 56 \mid 00000 \\
8 & 57 \mid 000 \\
5 & 58100 \\
3 & 59100 \\
1 & 601 \\
1 & 6110\end{array}\end{array}$ & \begin{tabular}{cl}
\multicolumn{2}{l}{ NGV-90: unidade $=0.1$} \\
I12 representa 1.2 \\
3 & $3 * 1044$ \\
4 & 3018 \\
8 & $4 * 10123$ \\
$(7)$ & 4016677789 \\
9 & $5 * 11222234$ \\
2 & 50179
\end{tabular} & $\begin{array}{l}\text { NGV-91: unidade }=0.01 \\
112 \text { representa } 0.12 \\
\text { Lo/410, 450,480 } \\
\text { (respectivamente: B2T2, } \\
\text { B2T6, B4T6) } \\
4 \quad 4910 \\
4 \quad 501 \\
5 \quad 5110 \\
10 \quad 52100000 \\
\text { (5) } 53100000 \\
95410000 \\
5 \quad 5510 \\
4561000 \\
\text { HI } 1580\end{array}$ \\
\hline
\end{tabular}


Tabela 24 - Continuação.

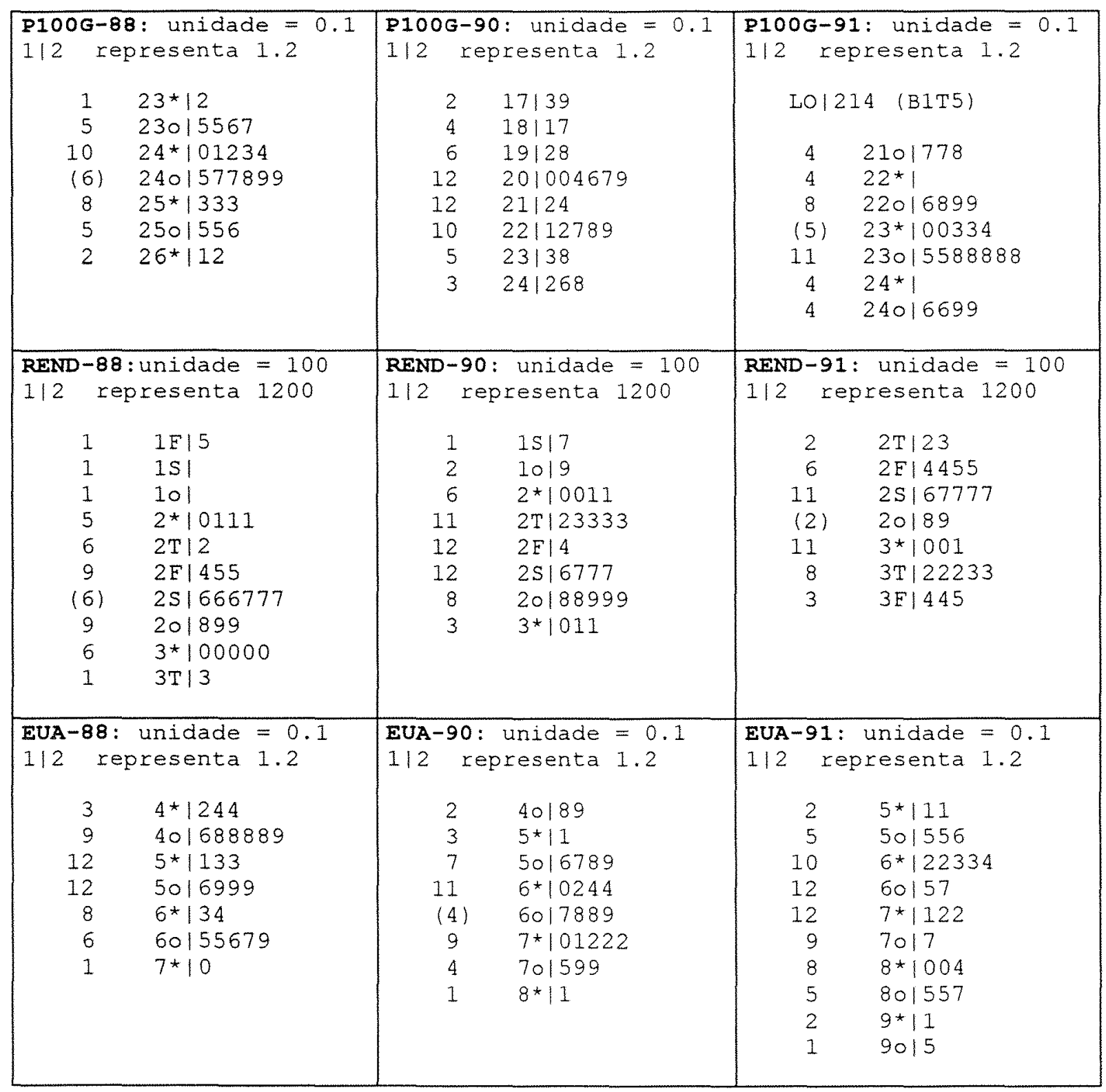

Legenda:

ALPL:

NVPL:

NGV:

P100G:

REND:

EUA:
Altura de planta

Número de vagem por planta

Número de grãos por vagem

Peso de 100 grãos

Rendimento de grãos

Eficiência de uso da água 